\title{
The MACC-II 2007-2008 reanalysis: atmospheric dust evaluation and characterization over northern Africa and the Middle East
}

\author{
E. Cuevas ${ }^{1}$, C. Camino ${ }^{1}$, A. Benedetti ${ }^{2}$, S. Basart ${ }^{3}$, E. Terradellas ${ }^{4}$, J. M. Baldasano ${ }^{3,5}$, J. J. Morcrette ${ }^{2}$, \\ B. Marticorena $^{6}$, P. Goloub ${ }^{7}$, A. Mortier $^{7}$, A. Berjón ${ }^{1}$, Y. Hernández ${ }^{1}$, M. Gil-Ojeda ${ }^{8}$, and M. Schulz ${ }^{9}$ \\ ${ }^{1}$ Izaña Atmospheric Research Center, AEMET, Santa Cruz de Tenerife, Spain \\ ${ }^{2}$ European Centre for Medium-Range Weather Forecasts, ECMWF, Reading, UK \\ ${ }^{3}$ Earth Sciences Department, Barcelona Supercomputing Center, Barcelona, Spain \\ ${ }^{4}$ SDS-WAS Regional Center, AEMET, Barcelona, Spain \\ ${ }^{5}$ Environmental Modelling Laboratory, Technical University of Catalonia, Barcelona, Spain \\ ${ }^{6}$ LISA, UMR7583, CNRS, Universités Paris Est-Paris Diderot, Créteil, France \\ ${ }^{7}$ Laboratoire d'Optique Atmosphérique, Université Lille 1, Lille, France \\ ${ }^{8}$ Atmospheric Research and Instrumentation Branch, INTA, Madrid, Spain \\ ${ }^{9}$ Climate and Air Pollution Section, Norwegian Meteorological Institute, Oslo, Norway
}

Correspondence to: E. Cuevas (ecuevasa@aemet.es)

Received: 27 June 2014 - Published in Atmos. Chem. Phys. Discuss.: 11 November 2014

Revised: 24 March 2015 - Accepted: 26 March 2015 - Published: 16 April 2015

\begin{abstract}
In the present work, atmospheric mineral dust from a MACC-II short reanalysis run for 2 years (20072008) has been evaluated over northern Africa and the Middle East using satellite aerosol products (from MISR, MODIS and OMI satellite sensors), ground-based AERONET data, in situ $\mathrm{PM}_{10}$ concentrations from AMMA, and extinction vertical profiles from two ground-based lidars and CALIOP satellite-based lidar. The MACC-II aerosol optical depth (AOD) spatial and temporal (seasonal and interannual) variability shows good agreement with those provided by satellite sensors. The capability of the model to reproduce the AOD, Angström exponent (AE) and dust optical depth (DOD) from daily to seasonal time-scale is quantified over 26 AERONET stations located in eight geographically distinct regions by using statistical parameters. Overall DOD seasonal variation is fairly well simulated by MACC-II in all regions, although the correlation is significantly higher in dust transport regions than in dust source regions. The ability of MACC-II in reproducing dust vertical profiles has been assessed by comparing seasonal averaged extinction vertical profiles simulated by MACC-II under dust conditions with corresponding extinction profiles obtained with lidar instruments at M'Bour and Santa Cruz de Tenerife, and with CALIOP. We find a good agreement in dust layers
\end{abstract}

structures and averaged extinction vertical profiles between MACC-II, the lidars and CALIOP above the marine boundary layer from 1 to $6 \mathrm{~km}$. Surface dust daily mean concentrations from MACC-II reanalysis has been evaluated with daily averaged $\mathrm{PM}_{10}$ at three monitoring stations of the Sahelian Dust Transect. MACC-II correctly reproduces daily to interannual surface dust concentration variability, although it underestimates daily and monthly means all year long, especially in winter and early spring (dry season). MACC-II reproduces well the dust variability recorded along the station transect which reflects the variability in dust emission by different Saharan sources, but fails in reproducing the sporadic and very strong dust events associated to mesoscale convective systems during the wet season.

\section{Introduction}

Mineral dust has significant impacts in many regions of the world. Airborne mineral dust can have numerous repercussions on human health, such us allergies, respiratory diseases and eye infections (WHO, 2006; Giannadaki et al., 2014); it is also linked to epidemics of deadly meningitis in the region known as the meningitis belt (Sultan, 2005; Thomson et al., 
2006; Pérez García-Pando et al., 2014). Increased airborne mineral dust reduces visibility (Wang et al., 2008) with consequent problems in road and air transportation, while dust storms have negative impacts on agriculture causing loss of crop and livestock (Stefanski and Sivakumar, 2009). Desert dust deposition also influences the biogeochemical cycles of both oceanic and terrestrial ecosystems (Okin et al., 2004; Jickells et al., 2005; Mahowald et al., 2005, 2010; Schulz et al., 2012) via for example the release of iron from dust into seawater (Nickovic et al., 2013). Indeed, due to the many connections with the Earth's systems, mineral dust can also impact the carbon cycle and atmospheric $\mathrm{CO}_{2}$ (Jickells et al., 2005; Hamza et al., 2011).

Mineral dust also has a significant impact on the Earth radiative budget (IPCC, 2013), through both direct and indirect effects. The radiative forcing resulting from large changes in the global dust cycle is thought to have played an important role in amplifying past climate changes (Jansen et al., 2007; Abbot and Halevy, 2010). Indirect effects of dust on cloud formation and precipitation rate can provide additional changes in the Earth's radiation balance and hydrological cycle. Several studies have observed that mineral dust generates large concentrations of cloud condensation nuclei (CCN) and ice nuclei (IN) (Vali, 1985; Klein et al., 2010; Hoose and Möhler, 2012). Dust particles acting both as CCN and IN modify the cloud microphysical and macrophysical properties, namely droplet size, cloud albedo, cloud cover, vertical extent and lifetime (Hansen et al., 1997; Heymsfield et al., 2009; Cziczo et al., 2013).

The Sahara and its margins contribute to more than half of the global dust emissions (Huneeus et al., 2011; IPCC, 2013). Airborne African dust has a complex relationship with climate, its transport being strongly controlled in turn by climate variability (Prospero and Nees, 1986; Moulin et al., 1997; Ginoux et al., 2004; Mahowald et al., 2010; AlonsoPérez et al., 2011; Rodríguez et al., 2014) and changes in the land surface conditions (Middleton and Goudie, 2001; Moulin and Chiapello, 2004). These climatological studies may be further extended with new and improved model simulations for long-term periods.

Dust modelling is essential, not only to have a powerful tool to predict the global or regional dust budget and its interactions in the climate-weather system, but also to complement remote sensing and in situ observations and to understand the processes involved in the dust cycle. Several experimental and operational dust forecast systems have been developed in the recent years, including global models such as the Navy Aerosol Analysis and Prediction System (NAAPS; Westphal et al., 2009), the interactive chemistry and aerosol model (INCA/LMDz; Hauglustaine et al., 2004) and the aerosol model at the European Centre for Medium-range Weather Forecasts (MACC-ECMWF; Morcrette et al., 2009; Benedetti et al., 2009); and European regional models such as BSC-DREAM8b (Nickovic et al., 2001; Pérez et al., 2006a, b; Basart et al., 2012), CHIMERE
(Menut, 2008; Schmechtig et al., 2011), and NMMB/BSCDust (Pérez et al., 2011; Haustein et al., 2012). These models are participating in the World Meteorological Organization (WMO) Sand and Dust Storm Warning Advisory and Assessment System (SDS-WAS), Regional Center for Northern Africa, the Middle East and Europe (http://sds-was.aemet. es/). The centre seeks to achieve comprehensive, coordinated and sustained observations and modelling capabilities of sand and dust storms, in order to improve their monitoring state, increase the understanding of their formation processes, and overall enhance the prediction capabilities of dust models.

Studies comparing and evaluating the temporal (on annual, seasonal and daily basis) and spatial variability of desert dust load and deposition simulated by different models, contribute to determine the degree of uncertainty in estimates of dust emission and transport. They highlight the sources of uncertainty in these estimates, and point to the key foci for future research in order to constrain them (e.g. Tegen, 2003; Kinne et al., 2006; Textor et al., 2006; Huneeus et al., 2011). Dust-related products, such as horizontal visibility, particulate matter concentration, aerosol optical depth (AOD), and extinction vertical profiles will likely be incorporated as added value information in future climate services databases. Long-term dust-related observations and model reanalysis may contribute to understand assessments and plan activities of health and energy communities and to other economic sectors in many regions of the world. For example, comprehensive long-term dust records might help to understand and prevent health problems through epidemiological studies. Dust climatologies might be used to perform feasibility studies of future solar power plants in arid and desert regions.

The present study evaluates and analyses the MACC-II (Monitoring Atmospheric Composition and Climate; Interim Implementation) reanalysis dust simulation for the period 2007-2008 over northern Africa, the Middle East and adjacent regions using ground-based and satellite observations. We clarify that this is not the 10-year MACC reanalysis that is publicly available for the period 2003-2012, but a reanalysis of 2 years implemented specifically for this study. The new MACC-II reanalysis incorporates an improved dust parameterization scheme. Some evaluations from the atmospheric composition MACC reanalysis have been published (e.g. Elguindi et al., 2010; Bellouin et al., 2013; Inness et al., 2013; Cesnulyte et al., 2014), but none of these studies focused specifically on mineral dust products. An important objective of the MACC-II reanalysis evaluation is to examine its ability to reproduce aerosol spatiotemporal variability.

The description of the MACC-II reanalysis is provided in Sect. 2, while Sect. 3 includes the description of the different observational data sets used for the model evaluation. The results of the comparison are shown in Sect. 4. Finally, Sect. 5 summarizes the most important findings of the present study. 


\section{The MACC-II Aerosol prediction system: 2007-2008 aerosol reanalysis}

Starting in 2008, ECMWF has been providing daily aerosol forecasts including dust as part of the EU-funded projects GMES (Global Monitoring for Environment and Security, now COPERNICUS), MACC and MACC-II. A 10-year reanalysis for 2003-2012 has also been completed during the MACC-II project (Inness et al., 2013). A detailed description of the initial implementation of the aerosol modules is given in Morcrette et al. (2009) for the modelling part, and in Benedetti et al. (2009) for the assimilation part. The physical parameterizations for the aerosol processes are modelled after the LOA/LMD-Z model (Boucher et al., 2002; Reddy et al., 2005). However, some modifications to the original schemes were introduced over the years. Some of these modifications are described in Morcrette et al. (2011).

Five types of tropospheric aerosols are considered in the model: sea-salt, dust, organic and black carbon, and sulphate aerosols. Prognostic aerosols of natural origin, such as mineral dust and sea-salt are described using three size bins. For dust, bin limits are at $0.03,0.55,0.9$, and 20 microns while for sea-salt bin limits are at 0.03, 0.5, 5 and $20 \mathrm{mi}-$ crons. Emissions of dust depend on the $10 \mathrm{~m}$ wind, soil moisture, the UV-visible component of the surface albedo and the fraction of land covered by vegetation when the surface is snow-free. A correction to the $10 \mathrm{~m}$ wind to account for gustiness is also included (Morcrette et al., 2008). Sea-salt emissions are diagnosed using a source function based on work by Guelle et al. (2001) and Schulz et al. (2004). In this Laboratoire des Sciences du Climat et de l'Environnement (LSCE)/ECMWF formulation, wet sea-salt mass fluxes at $80 \%$ relative humidity are integrated for the three size bins, merging work by Monahan et al. (1986) and Smith and Harrison (1998) between 2 and $4 \mathrm{~mm}$. Sources for the other aerosol types which are linked to emissions from domestic, industrial, power generation, transport and shipping activities, are taken from the SPEW (Speciated Particulate Emission Wizard), and EDGAR (Emission Database for Global Atmospheric Research) annual or monthly mean climatologies. More details on the sources of these aerosols are given in Dentener et al. (2006). Emissions of organic matter (OM), black-carbon (BC) and $\mathrm{SO}_{2}$ linked to fire emissions are obtained using the Global Fire Assimilation System (GFAS) system based on Moderate Resolution Imaging Spectrometer (MODIS) satellite observations of fire radiative power, as described in Kaiser et al. (2012). The 10-year reanalysis employs GFAS-based fire emissions for 2009-2012 and the GFED3 inventory for 2003-2008 (van der Werf et al., 2010).

Several types of removal processes are considered: dry deposition including the turbulent transfer to the surface, the gravitational settling, and wet deposition including rainout by large-scale and convective precipitation and washout of aerosol particles in and below the clouds. The wet and dry deposition schemes are standard, whereas the sedimentation of aerosols follows closely what was introduced by Tompkins (2005) for the sedimentation of ice particles. Hygroscopic effects are also considered for organic matter and black carbon aerosols.

MODIS Dark Target AOD Collection 5 data at $550 \mathrm{~nm}$ are routinely assimilated in a 4D-Var framework which has been extended to include aerosol total mixing ratio as extra control variable (Benedetti et al., 2009). A variational bias correction for MODIS AOD is also implemented based on the operational set-up for radiances, following the developments by Dee and Uppala (2009). The bias model for the MODIS data consists of a global constant that is adjusted variationally in the minimization based on the first-guess departures. The observation error covariance matrix is assumed to be diagonal, to simplify the problem. The errors are also chosen ad hoc and prescribed as fixed values over land and ocean for the assimilated observations. The aerosol background error covariance matrix used for aerosol analysis was derived using the Parrish and Derber method (also known as the NMC method; Parrish and Derber, 1992) as detailed by Benedetti and Fisher (2007). This method was long used for the definition of the background error statistics for the meteorological variables and is based on the assumption that the forecast differences between the 48 and the $24 \mathrm{~h}$ forecasts are a good statistical proxy to estimate the model background errors.

Following positive changes in the dust parameterization scheme, it was proposed to run a short MACC-II reanalysis for 2 years (2007-2008) with a more recent model version. No additional dust-specific observations were used in this new reanalysis, but only MODIS Dark Target AOD at $550 \mathrm{~nm}$. This run is evaluated in the current paper with special attention to the Sahara-Sahel region where most of the changes implemented had an impact. With respect to the 10year reanalysis, the main changes were

1. a revision of the dust emission potential for the SaharaSahel region, now divided in four sub-regions, as opposed to the single region in the previous version (indicated in Fig. 1)

2. a retuning of the dust emissions

3. a bug-fix for the wet deposition

4. meteorological model changes, including modifications to the cloud scheme with the introduction of prognostic rain and snow variables, improvements to the convection scheme, and retuning of other physical processes parameterizations (orographic gravity wave drag, diffusion, surface roughness, etc.),

5. assimilation changes including snow analysis, improved all-sky microwave assimilation, and assimilation of precipitation from ground-based radar.

It is difficult to quantify the contribution of the individual changes to the differences in the aerosol forecast, but it is 
a)

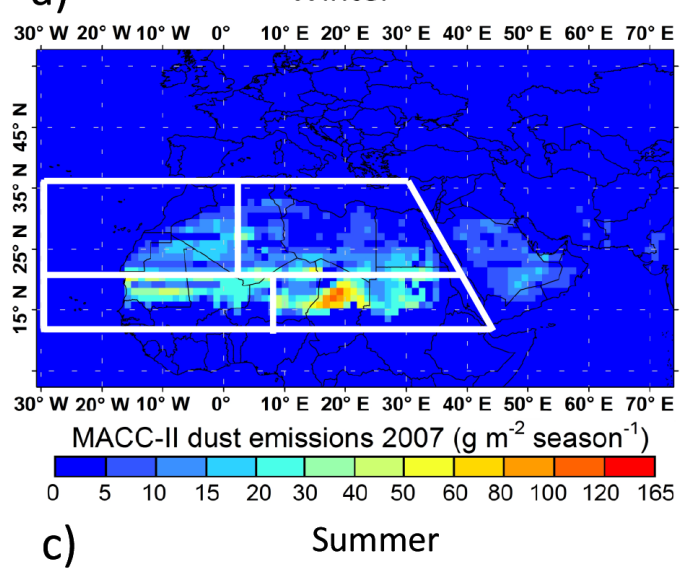

$30^{\circ} \mathrm{W} 20^{\circ} \mathrm{W} 10^{\circ} \mathrm{W} \quad 0^{\circ} \quad 10^{\circ} \mathrm{E} 20^{\circ} \mathrm{E} 30^{\circ} \mathrm{E} 40^{\circ} \mathrm{E} 50^{\circ} \mathrm{E} 60^{\circ} \mathrm{E} 70^{\circ} \mathrm{E}$

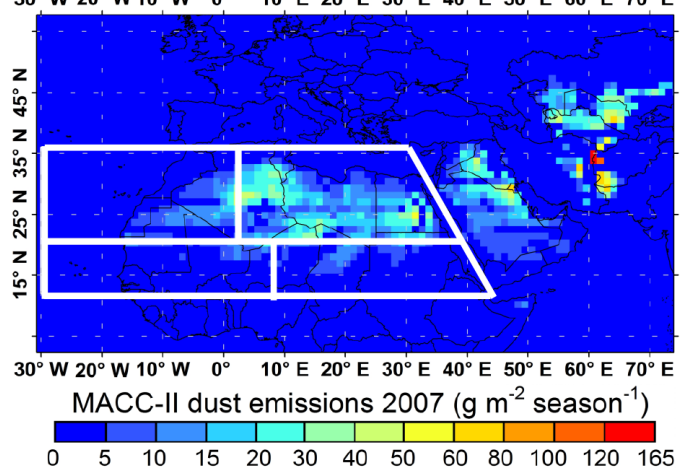

b) Spring

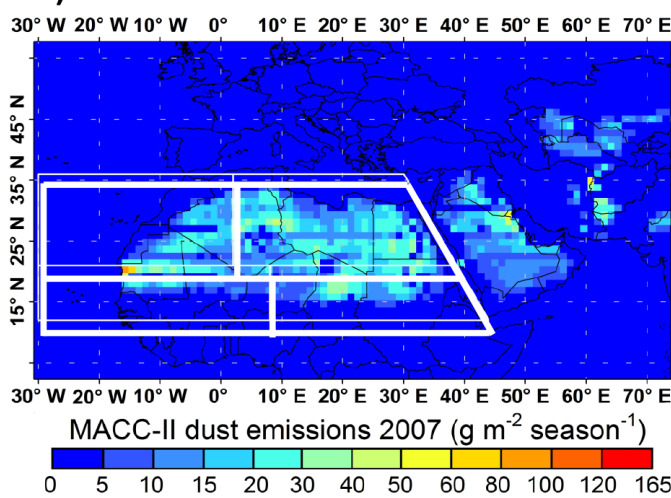

d)

Autumn

$30^{\circ} W 20^{\circ} W 10^{\circ} W \quad 0^{\circ} \quad 10^{\circ} \mathrm{E} 20^{\circ}$ E $30^{\circ}$ E $40^{\circ}$ E $50^{\circ}$ E $60^{\circ}$ E $70^{\circ} \mathrm{E}$

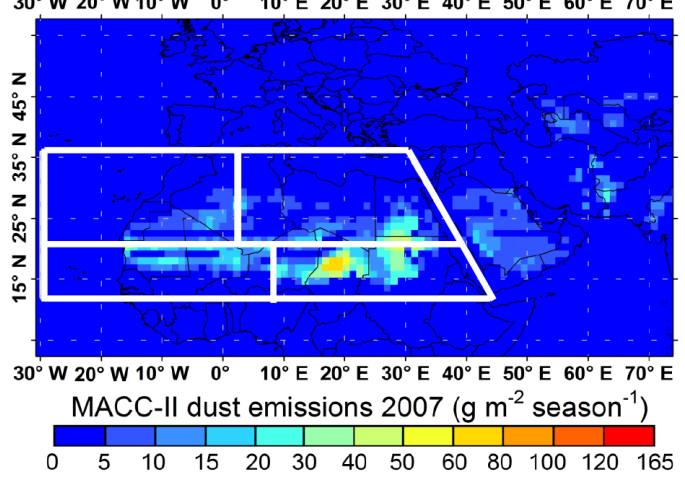

Figure 1. Accumulated daily dust emissions from MACC-II for winter (JFM), spring (AMJ), summer (JAS) and autumn (OND) 2007 $\left(\mathrm{g} \mathrm{m}^{-2}\right.$ season $\left.^{-1}\right)$. The contours of the four Sahara-Sahel sub-regions regions are marked with white lines.

fair to say that possibly the biggest impact is that of the dust parameterization and to some extent the changes in the cloud scheme.

The MACC-II reanalysis runs at T255L60, which is approximately $78 \mathrm{~km} \times 78 \mathrm{~km}$ at 60 levels. Dust is treated as a chemically non-reactive component, which is externally mixed like all other aerosols in the MACC-II model. The aerosol complex refractive index used in this reanalysis is $1.4-1.64 \times 10^{-3} i$, which has been interpolated from Dubovik et al. (2002) for desert dust.

In this study we have used MACC-II AOD and dust aerosol optical depth (DOD) at 550 nm at 06, 09, 12, 15 and 18 UTC in the period 2007-2008 to coincide with the measurement period of AERONET and satellites, which provide data only during daylight hours.

AOD at 440 and $670 \mathrm{~nm}$ from MACC-II was used to derive the Ångström exponent (AE). The total mixing ratio is converted to mass concentration $\left(\mu \mathrm{g} \mathrm{m}^{-3}\right)$ by multiplying by the air density. MACC-II yields AOD for the layers bounded by the 60 hybrid pressure-sigma levels and the surface. The extinction at each layer is calculated from the optical depth through division by the layer depth. In this work, we have used total extinction profiles and natural aerosol (dust + sea- salt) profiles. The dust surface concentration from MACC-II is calculated through the addition of the mixing ratios for the different dust size bins at the lowest model layer (approximately $2.4 \mathrm{hPa}$ thick).

\section{Observations used for the MACC-II re-analysis evaluation}

Observations of different types of aerosols and mineral dust, available in the study area, are used in this work. It should be noted that the most important ground-based observations are those performed in the vicinity of dust source regions such as the Sahara or the Middle East, which are very sparse. Therefore, aerosols measurements from satellites have been also analyzed in this study. A summary of the most important features of the observations used to validate estimated aerosols and mineral dust from MACC-II are described below. 


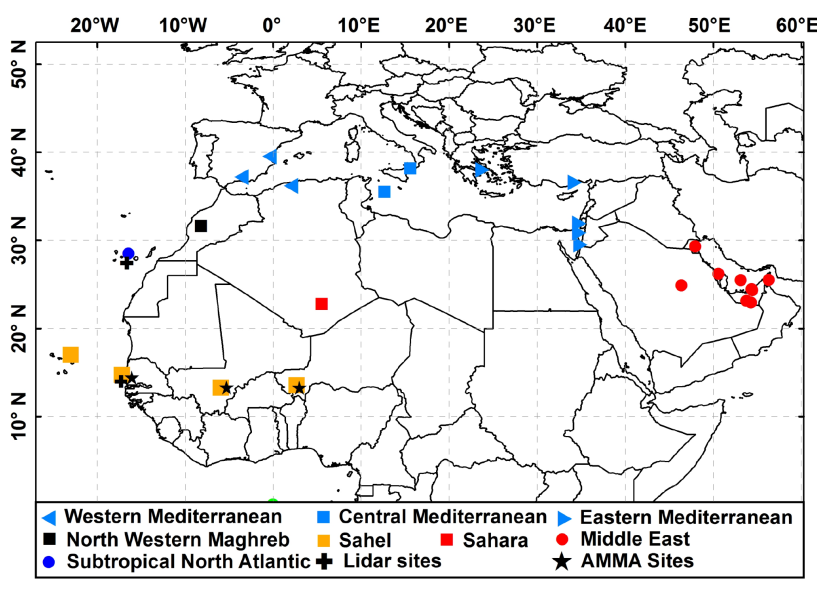

Figure 2. Localization of the AERONET stations, grouped by regions, lidar sites and $\mathrm{PM}_{10}$ monitoring stations. AERONET regions correspond to: (1) Western Mediterranean, (2) Central Mediterranean, (3) Eastern Mediterranean, (4) Middle East (5) Sahara, (6) Sahel and (7) subtropical North Atlantic.

\subsection{Ground-based observations}

\subsubsection{AERONET}

AOD and AE are obtained from the AErosol RObotic NETwork (AERONET, http://aeronet.gsfc.nasa.gov). AERONET is based on ground-based CIMEL Electronique 318A spectral sunphotometers which take direct-sun measurements automatically every $\sim 15 \mathrm{~min}$ at bands nominally centred at $\sim 340,380,440,500,675,870$, and $1020 \mathrm{~nm}$ with a $1.2^{\circ}$ field of view during daylight hours (Holben et al., 1998). AOD is determined from the direct irradiance transmission once cloud screening has been applied (Smirnov et al., 2000) using the Lambert-Beer law. The operational CIMEL sunphotometers are intercalibrated every year with reference CIMEL masters which, in turn, are absolutely calibrated using the Langley method at Mauna Loa or Izaña high mountain observatories. The accuracy in AOD determination from a newly calibrated AERONET CIMEL instrument under cloud-free conditions is $<0.01$ for wavelengths $>0.44 \mu \mathrm{m}$, and $<0.02$ for shorter wavelengths (Holben et al., 1998; Eck et al., 1999).

Stations were selected based on their location and data availability for the study period (from January 2007 to December 2008). A total of 26 AERONET stations were analyzed and grouped into eight regions with geographically distinct characteristics: Sahara, Sahel, north-western Maghreb, subtropical North Atlantic, western Mediterranean, central Mediterranean, eastern Mediterranean, and the Middle East (Fig. 2 and Table 1). We are well aware that within these regions there are some sub-regions with certain distinguishing characteristics caused by the contribution of other aerosols, in addition to dust. These distinctive features will be identified throughout this work.
Cloud-screened and calibration quality-assured AERONET Level 2.0 data (Holben et al., 1998) has been extracted for each station. Since MACC-II provides AOD at $550 \mathrm{~nm}$, we used AERONET values of the AE $(440 / 870 \mathrm{~nm})$ and the AOD at $440 \mathrm{~nm}$ to derive AERONET AODs at $550 \mathrm{~nm}$, according to the Angstrom's law:

$\mathrm{AOD}_{550}=\mathrm{AOD}_{440}\left(\frac{550}{440}\right)^{-\mathrm{AE}_{440-870}}$.

Additionally, direct-sun AOD processing includes the spectral deconvolution algorithm (SDA) retrievals (O'Neill et al., 2003). The SDA algorithm yields fine (sub-micron) and coarse (super-micron) AOD at a standard wavelength of $500 \mathrm{~nm}$ (AODfine and AODcoarse, respectively). The amplitude of the errors of the derived parameters varies as the inverse of the total AOD. In addition to measurement errors, there are errors in the AOD retrieval due to the uncertainty in the assumed values of the spectral curvature in each mode (O'Neill et al., 2001) which are most critical in coarse mode dominated conditions. AERONET Level 2.0 SDA retrievals have been used for each station, except for Messina, Saada, and the stations located in the Sahel region where only Level 1.5 retrievals are available.

\subsubsection{Lidars}

The vertical distribution of the total and natural (sea salt and mineral dust) extinction coefficient from the MACC-II 20072008 reanalysis has been validated using ground-based lidar observations. Only two operational lidars have provided extinction vertical profile data under almost pure mineral dust conditions, with climatological significance, within our study area during the period from January 2007 to December 2008: (1) at M'Bour (Dakar, Senegal, $14.4^{\circ} \mathrm{N}, 17.0^{\circ} \mathrm{W}, 13 \mathrm{~m}$ a.s.l.), and (2) at Santa Cruz de Tenerife Observatory (SCO; the Canary Islands, Spain, $28.5^{\circ} \mathrm{N}, 16.2^{\circ} \mathrm{W}, 52 \mathrm{~m}$ a.s.l.). The locations of these sites are shown in Fig. 2.

The CE370-CAML lidar located at M'Bour, near Dakar (Senegal), is an eye-safe system that comprises a Nd-Yag II laser which emits laser pulses at $532 \mathrm{~nm}$, with a duration of $10 \mathrm{~ns}$ and an energy of $\sim 20 \mu \mathrm{J}$. This lidar belongs to the Laboratoire d'Optique Atmosphérique (LOA), Université Lille, and is operational at M'Bour since 2006. Detailed information about the lidar program at M'Bour can be found in Léon et al. (2009). This instrument is used to characterize desert dust, biomass burning and marine aerosols in the Sahel region. The second lidar is located at SCO. It is a micropulse lidar version 3 (MPL-3) with a diodepumped Nd:YLF laser, emitting pulses at $523 \mathrm{~nm}$ with duration of $10 \mathrm{~ns}$ and an output energy of $\leq 7 \mu \mathrm{J}$. This instrument, which is part of the NASA MPLNet (Micropulse Lidar Network; http://mplnet.gsfc.nasa.gov/; Welton et al., 2005) since November 2005, is co-managed by the Spanish Institute for Aerospace Technology (INTA) and the Izaña Atmospheric Research Center (AEMET). One of the main objectives of 
Table 1. Name and location of the AERONET stations. Cloud screened and calibration quality-assured AERONET level 2.0 data has been extracted for each station.

\begin{tabular}{lcccl}
\hline Site name AERONET & Latitude & Longitude & Altitude m a.s.l. & Region \\
\hline Burjassot & $39.51^{\circ} \mathrm{N}$ & $0.42^{\circ} \mathrm{W}$ & 30 & Western Mediterranean \\
Granada & $37.16^{\circ} \mathrm{N}$ & $3.61^{\circ} \mathrm{W}$ & 680 & Western Mediterranean \\
Blida & $36.5^{\circ} \mathrm{N}$ & $2.88^{\circ} \mathrm{W}$ & 230 & Western Mediterranean \\
Lampedusa & $35.52^{\circ} \mathrm{N}$ & $12.63^{\circ} \mathrm{E}$ & 45 & Central Mediterranean \\
Messina & $38.2^{\circ} \mathrm{N}$ & $15.57^{\circ} \mathrm{E}$ & 15 & Central Mediterranean \\
ATHENS-NOA & $37.99^{\circ} \mathrm{N}$ & $23.78^{\circ} \mathrm{E}$ & 130 & Eastern Mediterranean \\
Eilat & $29.5^{\circ} \mathrm{N}$ & $34.92^{\circ} \mathrm{E}$ & 15 & Eastern Mediterranean \\
IMS-METU-ERDEMLI & $36.57^{\circ} \mathrm{N}$ & $34.26^{\circ} \mathrm{E}$ & 3 & Eastern Mediterranean \\
Nes_Ziona & $31.92^{\circ} \mathrm{N}$ & $34.79^{\circ} \mathrm{E}$ & 40 & Eastern Mediterranean \\
SEDE BOKER & $30.86^{\circ} \mathrm{N}$ & $34.78^{\circ} \mathrm{E}$ & 480 & Eastern Mediterranean \\
Abu Al Bukhoosh & $25.5^{\circ} \mathrm{N}$ & $53.15^{\circ} \mathrm{E}$ & 24 & Middle East \\
Bahrain & $26.21^{\circ} \mathrm{N}$ & $50.61^{\circ} \mathrm{E}$ & 25 & Middle East \\
Abu Dhabi & $24.48^{\circ} \mathrm{N}$ & $54.38^{\circ} \mathrm{E}$ & 15 & Middle East \\
Dhadnah & $25.51^{\circ} \mathrm{N}$ & $56.32^{\circ} \mathrm{E}$ & 81 & Middle East \\
Hamim & $22.97^{\circ} \mathrm{N}$ & $54.3^{\circ} \mathrm{E}$ & 209 & Middle East \\
Kuwait University & $29.33^{\circ} \mathrm{N}$ & $47.97^{\circ} \mathrm{E}$ & 42 & Middle East \\
Mezairaa & $23.15^{\circ} \mathrm{N}$ & $53.78^{\circ} \mathrm{E}$ & 204 & Middle East \\
Mussafah & $24.37^{\circ} \mathrm{N}$ & $54.47^{\circ} \mathrm{E}$ & 10 & Middle East \\
Solar Village & $24.91^{\circ} \mathrm{N}$ & $46.4^{\circ} \mathrm{E}$ & 764 & Middle East \\
Santa Cruz Tenerife & $28.47^{\circ} \mathrm{N}$ & $16.25^{\circ} \mathrm{W}$ & 52 & Subtropical North Atlantic \\
Saada & $31.63^{\circ} \mathrm{N}$ & $8.16^{\circ} \mathrm{W}$ & 420 & North-western Maghreb \\
Tamanrasset INM & $22.79^{\circ} \mathrm{N}$ & $5.53^{\circ} \mathrm{E}$ & 1377 & Sahara \\
Banizoumbou & $13.54^{\circ} \mathrm{N}$ & $2.66^{\circ} \mathrm{E}$ & 250 & Sahel \\
Capo Verde & $17.00^{\circ} \mathrm{N}$ & $23.00^{\circ} \mathrm{W}$ & 60 & Sahel \\
Dakar & $14.39^{\circ} \mathrm{N}$ & $16.96^{\circ} \mathrm{W}$ & 0 & Sahel \\
IER Cinzana & $13.28^{\circ} \mathrm{N}$ & $5.93^{\circ} \mathrm{W}$ & 285 & Sahel \\
\hline
\end{tabular}

the lidar at Santa Cruz de Tenerife is providing information of the vertical structure of the Saharan air layer (SAL) over the North Atlantic.

In both lidar stations, the raw data profiles have been range corrected (Campbell et al., 2002), and the overlap correction function has been applied using the slope method (Kunz and de Leeuw, 1993). The lidar signal in both stations can be used, for heights greater than $\sim 250 \mathrm{~m}$, due to the afterpulse. The attenuated backscatter vertical profiles were converted to vertical extinction profiles using the Klett's inversion algorithm (Klett, 1981, 1985) and the AOD values measured by co-located AERONET CIMEL sunphotometers. We used the average of the available lidar extinction profiles within a 3-h window centred at each MACC-II output hour (06, 09, 12,15 and 18 UTC) in order to perform the MACC-II extinction profiles validation.

\subsubsection{AMMA Sahelian Dust Transect}

Particulates with an aerodynamic diameter less than $10 \mu \mathrm{m}$ are referred to as $\mathrm{PM}_{10}$. The only reliable information available of in situ $\mathrm{PM}_{10}$ in regions close to dust sources is that provided by the three $\mathrm{PM}_{10}$ monitoring stations of the Sahelian Dust Transect, deployed in the frame of the African Monsoon Multidisciplinary Analysis Project (AMMA, Mar- ticorena et al., 2010). $\mathrm{PM}_{10}$ at the three AMMA stations was measured with a tapered element oscillating microbalance monitor (TEOM 1400 from Thermo Scientific) with an acquisition time of $5 \mathrm{~min}$. We have used $\mathrm{PM}_{10}$ daily means measured at three AMMA monitoring stations (see Fig. 2) from January 2007 to December 2008: (1) M'Bour in Senegal $\left(14.4^{\circ} \mathrm{N}, 17.0^{\circ} \mathrm{W}, 13 \mathrm{ma} . s .1.\right)$, (2) Cinzana in Mali (13.3 ${ }^{\circ} \mathrm{N}, 5.9^{\circ} \mathrm{W}, 282 \mathrm{ma.s.1}$ ), and (3) Banizoumbou in Niger $\left(13.5^{\circ} \mathrm{N}, 2.7^{\circ} \mathrm{E}, 191 \mathrm{ma}\right.$ a.s.1.). The location of the three stations is indicated in Fig. 2.

Although there are other $\mathrm{PM}_{10}$ stations in northern Africa and the Middle East, they are part of urban air quality networks, so the observations are strongly contaminated by anthropogenic aerosols (Liousse et al., 2010). No other rural background $\mathrm{PM}_{10}$ stations are in operation in northern Africa and the Middle East within our study period. Concerning the European Monitoring and Evaluation Programme (EMEP) and other rural background stations located in the Mediterranean basin and southern Europe, they are greatly influenced by marine aerosols and anthropogenic pollution, and only slightly affected by African dust intrusions, and therefore they are not optimal for dust models evaluation.

We have used the $\mathrm{PM}_{10}$ daily means available in the AMMA database. This data set was filtered by wind direction 
in order to select geographical sectors mainly affected by desert mineral dust during sampling, rejecting the contribution of biomass burning aerosols, and sea-salt aerosols in M'Bour. A detailed description of the $\mathrm{PM}_{10}$ AMMA stations, the measurement program, data screening and filtering, and the main spatiotemporal dust distribution is provided by Marticorena et al. (2010).

\subsection{Satellite aerosols observations}

The AOD spatial distributions obtained from satellites provide unique information to assess the spatiotemporal distributions of AOD simulated by MACC-II. This is a particularly interesting point because models do not simulate aerosols with the same skill in different regions of the Earth, and satellite sensors do not show the same accuracy to measure aerosols in all regions because data inversion is affected by meteorological conditions, land surface properties, and the magnitude of the dust loading (Banks et al., 2013). We have also used the observed AOD data from satellites over AERONET stations for comparison with AOD from MACCII, and with AERONET observations which are the reference, so we can properly assess the differences observed in the simulations.

AOD from satellite sensors and from the MACC-II reanalysis have been plotted in lat/lon maps. Satellite retrieved AODs for the pixels in which the ground stations are located are used.

\subsubsection{MISR}

The Multi-angle Imaging SpectroRadiometer (MISR) instrument, flying aboard the NASA Earth Observing System's Terra satellite (http://www-misr.jpl.nasa.gov/), gets a global coverage every 9 days with revisit time between 2 and 9 days depending on latitude. MISR scans the Earth since January 2000 using four spectral bands centred at 446, 558, 672, $867 \mathrm{~nm}$, and has nine push-broom cameras viewing at nine different angles, $0, \pm 26.1, \pm 45.6, \pm 60.0$, and $\pm 70.5^{\circ}$, covering the nadir, forward, and aft directions along the line-offlight (Diner et al., 1998).

MISR can retrieve aerosol properties (aerosol shape, size and single scattering albedo) over bright desert areas due to its unique capability of multi-wavelength observations at forward and backward directions (Kahn et al., 2005, 2010). Further details about the aerosol algorithm and its retrieval can be found in Diner et al. (2001, 2008). According to Kahn et al. (2010), $\sim 70-75 \%$ of MISR AOD retrievals fall within 0.05 or $20 \% \times$ AOD of the paired validation data from AERONET, and $\sim 50-55 \%$ are within 0.03 or $10 \% \times$ AERONET AOD, although errors might be higher at sites where dust or mixed dust and smoke are commonly found.
In this work, daily Level-3 AOD data (MILDAE3)for the green channel $(555 \mathrm{~nm})$ at $0.5^{\circ} \times 0.5^{\circ}$ spatial resolution were used for the period January 2007 to December 2008.

\subsubsection{OMI}

The Ozone Monitoring Instrument (OMI) was launched in July 2004 on NASA's EOS-Aura satellite. OMI provides aerosol information on a global scale at a daily basis, passing over a certain location once or twice a day. A detailed description of the characteristics of the OMI instrument is given by Levelt et al. (2006). Two aerosol inversion schemes are available for OMI measurements: the OMI near-UV (OMAERUV) and the multi-wavelength algorithm (OMAERO). The OMAERUV algorithm uses the range of near UV region $(354-388 \mathrm{~nm})$ to derive aerosol extinction optical depth, while the OMAERO algorithm uses up to 19 channels (330 to $500 \mathrm{~nm}$ ) in the UV and visible regions. Aerosol algorithms are described by Stammes and Noordhoek (2002) and Torres et al. (2005, 2007).

We used OMAERUV algorithm for retrieving aerosols over arid and semi-arid regions because the reflectance is small in the near-UV spectrum, whereas in the visible and near-IR these surfaces appear very bright and it is difficult to retrieve aerosols (Torres et al., 2007). However, aerosol content from OMI shows a dependence on the level height of the detected aerosol layer, and hence, dust plumes well mixed over the entire boundary layer or residual dust layers aloft may be overestimated (Ginoux and Torres, 2003).

The AURA/OMI Level 3 daily global $1^{\circ} \times 1^{\circ}$ gridded near-UV Aerosol data product (OMAERUVd) is available from Giovanni web tool (http://giovanni.gsfc.nasa.gov). The aerosol extinction optical depth (EAOD) at $550 \mathrm{~nm}$ from OMAERUVd has been used in this study.

\subsubsection{MODIS}

Moderate Resolution Imaging Spectrometer (MODIS) onboard the NASA EOS (Earth Observing System) Terra and Aqua satellites (Salomonson et al., 1989) provides aerosol properties over both land (Kaufman et al., 1997) and ocean (Tanré et al., 1997) with a near-daily global coverage.

The standard AOD product is retrieved using the darktarget approach (Kaufman et al., 1997) at near-infrared wavelengths $(2.1$ and $3.8 \mu \mathrm{m})$. Hence, this approach provides information about the global distribution of aerosols, but not over bright surfaces. The reported AOD uncertainty over non bright targets is $0.05 \pm 0.15$ AOD (Remer et al., 2005). The Deep Blue (DB) algorithm is preferable to retrieve aerosol properties over deserts (bright surfaces) because it employs two blue channels $(0.412$ and $0.470 \mu \mathrm{m})$, for which surface reflectances are relatively small (Hsu et al., 2004), in addition to that of $0.650 \mathrm{~nm}$. The uncertainties of AOD obtained with DB algorithm are 25-30\% (Hsu et al., 2006). A complete 
description of DB aerosol products retrieval biases and uncertainties is provided by Shi et al. (2013).

The daily Level 3 aerosol products from Aqua (collection 5.1, MYD08) at $1^{\circ} \times 1^{\circ}$ horizontal resolution are used in the present analysis. In fact, over the ocean and dark areas with sufficient vegetation we use the standard AOD product (MODIS dark-target product), while over desert areas (Sahara and the Middle East) we use AOD DB. In the intermediate zones where we have both products, in order to achieve a smoother transition, we use an averaged AOD of both the standard AOD and AOD DB. Therefore it should be noted that when using the MODIS dark-target product at $550 \mathrm{~nm}$, normally over the ocean, the evaluation of the reanalysis is not done with independent observations as those observations were assimilated by MACC-II. On the contrary, MODIS DB product, used over desert areas, provides an independent verification.

\subsubsection{CALIOP}

Cloud-Aerosol Lidar with Orthogonal Polarization (CALIOP) is the primary instrument on Cloud-Aerosol Lidar and Infrared Pathfinder Satellite Observations (CALIPSO) satellite launched on April 2006 by NASA. The CALIOP instrument, the first lidar with polarization capabilities in the space, utilizes three receiver channels, one measuring the $1064 \mathrm{~nm}$ backscatter intensity and two channels measuring orthogonally polarized components of the $532 \mathrm{~nm}$ backscattered signal, to provide AOD, aerosol vertical distribution and extinction (Young and Vaughan, 2009; Vaughan et al., 2009). An overview of the CALIPSO mission and CALIOP main characteristics can be found in Winker et al. (2009).

In this study we used the extinction profiles at $532 \mathrm{~nm}$ Level 2 Version III.01 with a vertical resolution of $60 \mathrm{~m}$ and with a horizontal resolution of $5 \mathrm{~km}$ over M'Bour and Tenerife. Following the method proposed by Tesche et al. (2013), we only considered high quality CALIOP profiles with Atmospheric Volume Description bits 1-3 equal to 3 (feature type $=$ aerosol), a CAD Score below -20 (screen artifacts from data Liu et al., 2010), and an extinction QC flag 532 (Young and Vaughan, 2009) of either 0 (unconstrained retrieval; initial lidar ratio unchanged during solution process) or 1 (constrained retrieval). A complete description of the CALIPSO lidar aerosol profile products can be found in the CALIPSO Data User's Guide (http://www-calipso.larc.nasa. gov/resources/calipso_users_guide/).

\section{Results}

\subsection{Aerosol optical depth}

\subsubsection{Qualitative spatial comparison with satellite observations}

An important objective of the MACC-II reanalysis evaluation is to examine its ability to reproduce aerosol spatiotemporal variability. In this section, we assess to what extent the MACC-II system is able to capture details in the spatial distribution of aerosols in our study area, and the seasonal and interannual changes. Since transport over the Atlantic Ocean is generally well observed by most satellite sensors, and well simulated by dust models, we have focused our attention on inland areas in northern Africa and the Middle East, where larger differences are expected in AOD between MACC-II and satellite observations. MISR is the most reliable of all satellite observing systems used in this study since it has been specially designed to measure with little uncertainty over high reflective surfaces, although it has difficulties to retrieve the magnitude of the largest dust events (Banks et al., 2013). For this reason, and because MODIS dark-target AOD data at $550 \mathrm{~nm}$ are assimilated by MACC-II, we have used MISR AOD as reference.

\section{Intra-annual spatial comparison}

We have computed the seasonal spatial AOD averages of MACC-II, MODIS and OMI matching the MISR observations to avoid bias due to differences in the temporal and spatial sampling, selecting those common pixels of simultaneous days, for each MISR pass, for MACC-II, MODIS and OMI. We have compared the seasonal AOD averages from MACC-II (at 12 UTC) with AOD from MISR, MODIS and OMI for the period 2007-2008 (see Fig. 3). The AOD seasonal averages of MACC-II, MISR, MODIS and OMI, using all available data for each system in the period 20072008, are shown in Fig. S1 in the Supplement. As expected, there are differences with the AOD averages computed using only common MISR data, but even so, AOD "climatologies" obtained from each satellite and from MACC-II show similarly the main AOD patterns. MACC-II AE seasonal averages (2007-2008) are shown in Fig. S2. We have computed the AOD MACC-II-MISR normalized mean bias (NMB) expressed as 100.(MACC-II-MISR)/MISR) for the four seasons (see Fig. S3). Furthermore, the accumulated daily dust emissions from MACC-II for winter (January, February and March), spring (April, May and June), summer (June, August and September) and autumn (October, November and December) $2007\left(\mathrm{~g} \mathrm{~m}^{-2}\right.$ season $\left.^{-1}\right)$, as well as the contours of four Sahara-Sahel sub-regions, are depicted in Fig. 1.

MACC-II dust emissions show seasonal patterns (see Fig. 1). In northern Africa, the Bodélé depression in Chad is the area with the highest dust emissions, achieving a 

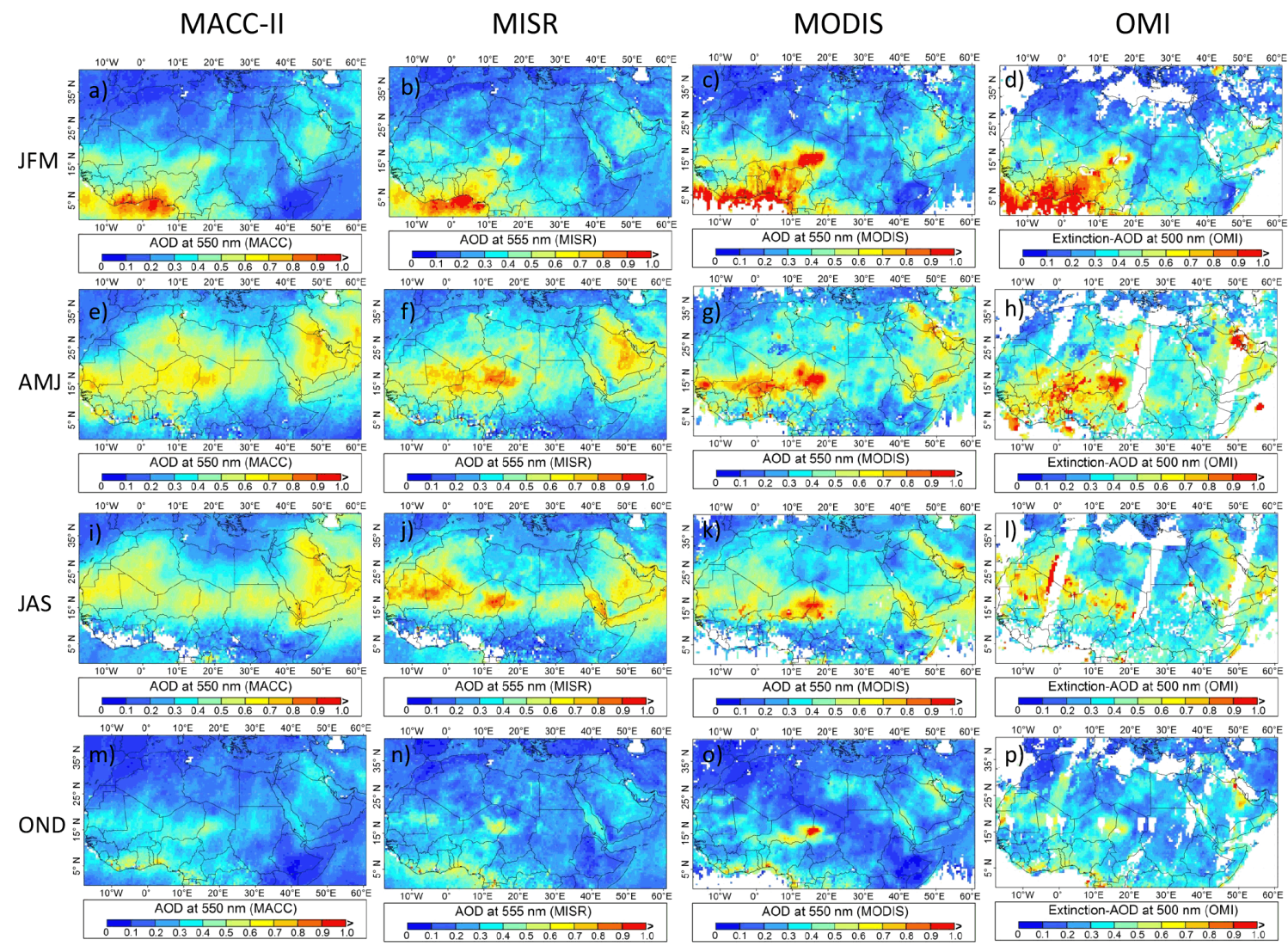

Figure 3. Seasonal AOD averages from MACC-II, MISR, MODIS and OMI for the period 2007-2008. Winter (JFM), spring (AMJ), summer (JAS) and autumn (OND). AOD averages have been computed using only those common pixels of simultaneous days, for each MISR pass, for MACC-II, MODIS and OMI.

maximum during winter and autumn months. The winter dust activity is maximum in low latitudes, and as the year progresses, dust activity shifts to higher latitudes. The emission activity is driven by the latitudinal shift of the Intertropical Front which corresponds to the convergence zone between the dry northern winds, called the Harmattan, and the humid monsoon winds from the south. During spring and summer, the dust activity is at its maximum and the dust transport shifts to northern latitudes. Over much of the Arabian Peninsula, the main dust sources extend in a continuous band from the northern part of the Tigris-Euphrates basin to the coast of Oman. Dust activity increases strongly in spring and summer, and weakens in winter and autumn.

The seasonal AOD fields from MACC-II also show a distinct seasonal pattern linked the spatial distribution of dust emissions throughout the year (Fig. 3). Winter is characterized by showing low AOD values in most regions of our geographic domain (Fig. 3a-d), except in the Gulf of Guinea. The similarity between MACC-II and MISR is noteworthy. The AOD MACC-II-MISR NMB ranges from -40 to $+40 \%$ within most of the study domain, except in Turkey, and Iran where the ratios are $>+40 \%$ (Fig. S3a). The MACC-II AE values $<0.3$ are only observed over the Sahara (Fig. S2a). In winter, MACC-II shows high dust emission values (Fig. 1a) in the Bodélé, which are linked to moderate AOD values $(<0.6$; Fig. 3). In this season, dust is transported southwestward from the Bodélé and adjacent areas at low levels by the northeastern Harmattan winds (Cavalieri et al., 2010) limiting the dust long-range transport. High values of AOD $(>0.7)$ in the Gulf of Guinea, and moderate AOD $(>0.5)$ south of parallel $20^{\circ} \mathrm{N}$ in western Africa, the Arabian Peninsula and in the Iraq-Persian Gulf corridor are observed in a similar way by MACC-II, MISR and MODIS (Fig. 3a-c). MODIS shows the same structures but with slightly higher values. Qualitatively, OMI shows higher AOD values than MODIS, MISR and MACC-II over the North Atlantic, eastern Mediterranean/northern Africa and the Arabian Peninsula. MODIS observes higher AOD values in the Sahel. According to Schepanski et al. (2012) aerosols from biomass burning over the Sahel during November to March contribute to very high AOD observed by MODIS over this region. This result is confirmed with the AE simulated fields by MACCII that show higher values $(>0.6)$ indicating the presence of fine aerosols (Fig. S2a). Only significant signals associated to coarse dust aerosols are observed in the Bodélé 
(AOD > 0.6), and very weak in the Sahel, in Iraq and in the southern part of the Red Sea.

In spring a considerable increase in dust activity in the North Sahel, the Sahara and the Arabian Peninsula, and a considerable reduction of AOD in the Gulf of Guinea is observed (Fig. 3e-h). This corresponds with significantly lower MACC-II AE values over the Sahara and the Arabian Peninsula, and higher MACC-II AE over the Gulf of Guinea (Fig. S2b). The most remarkable feature is that MACC-II underestimates over the Bodélé, and overestimates in North Sahara. Increased AOD over the Arabian Peninsula and the Iraq-Persian Gulf corridor is simulated by MACC-II with AOD values close to those observed by MISR. The MACCII-MISR NMB values fall within $\pm 40 \%$ (Fig. S3b), except in Iran and some parts of the Sahara where ratios are $>+40 \%$. However, MODIS does not record such a large increase over the Arabian Peninsula, and instead shows higher AOD values over the Iraq-Persian Gulf corridor. OMI overestimates with respect to MODIS, MISR and MACC-II, throughout the Atlantic and much of the Mediterranean, partly because the OMI AOD corresponds to shorter wavelengths. Atmospheric dynamics in combination with boundary layer mixing may also contribute to local overestimation of dust plumes in OMI (Schepanski et al., 2012).

In summer, we observe a significant reduction in AOD in northeast Africa, the eastern Mediterranean basin, and the Sahel, compared with spring, which corresponds to significantly higher MACC-II AE values (>0.9) (Fig. S3c), and an increase in Mauritania-Mali area, in the Arabian Peninsula, and the southern part of the Red Sea (Fig. 3i-1). It is remarkable that MACC-II captures well the high AOD values in the southern part of the Red Sea, clearly observed by MISR and MODIS. These high AOD values are likely produced by a channelling process caused by higher altitudes of the Red Sea at its southern half. These high altitudes act as a trap for desert dust (Israelevich, 2014). The AOD distribution from MACC-II is very similar to that of MISR, with MACC-II-MISR NMB values generally within $\pm 40 \%$, except in central Africa, Turkey, Iran, and in the same regions over the Sahara observed in spring, where the NMB values are $>60 \%$ (Fig. S3c). However, the relatively low AOD simulated by MACC-II over the Bodélé and the low values of AOD from MODIS DB over the Arabian Peninsula are noteworthy.

Finally in autumn, the lowest annual AOD values are observed by satellites and simulated by MACC-II (Fig. 3m-p). In contrast to winter, in this season high AOD values are not observed over the Gulf of Guinea, only on the coast line. The unique hot-spot which is well observed by the three satellite sensors is the Bodélé depression, with relatively high values of AOD, which is underestimated by MACC-II. In this area, however, MACC-II simulates the lowest AE values $(<0.1)$ (Fig. S2d). The AE distribution simulated by MACCII is quite similar to that of winter, although with lower values over the centre of the Arabian Peninsula. Also remark- able are the relatively high values of MACC-II AE in the Nile Delta and southern Persian Gulf. Concerning MACCII-MISR NMB, both positive and negative values are quite similar to those found in winter (Fig. S3d).

The agreement between MISR, OMI, MODIS and MACCII is, in general, very good, reproducing the same AOD patterns in the four seasons (Fig. 3). In this MACC-II evaluation, it is important to note that over desert regions such as North Africa and the Middle East, the AOD values from MISR and MODIS (fundamentally AOD DB) products have differences of around 0.1 to 0.3 (Shi et al., 2011).

Particular spatial discrepancies include the low AOD values simulated by MACC-II in the Bodélé. According to Schmechtig et al. (2011), the observed surface wind velocities in the Bodélé depression are as high as $20 \mathrm{~m} \mathrm{~s}^{-1}$ while surface wind velocities from ECMWF never exceed $12 \mathrm{~m} \mathrm{~s}^{-1}$. Since dust emission fluxes are computed as a power 3 of the wind velocity, this bias in surface winds might explain the lower AOD values provided by MACC-II over this region.

A major disagreement between MISR and MODIS is found in the Arabian Peninsula in spring (Fig. $3 \mathrm{f}$ and $\mathrm{g}$ ) and summer (Fig. 3j and k). This had been reported previously by Shi et al. (2011) who found that one of the regions of the world where the MISR retrievals are much greater than those from the MODIS is the Arabian Peninsula. From the comparison between MISR and MODIS with AERONET observation site at Solar Village (Saudi Arabia), performed by Shi et al. (2011), we can conclude that at this site there is better AERONET/MISR agreement than AERONET/MODIS agreement. Also MACC-II agrees better with MISR than with MODIS.

Large differences observed between satellite and modelled values are also linked to the coarser spatial resolution used in the MACC-II reanalysis (> $50 \mathrm{~km}$ in the horizontal, Sect. 2). This is a limitation to reproduce some mesoscale meteorological processes that favour the production of intense mineral dust outbreaks particularly in summer in northern Africa (i.e. Knippertz and Todd, 2012; Tegen et al., 2013) and in coastal regions in the Middle East (Rezazadeh et al., 2013).

\section{Interannual spatial comparison}

At present it is not possible to know with sufficient detail the causes behind the interannual variability of mineral dust (Rodríguez et al., 2014, and references herein). However, it is known that much of the year-to-year dust variability is modulated by changes in large-scale atmospheric circulation patterns as well as land surface conditions. In this section, we assess how MACC-II is able to capture the interannual variations of AOD, by comparing with interannual variations recorded by satellites. We calculated the percentage differences in AOD between 2007 and 2008 observed by MISR, MODIS and OMI, and simulated by MACC-II for each month and for the four seasons (see Fig. 4), using only 

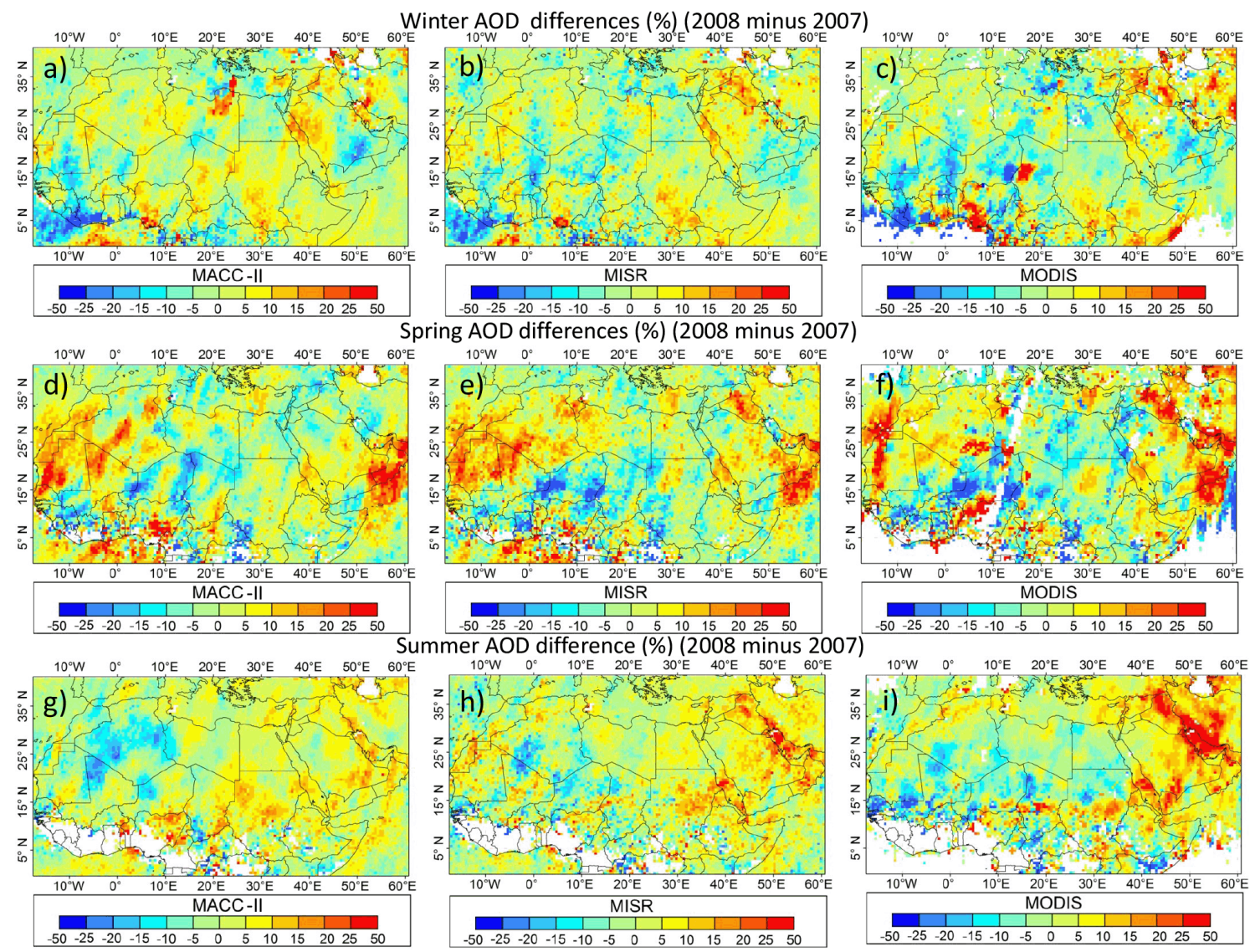

Figure 4. Interannual percentage variations of AOD (2008 minus 2007) from MACC-II, MODIS-Aqua and MISR for winter (JFM), spring (AMJ), summer (JAS).

simultaneous AOD observations/simulations with MISR. For the sake of brevity, we only show the results of the interannual differences corresponding to winter, spring and summer, since in autumn the interannual variations were very small.

In winter, MISR and MODIS show decreases in AOD (15$50 \%$ ) from 2007 to 2008 in western Africa and the Sahel, in the eastern Mediterranean, and south of the Arabian Peninsula, and AOD increases, (10 and $20 \%$ ) in eastern Syria, Iraq and the northern Persian Gulf, as well as in the northern half of the Red Sea (Fig. 4b and c). MACC-II captures quite well all these AOD interannual changes in these regions (Fig. 4a). Qualitatively, the patterns of the AOD differences observed by MISR and MODIS and simulated by MACC-II are quite similar.

In spring, MISR and MODIS observe lower values (5$20 \%$ ) in 2008 compared to 2007 (Fig. 4e and f) in much of the Sahel, in a band stretching from the Sahel to the eastern Mediterranean across south eastern Libya and Egypt, and in the central and western Mediterranean. These differences are well simulated by MACC-II (Fig. 4d). Regarding increases in AOD, these are similarly observed (5-20\%) by both MISR and MODIS over the western part of the Sahara (Algeria, Mauritania and southern Morocco). The satellites also recorded increases in the Gulf of Guinea (10-15\%), in Turkmenistan (10-20\%), especially by MODIS, the southern half of the Red Sea, and in a wide and long corridor that goes from Iraq to the Arabian Sea (15-25\%). All AOD increases are correctly simulated by MACC-II except the significant increase over Iraq, which is clearly underestimated $(0-5 \%)$ by MACC-II.

In summer, in general, the AOD interannual changes simulated by MACC-II (Fig. 4g) agree much better with the AOD changes observed by MISR (Fig. 4h) than with those detected by MODIS (Fig. 4i). The AOD decreases (10-20\%) registered by MISR and MODIS on the western centre of the Sahara (Algeria and the northern half of Niger) are well simulated by MACC-II. However, reductions in AOD observed by MODIS in the eastern Sahara are not detected by MISR nor simulated by MACC-II. MODIS shows a very strong AOD increase in 2008 compared to 2007 over the Iraq-Oman corridor with very high values $(20-50 \%)$ in Iraq and the Persian Gulf, which are also recorded by MISR. These values, despite being well simulated by MACC-II, appear to be smoothed and less intense. MODIS observes strong AOD increases (15-25\%) over southern Iran, Turkmenistan and Azerbaijan, which are not observed by MISR nor simulated 
by MAAC-II. MACC-II simulates, with smoothed values, increased AOD in the southern half of the Red Sea, recorded by MODIS and MISR, and moderate increases (10-15\%) between Chad and Sudan that are registered by both MISR and MODIS.

In summary, MACC-II is able to correctly simulate the interannual variations of AOD for the 2-year period 20072008 in each season showing a better agreement with MISR than with MODIS. The dust corridor from Iraq to Oman, covering the entire Persian Gulf, is the region of our study domain in which MACC-II and satellite sensors show the greatest AOD interannual changes, probably because in Syria and Iraq (Mesopotamian region), soil conditions are closely linked to interannual changes in water availability. It is in this region where MACC-II has greater difficulties correctly simulating the interannual changes.

\subsubsection{Quantitative comparison with ground-based and satellite observations}

In this section, we evaluate the ability of the MACC-II model to reproduce the dust cycle in our study region. MACC-II AOD is quantitatively evaluated by means of the comparison against AERONET and satellite data (MODIS and OMI) in different geographic regions using AERONET as the reference (see Fig. 2). MISR is discarded here due to its low temporal resolution (see Sect. 3.2.1) in comparison with MODIS and OMI.

For this comparison, AOD and AE outputs from MACCII at 06, 09, 12, 15 and 18 UTC have been evaluated with near AOD and AE from AERONET observations averaged for these hours $( \pm 90 \mathrm{~min})$ at the 26 AERONET stations used in this study (Table 1 and Fig. 2). Moreover, the daily AOD product provided by MODIS and OMI (see Sect. 3.2) over the selected AERONET stations is also included in the analysis.

A set of standard skill scores defined within the MACCII project (see Appendix A) have been computed using data from those days of the period 2007-2008 when there are simultaneous data of MACC, OMI, MODIS and AERONET. They have been computed on a monthly and seasonal basis for each AERONET station and for the eight sub-regions defined in Fig. 2 and Table 1. To represent the results we have used seasonal (Fig. 5) and monthly (Fig. 6) series as well as Taylor diagrams (Fig. 7), where daily AOD from MACC II, MODIS and OMI are compared each other using AERONET as the reference. We show the six most relevant regions for the sake of brevity: Sahara, Sahel, the Middle East, eastern Mediterranean, western Mediterranean and subtropical North Atlantic.

Dust content is difficult to verify because bulk optical observations are not specific for dust. Since AOD is the degree to which a mixture of atmospheric aerosols prevents the transmission of light by absorption or scattering, a criteria is needed for filtering data to ensure that most of the
AOD is influenced by mineral dust, i.e. the dust optical depth (DOD). Nevertheless, the criteria should not be as restrictive as to reduce drastically the number of observations because it would preclude proper assessments of this evaluation in dust transport regions where mineral dust concentrations are significantly lower than in near-source regions. For the present AERONET comparison, we used AE $<0.6$ as a first approach to discriminate when mineral dust is the main aerosol component in the direct-sun AERONET data set according to previous studies (Duvobik et al., 2002; Wang et al., 2004; Todd et al., 2007; Basart et al., 2009). A second approach was to consider the coarse mode of AOD as a proxy of DOD, utilising the AERONET $500 \mathrm{~nm}$ coarse mode AOD from the SDA retrievals (O'Neill et al., 2003). Skill scores obtained for 2007 and 2008 (Table 2) indicate the level of agreement between MACC-II and AERONET DOD, using both above approaches.

By using the criterion of AODcoarse from the SDA retrieval, while the number of paired data points in the MACCII-AERONET evaluation experienced no significant changes in the Sahara and the Sahel, this number grew significantly in other regions, especially in the dust transport corridors such as the Mediterranean regions, the North-western Maghreb and the subtropical North Atlantic. In long-range transport areas (i.e. North Atlantic and the Mediterranean), the AE filter applied to direct-sun AOD observations $(\mathrm{AE}<0.6)$ just takes into account pure desert dust situations. Desert dust events in these regions are sporadic and consequently the number of observations is very low.

The modified normalized mean bias (MNMB) for AODcoarse from SDA retrieval showed varying results, improving in some regions and worsening in others in comparison with direct-sun DOD observations. The mean bias (MB) improves in all regions in comparison with the direct-sun DOD AERONET observations, except in the Sahara. In this sense, it is worthy to mention that AODcoarse considers super-micron aerosols. Meanwhile, the model takes into account all their bins, including sub-micron particles. Concerning the correlation coefficient, it increases significantly in all regions, except in the Sahel and central Mediterranean. We confirmed that the approach to estimate DOD using AOD coarse from the SDA retrievals is quite reasonable because the seasonal averaged MACC-II AE is $<0.6$ in all dust source regions (except in winter, when $\mathrm{AE}<0.7$, see Fig. 5d). Considering the previous results, the AODcoarse from the SDA retrieval is used for the discussion of the results hereinafter. The MACC-II evaluation against AODcoarse from the SDA retrieval (i.e. DOD) is performed in a rather large range of DOD values, averaged by seasons and geographic regions, with DOD $<0.1$ in dust transport regions, such as the Mediterranean basin and the subtropical North Atlantic, and DOD $>0.35$ in source regions (Sahara and the Middle East) (Fig. 5a and b). Overall DOD seasonal variation is well captured by MACC-II in all regions, with correlations higher in dust transport regions than 

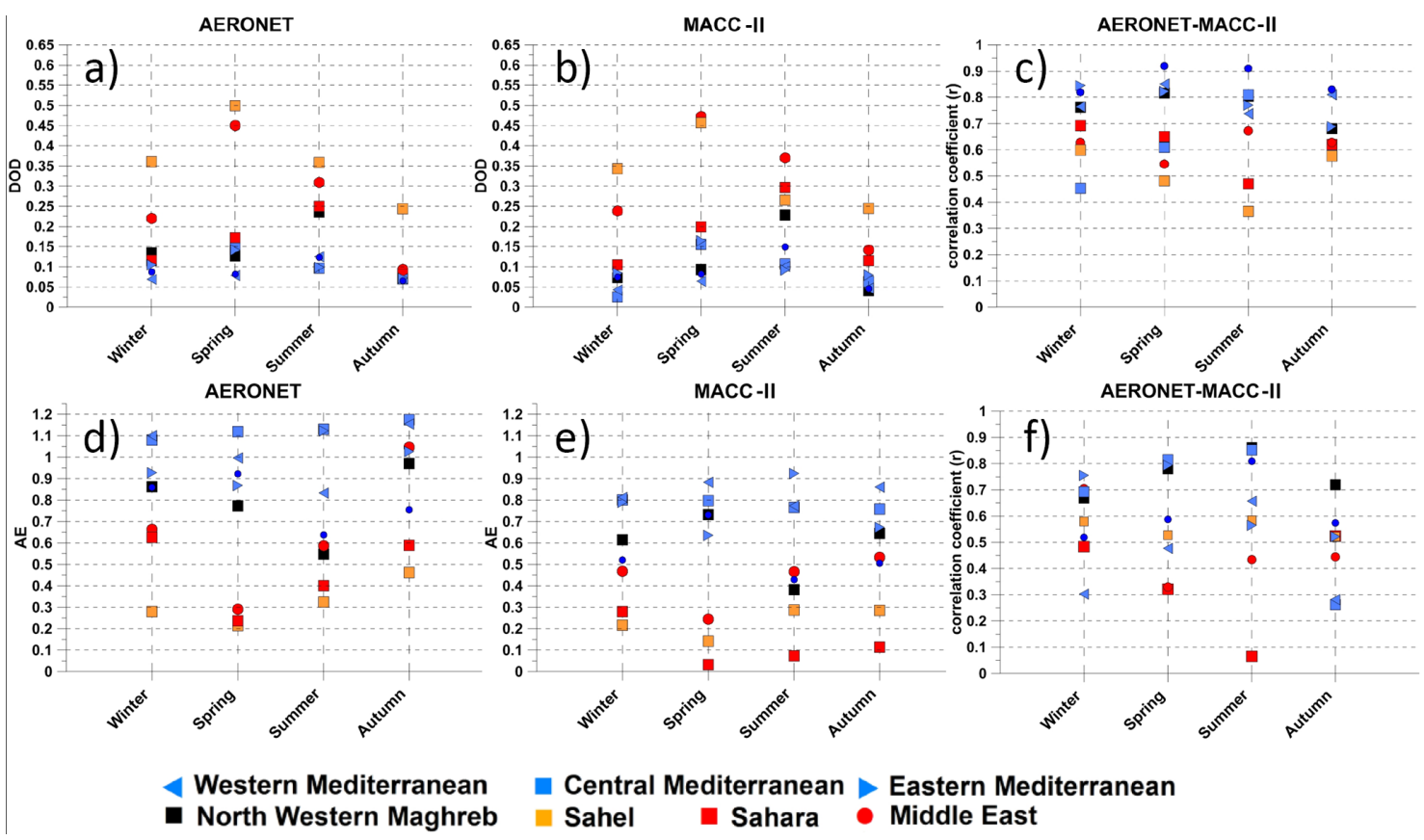

Western Mediterranean
North Western Maghreb

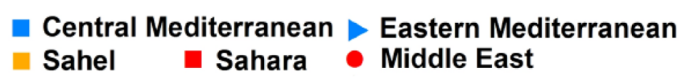

Figure 5. Seasonal averages of AODcoarse (DOD) from AERONET (a) and MACC-II (b) for each region. Seasonal averages of the DOD correlation coefficient (c) for each region. Seasonal averages of AE from AERONET (d) and MACC-II (e) for each region. Seasonal averages of the AE correlation coefficient (f). This statistics corresponds to the period 2007-2008.

in dust source regions (Fig. 5c), except in winter for the Central Mediterranean. In summer, when the maximum dust activity is observed over the Sahara, we observe the highest correlation $(r>0.70)$ in all dust transport regions, and the poorest correlation in the Sahara and the Sahel $(r<0.50)$. In general, the seasonal variation of $\mathrm{AE}$ is well captured by MACC-II in all regions, but a significant underestimation is observed (Fig. 5d and e), with differences ranging from 0.1 to 0.5 depending on regions and seasons. The correlation in $\mathrm{AE}$ is clearly lower than that found for AOD (Fig. 5f and Table 2). This can be attributed to missing fine aerosol sources and secondary processes that are not included in MACC-II.

On an annual basis, the root mean square error (RMSE) varies between 0.27 in the Sahel to 0.06 in the subtropical North Atlantic (Table 2). In the Sahara and the Middle East, MACC-II overestimates the observations, with a mean bias (MB) of 0.11 and 0.04 , respectively. The lowest correlations are found in the Sahara and Sahel (0.54). In the rest of the regions a moderate to good correlation $(r>0.70)$ is found, being relatively high in dust transport regions $(r>0.80$, except for Central Mediterranean).

In the next sections, a detailed analysis by regions is presented. For the sake of brevity we only show the individual results of the MACC-II-AERONET comparison in six stations considered representative of the most characteristic regions we identified in our study domain (Fig. 6). MACCII and AERONET daily DOD means records for the period 2007-2008, at these six stations, are available in Fig. S4.

\section{Sahara}

Tamanrasset is a station in the centre of the Sahara desert (southern Algeria). A detailed characterization of the AERONET Tamanrasset station can be found in Guirado et al. (2014). Both AOD and DOD annual variation is well captured by MACC-II (Fig. 6a and b) but some overestimation is found in June, July and October in comparison with AERONET observations. The comparison of DOD daily values from MACC-II and AERONET demonstrates the summer overestimation in more detail (Fig. S4a). However, the daily comparison also highlights some very high DOD values recorded by AERONET that are not well captured by MACC-II. These events are normally observed in summer associated with mesoscale convective processes (Tegen et al., 2013) south of Tamanrasset and driven by the monsoon. Despite these features, the summer MACC-II-AERONET correlation coefficient $(r \sim 0.45)$ is significantly higher than the correlation coefficient between the COSMO regional model and AERONET (0.14) reported by Tegen et al. (2013).

The best correlation (0.93) and the lowest fractional gross error (FGE) in DOD (0.64) is found in April, while the lowest correlation (0.05) and the highest FGE (1.03) correspond to January because in this month the AERONET DOD is extremely low (0.03).

A significant finding is the large underestimation of MACC-II AE, observed all year, but especially from June to January (Fig. 6c). This clear bias might be partially explained by the re-balanced dust emissions scheme used in 

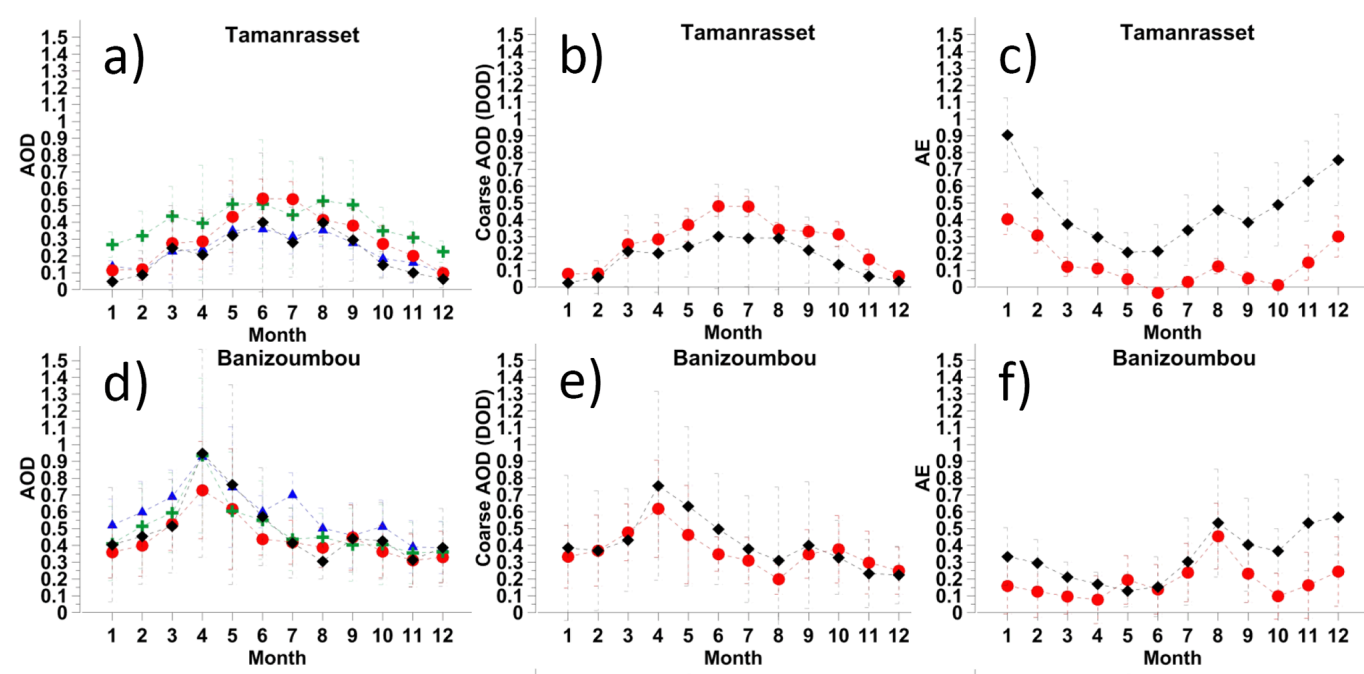

e)
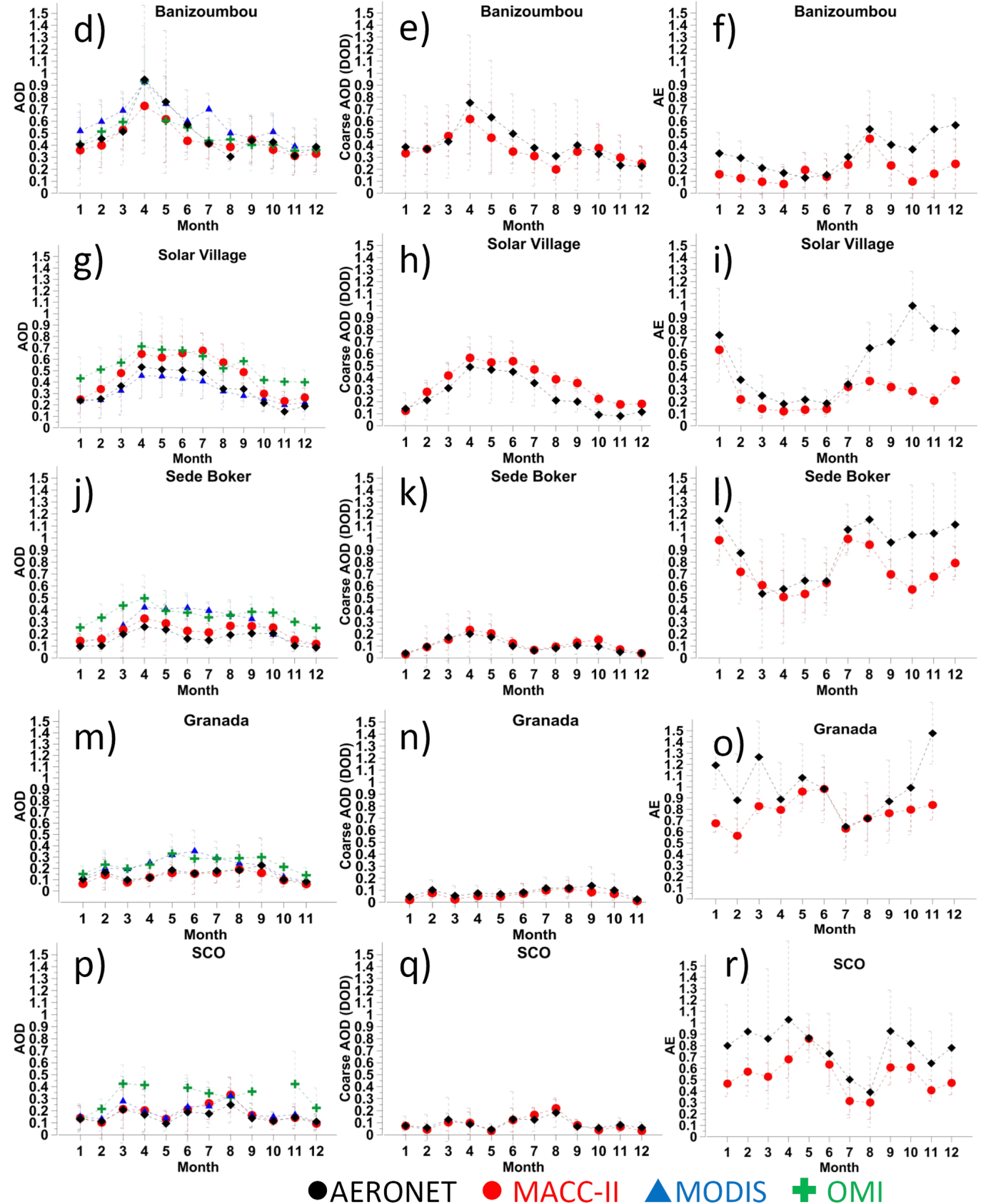

Figure 6. Monthly averages (2007-2008) of AOD from AERONET, MACC-II, MODIS-Aqua and OMI, AODcoarse (DOD) from AERONET and MACC-II, and AE from AERONET and MACC-II over Tamanrasset (a, b and $\mathbf{c})$, Banizoumbou $(\mathbf{d}, \mathbf{e}$, and $\mathbf{f})$, Solar Village $(\mathbf{g}, \mathbf{h}$ and $\mathbf{i})$, Sede Broker (j, k and $\mathbf{l})$, Granada (m, $\mathbf{n}$ and $\mathbf{o})$ and Santa Cruz de Tenerife (SCO) (p, $\mathbf{q}$ and $\mathbf{r})$. 

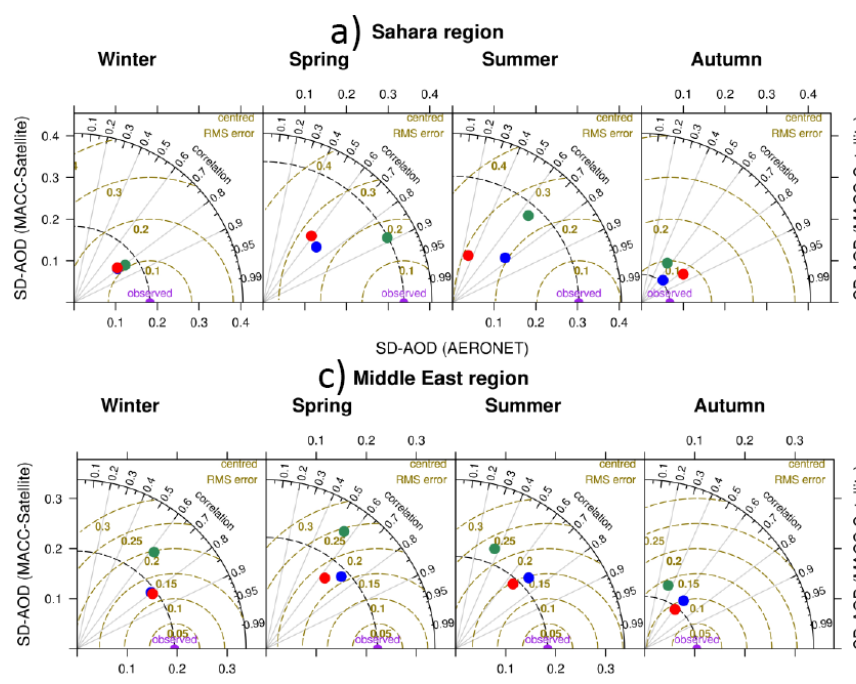

SD-AOD (AERONET)

e) Western Mediterranean region

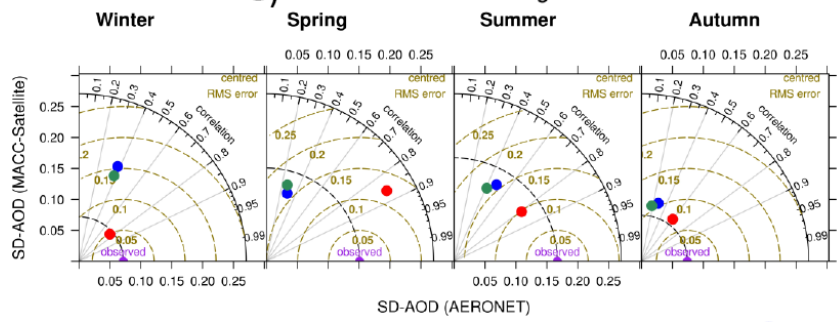

MODISAOD

OMI Extinction AOD

MACC-II AOD

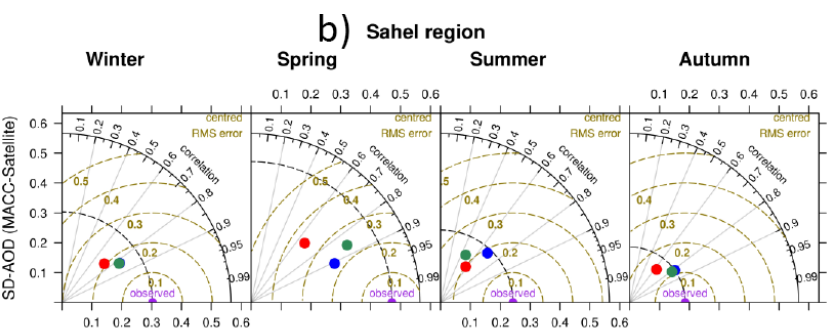

SD-AOD (AERONET)

d) Eastern Mediterranean region

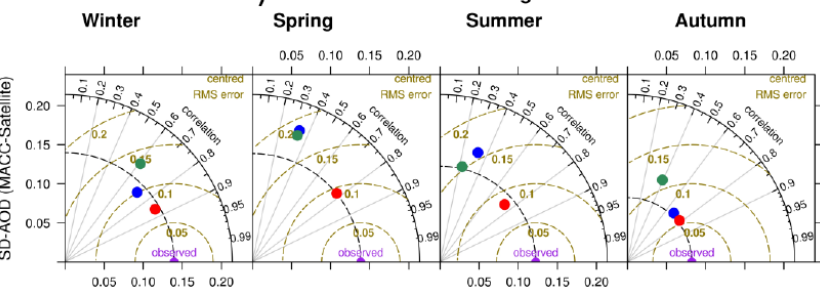

SD-AOD (AERONET)

f) Subtropical North Atlantic region

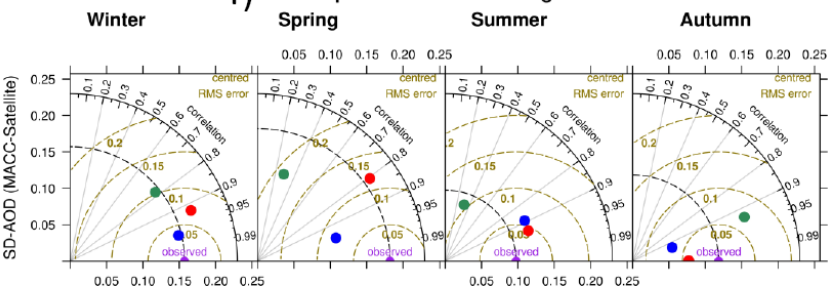

SD-AOD (AERONET)

Figure 7. Taylor diagrams where seasonal AOD values from MACC-II, MODIS-Aqua and OMI are compared with AERONET AOD, used as reference, for Sahara (a), Sahel (b), Middle East (c), Eastern Mediterranean (d), Western Mediterranean (e), and subtropical North Atlantic (f). The similarity between MACC-II and satellite observations with AERONET observations is quantified in terms of their correlation, their centred root-mean-square error (CRMSE), and the amplitude of their variations (represented by their SDs).

this MACC-II reanalysis which produces coarser dust particles by introducing dust mass in relation $0.5,2,4$ into the fine, medium and coarse dust bins, respectively. Moreover, missing local anthropogenic sources in North Africa (e.g. Liousse et al., 2010; Rodriguez et al., 2011) not considered in the model can affect these lower MACC-II AE values. High $\mathrm{AE}$ values found in December and January $(>0.7)$ are associated with very low DOD $(<0.05)$ which correspond to pristine conditions in winter (Guirado et al., 2014). Under very clear conditions, the scatter in AOD values is larger and the Ångström formula does not fit well (Pedrós et al., 2003; Kaskaoutis et al., 2006, 2007) resulting in higher uncertainties in AE determination.

Compared with satellites, we observe a good agreement between MACC-II and MODIS (Fig. 7a), except in summer, although the agreement between MACC-II and AERONET is worse than the agreement MODIS-AERONET. MACC-II behaves better than OMI, which significantly overestimates AOD throughout the year (Fig. 7a).

\section{Sahel}

In the Sahel we focus on the results at the Banizoumbou station (Niger), the station located in the innermost part of the "Sahelian Dust Transect" (Marticorena et al., 2011). The agreement in monthly AOD averages between MACC-II and AERONET is better than the agreement between MODIS and AERONET, for most of the months, and similar to that of OMI (Fig. 6d). In this station, we had the opportunity to compare with other model validation analysis. The daily AOD correlation between MACC-II and AERONET for the period 2007-2008 at Banizoumbou is 0.62, while the correlation between the regional CHIMERE model and AERONET at this station reported by Schmechtig et al. (2011) for 2006 is 0.44 .

The DOD month-to-month variability is satisfactorily tracked by MACC-II (Fig. 6e). The best correlation is found in January and February (0.77 and 0.81 , respectively), with a relatively low FGE ( 0.52 and 0.40 , respectively). During these months strong Harmattan winds transport dust from the Sahara. The maximum DOD is observed in April, just before the wet season driven by the monsoon. During the 
Table 2. Skill scores quantifying the level of agreement between MACC-II and AERONET AE and DOD (obtained from direct-sun and AODcoarse from the SDA retrievals) daily means, obtained by regions.

\begin{tabular}{|c|c|c|c|c|c|c|c|}
\hline \multicolumn{8}{|c|}{ MACC-II AE vs. AERONET AE } \\
\hline Region & & MB & MNMB & FGE & RMSE & $r$ & $n$ \\
\hline Western Mediterranean & 1 & -0.17 & -0.16 & 0.39 & 0.40 & 0.47 & 1175 \\
\hline Central Mediterranean & 2 & -0.32 & -0.36 & 0.45 & 0.45 & 0.76 & 244 \\
\hline Eastern Mediterranean & 3 & -0.23 & -0.27 & 0.43 & 0.39 & 0.68 & 1571 \\
\hline Subtropical North Atlantic & 4 & -0.25 & -0.39 & 0.50 & 0.44 & 0.62 & 485 \\
\hline North-western Maghreb & 5 & -0.18 & -0.37 & 0.48 & 0.32 & 0.75 & 561 \\
\hline Sahel & 6 & -0.08 & -0.32 & 0.65 & 0.22 & 0.55 & 2191 \\
\hline Sahara & 7 & -0.34 & -1.00 & 1.09 & 0.44 & 0.44 & 339 \\
\hline Middle East & 8 & -0.21 & -0.33 & 0.62 & 0.40 & 0.63 & 1855 \\
\hline \multicolumn{8}{|c|}{ MACC-II DOD vs. AERONET DOD (AOD with AE $\leq 0.6$ ) } \\
\hline Region & MB & MNMB & FGE & RMSE & $r$ & $n$ & \\
\hline Western Mediterranean & -0.10 & -0.54 & 0.63 & 0.20 & 0.65 & 234 & \\
\hline Central Mediterranean & -0.07 & -0.39 & 0.57 & 0.19 & 0.64 & 55 & \\
\hline Eastern Mediterranean & -0.09 & -0.41 & 0.54 & 0.19 & 0.77 & 336 & \\
\hline Subtropical North Atlantic & -0.06 & -0.57 & 0.65 & 0.13 & 0.80 & 196 & \\
\hline North-western Maghreb & -0.11 & -0.49 & 0.54 & 0.17 & 0.75 & 209 & \\
\hline Sahel & -0.14 & -0.33 & 0.44 & 0.30 & 0.67 & 2204 & \\
\hline Sahara & 0.02 & 0.20 & 0.49 & 0.26 & 0.47 & 331 & \\
\hline Middle East & -0.09 & -0.15 & 0.34 & 0.27 & 0.56 & 1036 & \\
\hline \multicolumn{8}{|c|}{ MACC-II DOD vs. AERONET DOD (AOD coarse using Spectral Deconvolution Algorithm) } \\
\hline Region & $\mathrm{MB}$ & MNMB & FGE & RMSE & $r$ & $n$ & \\
\hline Western Mediterranean & -0.02 & -0.64 & 0.79 & 0.09 & 0.80 & 855 & \\
\hline Central Mediterranean & -0.02 & -0.45 & 0.77 & 0.16 & 0.60 & 295 & \\
\hline Eastern Mediterranean & 0.00 & -0.16 & 0.55 & 0.07 & 0.81 & 1587 & \\
\hline Subtropical North Atlantic & 0.00 & -0.28 & 0.73 & 0.06 & 0.87 & 487 & \\
\hline North-western Maghreb & -0.03 & -0.68 & 0.79 & 0.10 & 0.80 & 604 & \\
\hline Sahel & -0.04 & -0.01 & 0.42 & 0.27 & 0.54 & 2064 & \\
\hline Sahara & 0.11 & 0.68 & 0.79 & 0.22 & 0.54 & 468 & \\
\hline Middle East & 0.04 & 0.24 & 0.42 & 0.18 & 0.71 & 1902 & \\
\hline
\end{tabular}

rainy season a slight underestimation of MACC-II DOD is observed, likely related with dust emitted by wet mesoscale convective events (Marticorena et al., 2010) associated with the monsoon, which are not well reproduced by MACC-II (see Fig. S4b). The lowest correlation is recorded in August (0.20) and September (0.26), months in which we found slightly higher FGE ( 0.58 and 0.45 , respectively). These results agree with the fact that MACC-II dust emissions are negligible across the Sahel (Fig. 1c) in summer. The yearly course of AE is well captured by MACC-II (Fig. 6f). However a clear underestimation is observed from September to February. This might be a fingerprint of the re-balanced dust emissions scheme in MACC-II with too many coarse particles in source regions. This is a period driven by the Harmattan winds carrying dust from the Sahara in a relatively short path in which there is hardly time for coarse particles deposition. When the Sahelian stations are grouped, we find a moderate correlation between MACC-II and AERONET daily DOD values (0.55), the same as for the Sahara (Tamanrasset), but with a number of data 4 times higher (Table 2). MACC-II, MODIS and OMI behave quite similarly (Fig. 7b), although MACC-II deviates slightly from MODIS and OMI in spring, showing poorer scores.

\section{Middle East}

In the Middle East, Solar Village (Saudi Arabia), located in the centre of the Arabian Peninsula, is a long-term high quality AERONET station. The AOD annual course from MACC-II is in good agreement with AERONET and MODIS (Fig. 6g), but a clear overestimation is observed from April to September, period when the maximum monthly AOD is observed with a peak in April-May. OMI overestimates AOD more than MACC, and it does throughout the whole year. MACC-II AOD overestimation is significantly reduced in case of DOD and is restricted to the period July-October 
(Fig. 6h). Solar Village shows a rather broad range of correlation coefficients, with minimum in December (0.38) and maximum in October (0.82). The FGE ranges from 0.36 in April and May to 0.84 in October (see also daily DOD records in Fig. S4c). The period July-October partially coincides with the southwest monsoon, occurring from June to September and with the autumn transition covering the period October-November. Middleton (1986) and Smirnov et al. (2002) reported that the dust haze experienced in the Arabian Peninsula from June to August is related to a largescale dust flow originated by the southwest monsoon circulation. As pointed out by Cesnulyte et al. (2014), when validating a previous MACC-II reanalysis, the AOD overestimation during the southwest monsoon period is likely related to a poor representation of rain and aerosol removal processes in MACC-II. When the nine AERONET stations in the Middle East are grouped we find a better correlation between MACC-II and AERONET (0.71), than for the Sahara and the Sahel (0.54), and, in general, better skill scores than in these latter regions (Table 2).

Concerning AE, MACC-II reproduces fairly well the month-to-month variation, matching the AERONET AE values during the first half of the year (January-July), but failing in the period August-December when a notable underestimation $(<50 \%$ of the AERONET AE) is observed (Fig. 6i). From March to June, where the maximum AOD and DOD values are observed, very low AERONET and MACC-II AE values $(\sim 0.1)$ are observed at Solar Village, indicating the presence of coarse particles, clearly associated with desert dust (Eck et al., 1999; Kim et al., 2007; Basart et al., 2009). However, from August to November, Solar Village might be affected simultaneously by the north-westerly flow over the Arabian Peninsula transporting very dry and dust-loaded air from the deserts of Iraq and southern Iran (Liu et al., 2000) and by regional sea-land breeze circulations which cause regional transport of polluted and humid air masses from Persian Gulf to inland regions (Eck et al., 2008), resulting in aerosol heterogeneity where coarse mode desert dust aerosols often mix with fine mode pollution aerosols largely produced by the offshore petroleum industry (Basart et al., 2009), possibly affected by aerosol humidification growth (Smirnov et al., 2002; Eck et al., 2008; Basart et al., 2009). These results are confirmed by a notable increase of $\mathrm{AE}$ and fine AOD observed from August to September in the AERONET stations located in the Persian Gulf corridor, such as Kuwait University, Bahrain, Mussafa, and Abu Dhabi (not shown here). The inland transport of fine aerosols driven by regional land-sea breezes might not be well simulated by MACC-II explaining the significant AE underestimation during this period. The agreement between MACC-II and MODIS is excellent, and poorer scores are provided by OMI (Fig. 7c).

\section{Mediterranean}

In the eastern Mediterranean, Sede Boker station (Israel) shows much lower AOD than the stations analysed previously which were near dust sources. The AOD maximum is recorded in April-May, corresponding with maximum MACC-II dust emissions over Egypt, and western Asia (Fig. 1b), and a secondary maximum is observed from $\mathrm{Au}-$ gust to October (Fig. 6j). MACC-II follows rather well the AOD annual course observed by AERONET, better than MODIS and OMI do, which overestimate excessively. When considering DOD, the agreement between MACC-II and AERONET is excellent, and the secondary maximum is smoothed (Fig. 6k). At the level of daily records, MACCII captures very well all DOD peaks (Fig. S4d). This station shows very high correlations $(r>0.8)$ in two periods, from February to April, and from July to October. The lowest correlation (0.35) is found in January when the mean AERONET DOD is very low (0.04). The lowest FGE is found in July and August (0.29) and the maximum, as expected, in January (0.82). In spring we have the maximum contribution of coarse particles associated with Saharan dust long-range transport and also with uplifted dust particles from the surrounding Negev desert (Andreae et al., 2002; Kubilay et al., 2003; Derimian et al., 2006). This agrees well with the minimum in $\mathrm{AE}$ observed from March to May (Fig. 61). The secondary AOD maximum coincides with a sharp increase in $\mathrm{AE}(>1)$, which is consistent with the coexistence of mineral dust and fine pollution aerosols in Israel when wet removal is practically absent and the accumulation of pollution is favoured (Basart et al., 2009). MACC-II nicely captures the differential behaviour of the month-tomonth variation of AOD and DOD, both in time and magnitude. However AE is underestimated significantly from August to December (Fig. 6l) as a consequence of fine aerosols presence. MACC-II, in comparison with MODIS and OMI, shows the best scores in all seasons (Fig. 7d).

In the western Mediterranean, we have analysed Granada station. This is an urban site located in the southern part of the city of Granada (Spain) situated in the south eastern part of the Iberian Peninsula, surrounded by mountains of high elevation (Alados-Arboledas et al., 2008). This station shows low AOD values through the year and is slightly affected by episodic Saharan dust outbreaks mainly in summertime (Basart et al., 2009; Lyamani et al., 2010). AERONET and MACC-II show a major AOD maximum from July to September and a secondary maximum in February. The agreement between MACC-II and AERONET is quite good, better than that found between AERONET and satellite records (Fig. $6 \mathrm{~m}$ ). The DOD annual courses from AERONET and MACC, again in good agreement each other, are quite similar to that of AOD but with clearly lower values (Fig. 6n). Daily DOD records show that MACC-II is able to correctly simulate every dust intrusion from North Africa (Fig. S3e). 
The maximum correlation coefficients are found in summer (June-August), with monthly values $\geq 0.88$, period in which the maximum DOD $(\geq 0.08)$ is observed. In July and August the lowest FGE ( 0.40 and 0.56 , respectively) are recorded. This coincides with the maximum MACC-II dust emissions in north Algeria (Fig. 1c). The lowest correlation $(0.32)$ is found in November, associated with very low DOD (0.03), and a relatively high FGE (1.02). The AE indicates dominance of fine particles at Granada during all seasons (Fig. 6o). The proportion of fine particles increases in winter, while that of coarse particles increases in summer, in agreement with Lyamani et al. (2010). The small AOD/DOD peaks found from July to September, and in February, correspond to relatively low AE monthly averages $(<0.7)$. The highest discrepancies in $\mathrm{AE}$ are found in wintertime coinciding with the lowest AOD values, justifying the hypothesis that MACC-II misrepresents the $\mathrm{AE}$ at this time of year due to the increase in local anthropogenic emissions (domestic heating) having a larger impact on the fine particles (Lyamani et al., 2010). With these results, we have to emphasize that, in spite of the predominantly urban nature of this station, clearly reflected by relatively high values of AE, MACC-II is able to capture the slight signatures of the Saharan dust intrusions over the station both in the AOD/DOD and AE. MODIS and OMI show a similar performance, but MACC-II clearly shows the best scores in all seasons (Fig. 7e).

When the AERONET stations are grouped, the statistics show a lower correlation in the central Mediterranean (0.60) than in the western and eastern Mediterranean ( 0.80 and 0.81 , respectively) (Table 2). The RMSE over this region (0.16) is higher than in the other two Mediterranean regions $(\leq 0.09)$ (Table 2). These results might be explained by the fact that (1) dust emissions in Libya are weaker than in the rest of North Africa (Fig. 1), (2) the number of dust intrusions is lower over the central Mediterranean, and (3) the distance between North Africa and the stations are notably shorter, which might result in a lower efficiency of MODIS AOD data assimilation.

\section{Subtropical North Atlantic Ocean}

The subtropical region is a well-known Saharan dust transport corridor, mainly in summertime (Prospero et al., 1995; Engelstaedter et al., 2006), so it is a good testing bench to evaluate the performance of MACC-II in situations of dust transport. Santa Cruz de Tenerife (SCO), is a station located in Tenerife, Canary Islands, it monitors marine aerosols within the marine boundary layer (MBL) and mineral dust during Saharan outbreaks.

The AOD annual course from MACC-II tracks well that observed by AERONET and MODIS. A slight overestimation in MACC-II and MODIS is observed in July and August when the maximum AOD is recorded as a result of a higher dust intrusions frequency. The agreement between MACC-II and MODIS is excellent (Fig. 6p), most likely be- cause the data assimilation from MODIS is successful over the ocean, once the dust cloud is accurately identified by MODIS. The agreement of MACC-II-AERONET in DOD is also excellent showing the maximum DOD in summer, and a secondary maximum in March (Fig. 6q), in agreement with Alonso-Pérez et al. (2007) and Basart et al. (2009). The daily DOD records from AERONET and MACC-II show good agreement. MACC-II shows skill in simulating single dust events in time and in magnitude (Fig. S3f). We find similar skill scores in the north-western Maghreb region as it is also a Saharan dust outflow corridor (Table 2). The annual course of MACC-II AE follows that observed by AERONET with a marked minimum $(<0.3)$ in summer coinciding with the maximum dust transport over the Canary Islands. When subtracting monthly DOD averages from monthly AOD values, we have a rough estimate of the AOD corresponding to marine aerosols of $\sim 0.1$, which agrees with Smirnov et al. $(2009,2011)$ who found an AOD associated to marine aerosols in open ocean $<0.1$.

MODIS shows the best scores (Fig. 7f). MACC-II shows a similar behaviour to that of MODIS in summer, when the major dust intrusions are recorded, and in autumn. OMI clearly departs from the performance of MODIS and MACCII.

\subsection{Extinction vertical profiles}

In this study, we also analyse the ability of MACC-II in reproducing climatological dust vertical distribution instead of evaluating its skill to reproduce single extinction vertical profiles.

The extinction vertical profiles simulated by MACC-II (at $550 \mathrm{~nm}$ ) over M'Bour and SCO on those days with predominant dust aerosols over each station (AERONET AE $\leq 0.35$ at M'Bour and AERONET AE $\leq 0.75$ at $\mathrm{SCO}$ ) were averaged for each month and for seasons, during 2007-2008, and compared with the corresponding averaged extinction profiles from ground-based lidar at each site. Since a high number of cases of mineral dust mixed with biomass burning aerosols occurred at M'Bour, while IZO is completely free from biomass burning aerosols, we have imposed a more restrictive AE threshold at M'Bour data in order to assure almost pure mineral dust conditions. We emphasize that this study is specific to almost pure dust conditions, so the results may differ from other studies that have not been considered restrictive filters to retain only dust conditions.

CALIOP vertical profiles were also analysed and compared with MACC-II at SCO and M'Bour. CALIOP extinction profiles at $532 \mathrm{~nm}$ within circles of $1.5^{\circ}$ radius centred in M'Bour and Santa Cruz de Tenerife (lidar stations) were retrieved for the period 2007-2008. This distance, lower than that used by Tesche et al. (2013), $\sim 2.5^{\circ}$, for the CALIOP observations calibration of dust and smoke over Cape Verde, is reasonable, and a good agreement is expected between CALIOP and ground observations (Tesche et al., 2013, and 
references herein). To filter the noise, CALIOP profiles were smoothed in the vertical, yielding values for intervals of $300 \mathrm{~m}$ from the surface to $8 \mathrm{~km}$ (Cavalieri et al., 2010). Furthermore, we must bear in mind the considerable constraints of this intercomparison in relation to the presence of clouds. CALIOP data correspond to a circular area of $1.5^{\circ}$ radius around the ground-based lidar, and therefore cloud conditions can be totally different for the lidar and CALIOP at the time of comparison. For this reason, and in order to minimize the potential cloud contamination, we used the median instead of the mean in the CALIOP average profiles. The number of simultaneous profiles of MACC-II and CALIOP decreases notably.

The average particle extinction-to-backscatter ratio, hereinafter referred as the "lidar ratio" (LR) is defined as

$\mathrm{LR}=\frac{\alpha_{\mathrm{a}}}{\beta_{\mathrm{a}}}$.

Where $\alpha_{\mathrm{a}}$ is the aerosol extinction coefficient and $\beta_{\mathrm{a}}$ is the aerosol backscattering coefficient. The CALIOP aerosol extinction coefficient (at $532 \mathrm{~nm}$ ) values are calculated with a lidar ratio of $40 \mathrm{sr}$ (Winker et al., 2009), higher than the averaged lidar ratio obtained from ground-based lidars $(\sim$ $30 \pm 10 \mathrm{sr}$ ) at M'Bour (Mortier et al., 2013) and SCO, and slightly higher than that obtained by Omar et al. (2010) at Cape Verde (35.7 sr) for a dust layer.

\subsubsection{Extinction vertical profiles over M'Bour (Senegal)}

In order to ensure that the extinction vertical profiles corresponded to conditions in which the prevailing aerosol was desert dust, we only selected those extinction profiles corresponding to $\mathrm{AE}<0.35$ provided by the Dakar AERONET sunphotometer (located some $80 \mathrm{~km}$ from M'Bour), and then, they were grouped in different seasons according to their similarity. We use a rather restrictive value of $\mathrm{AE}$ in order to almost completely discard the days with biomass burning aerosols, especially in winter (León et al., 2009). A total of 686 extinction profiles met this requirement during 2007-2008. Note that, for the selected cases, seasonal AE averages are $<0.22$, indicating that we have almost pure dust conditions. In fact, MACC-II total and natural averaged extinction profiles are nearly coincident in the free troposphere over $1 \mathrm{~km}$ altitude in all seasons (Fig. 8a-d).

The months included in each season do not necessarily agree with those used by other authors for this site (e.g. Léon et al., 2009; Cavalieri et al., 2010; Schmechtig et al., 2011; Mortier, 2013). In our case, the four seasons are the dry season (November-March), driven by the Harmattan winds, spring (April-May), the wet period (June-August), basically driven by the monsoon, and autumn (September-October). The averaged extinction vertical profiles of MACC-II and lidar for the different seasons show distinct characteristics in terms of mineral dust vertical distribution (Fig. 8a-d). Re- garding the comparison with simultaneous CALIOP extinction vertical profiles, we must point that the number of profiles used in the averages is notably lower (Fig. 8e-h); therefore, the averaged vertical profiles are noisier.

It should be noted that the interannual variability in the concentration of different types of aerosols over M'Bour is rather large (León et al., 2009; Mortier, 2013), so the statistics presented below are not intended to have climatological significance, but rather to show the average characteristics of the different seasons for the period 2007-2008. In general, a well-defined MBL is observed from lidar extinction profiles in all seasons with a high extinction $\left(>0.2 \mathrm{~km}^{-1}\right)$ and a rather constant top ( $\sim 1 \mathrm{~km}$ altitude), in agreement with León et al. (2009). It is noteworthy that a mixture of marine aerosols and desert dust takes place within the MBL (Groß et al., 2011; Tesche et al., 2011).

A significant result is that MACC-II does not match the observed extinction within the MBL (Fig. 8a-d). Similar results are found with CALIOP vertical profiles, although CALIOP intensifies even more the extinction peak in the MBL in summer and autumn (Fig. 8g and h). However, these differences between MACC-II and the ground-based lidar might be explained, at least partially, by an artefact of lidar extinction retrieval. The lidar ratio applied in these profiles follows a "single-layer" approach, which uses a variable lidar ratio that is selected for each profile in order to achieve the best agreement with the AOD provided by a colocated AERONET station. Thus the averaged value of lidar ratio $\sim 30 \mathrm{sr}$ is too high for marine aerosols present in the MBL (below $1 \mathrm{~km}$ ), since the lidar ratio corresponding to marine aerosols is $\sim 20 \mathrm{sr}$ (Doherty et al., 1999; Winker et al., 2009; Schuster et al., 2012), resulting in an overestimation of the observed extinction within the MBL. Results found by Groß et al. (2011) and Tesche et al. (2011) show that in Cape Verde, close to M'Bour, the MBL contained marine aerosol mixed with dust in winter, and pure marine aerosol in summer. This is consistent with the fact that extinction from MACC-II fitted well to that observed by lidar within the MBL in winter (Fig. 8a), whereas in summer there is a big difference (Fig. 8c).

Above the MBL we observe the impact of desert dust into the free-troposphere. The top of the dust layer, referred to as top layer (TL) according to León et al. (2009), changes according to the season.

During the dry season (250 paired vertical profiles from November to March), in wintertime, we find an excellent agreement between MACC-II and lidar (Fig. 8a). This season is characterized by the presence of biomass burning aerosols confined in the upper layers (free-troposphere), according to Haywood et al. (2008) and Cavalieri et al. (2010). However, we expect to have filtered out most of this contribution. The mean AERONET AOD 550 for dust events in this season is $0.45 \pm 0.22(\mathrm{AE}=0.21 \pm 0.08)$. The vertical profile is a monotonous decrease of extinction with altitude from 1 to $5 \mathrm{~km}$, in which the extinction values above the 50th percentile 

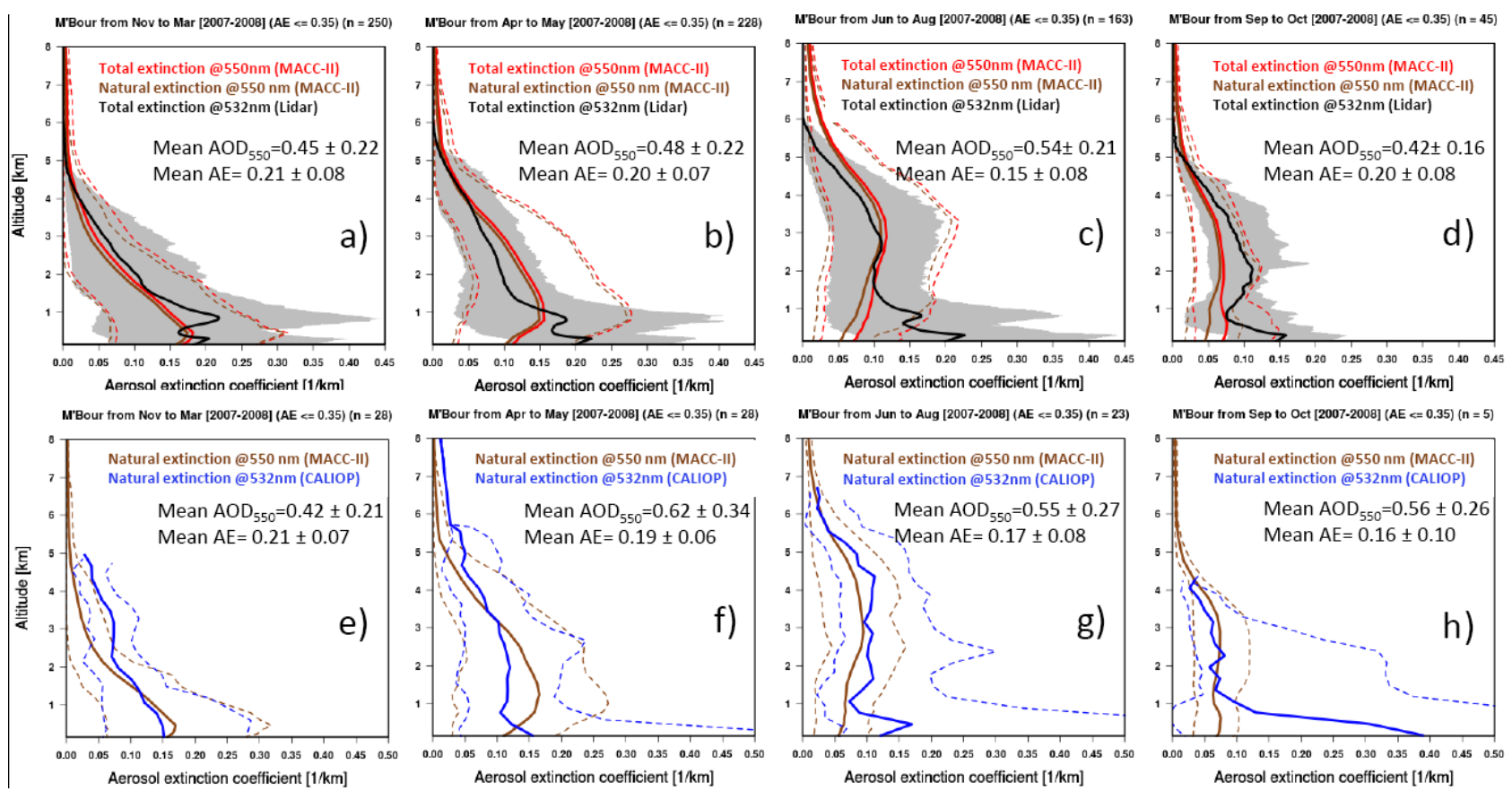

Figure 8. Averaged extinction coefficient vertical profiles obtained with simultaneous extinction profiles simulated with MACC-II and observed by the lidar at M'Bour for those days with mean $\mathrm{AE}<0.35$, for the following periods: November-March (a), November-May (b), June-August (c), and September-October (d). MACC-II natural extinction corresponds to marine and dust aerosols. The gray shaded area is bounded by the 10th and 90th percentile values of ground-based lidar total extinction at each level. Panels (e-h) are the same as previous ones but using CALIOP extinction vertical profiles. Dashed lines indicate the 10th and 90th percentile values of MACC-II and CALIOP natural extinction at each level.

(up to $2 \mathrm{~km}$ altitude), fall in the range $0.1-0.2 \mathrm{~km}^{-1}$, which corresponds to moderate dust load (Cavalieri et al., 2010). CALIOP agrees with MACC-II until $2 \mathrm{~km}$ altitude. Above this level CALIOP shows some overestimation compared with MACC-II.

In spring (228 paired vertical profiles in April-May) a slight increase in extinction is observed between 1.5 and $4 \mathrm{~km}$ altitude (Fig. 8b), corresponding to a slight increase in mean $\mathrm{AOD}_{550}(0.48 \pm 0.22)(\mathrm{AE}=0.20 \pm 0.07)$, which agrees with Mortier (2013), who found a clear influence of desert sources at $3 \mathrm{~km}$ altitude in this season. MACCII shows some overestimation between 1.5 and $4 \mathrm{~km}$ altitude $\left(\Delta \alpha_{\mathrm{a}} \approx 0.025-0.05 \mathrm{~km}^{-1}\right)$ compared with both groundbased lidar and CALIOP.

In the wet season (163 paired vertical profiles from June to August) the bulk of the aerosol vertical distribution is found between 2 and $3 \mathrm{~km}$ altitude (Fig. 8c), indicating that the free troposphere over M'Bour is clearly under the influence of Saharan dust. The mean $\mathrm{AOD}_{550}$ increases up to $0.54 \pm 0.21$ $(\mathrm{AE}=0.15 \pm 0.08)$. During this season, desert dust is transported within the SAL at an altitude between 2 and $5 \mathrm{~km}$ (Prospero and Carlson, 1981; Pelon et al., 2008; Tsamalis et al., 2013). In fact the SAL is clearly observed by both lidar and MACC-II between 1.5 and $6 \mathrm{~km}$ altitude (TL), laying extinction values above the 50th percentile within the range $\left(0.1-0.2 \mathrm{~km}^{-1}\right)$ between 1.5 and $3.5 \mathrm{~km}$. Furthermore, we ob- served a clear increase in extinction between 4 and $6 \mathrm{~km}$ altitude with respect to spring, which is explained by Mortier (2013) by a delayed impact of dust sources at $\sim 5 \mathrm{~km}$ altitude, using air mass backward trajectory analysis. In general, MACC-II shows an excellent agreement with the lidar in the free troposphere in this season, representing very satisfactorily the SAL in both altitude and magnitude. The averaged extinction vertical profile for this season is rather overestimated by CALIOP compared with MACC-II from the ground to $7 \mathrm{~km}$ altitude, although the shape of the vertical extinction profile is quite similar to that of the lidar (Fig. 8g).

Finally, in autumn (45 paired vertical profiles from September to October), we observe the minimum extinction in low levels of all seasons, and an extinction maximum centred at $\sim 2 \mathrm{~km}$ altitude (Fig. 8d), corresponding with a minimum mean value of $\mathrm{AOD}_{550}(0.42 \pm 0.16)$ $(\mathrm{AE}=0.20 \pm 0.08)$. In this case, although MACC-II captures rather well the dust vertical structure, this is underestimated ( $\Delta \alpha_{\mathrm{a}} \approx-0.05 \mathrm{~km}^{-1}$ ) up to $4 \mathrm{~km}$ altitude. On the contrary, the CALIOP extinction vertical profile shows a good agreement with MACC-II, except in the MBL (Fig. 8h).

We can conclude that a rather good agreement between lidar, MACC-II and CALIOP is found at M'Bour station, although a slight overestimation is observed in CALIOP in upper levels and the MBL. This agrees with Amiridis et al. (2013) who reported CALIOP extinction 
Table 3. Lidar ratios (LR) at SCO station when AE $\leq 0.75$, for different periods during 2007-2008.

\begin{tabular}{lcc}
\hline Period & LR (sr) & \# of profiles \\
\hline Dec-Feb & $29.80 \pm 10.58$ & 73 \\
Mar-Apr & $30.20 \pm 10.73$ & 105 \\
May-Jun & $30.47 \pm 8.23$ & 29 \\
Jul-Sep & $31.30 \pm 11.29$ & 129 \\
Oct-Nov & $30.50 \pm 11.17$ & 56 \\
\hline
\end{tabular}

overestimation, compared with BSC-DREAM8b model, above 5 and below $1 \mathrm{~km}$ for CALIOP Version I (lidar ratio of $40 \mathrm{sr}$ ), increasing this overestimation for CALIOP Versions II and II (lidar ratio of $58 \mathrm{sr}$ ), specifically in the Sahel region. Comparing with other model validation exercises, the agreement between MACC-II and the lidar is better than that found by Mortier (2013) between NMMB/BSC-Dust model and the lidar at M'Bour during summer 2007.

\subsubsection{Extinction vertical profiles over SCO (the Canary Islands)}

For SCO we have established five periods: the winter season (from December to February), the early spring season (from March to April) when the Saharan dust outbreaks occur at low altitude (up to $\sim 2 \mathrm{~km}$ ) intruding the MBL (AlonsoPérez et al., 2007), the late spring season (from May to June), characterized by clean atmosphere with sporadic dust intrusions, the summer season (from July to September) when the SAL intrudes the free troposphere above the MBL (Rodríguez et al., 2011; Cuevas et al., 2013), being normally detected between 1 and $6 \mathrm{~km}$ altitude (Andrey et al., 2014), and the autumn season (from October to November) with again very sporadic dust intrusions. In the case of SCO we have selected those extinction profiles in which the collocated AERONET sunphotometer at SCO measured $\mathrm{AE}<0.75$, in order to select days of Saharan air intrusions rich in desert dust (Basart et al., 2009). A total of 336 extinction profiles met this criterion. The AE threshold value is significantly less restrictive than that used in M'Bour because there is no contamination with biomass burning aerosols over the Canary Islands. The lidar ratio at $523 \mathrm{~nm}$ averaged for those extinction profiles with $\mathrm{AE}<0.75$ is $\sim 30 \pm 10 \mathrm{sr}$ (see Table 3 ) for the five seasons in SCO. This value is the same as that obtained at M'Bour under dust conditions.

The first notable feature is, like at M'Bour site, the presence of a layer with relatively high extinction values $(0.05-$ 01) within the MBL, below $1 \mathrm{~km}$ altitude (Fig. 9a-d). In the region of the Canary Islands, the MBL is very stable throughout the year and is characterized by a high content of marine aerosols, although at a lower concentration than in M'Bour. MACC-II captures the extinction maximum within the MBL better than in M'Bour, though it is slightly underestimated. As in the case of M'Bour, we speculate extinction is somewhat overestimated by lidar within the MBL because of the lidar ratio used in the "single-layer" inversion approach. As we did for M'Bour, we have calculated the average of the simultaneous CALIOP extinction vertical profiles with MACC-II profiles for each season (Fig. 9e-h).

In wintertime we find a good agreement in extinction vertical distribution between MACC-II and the lidar in the free troposphere over Tenerife (73 paired vertical profiles from December to February) (Fig. 9a). During this season the presence of dust is rare and it is observed at low levels, being well simulated by MACC-II. The mean $\mathrm{AOD}_{550}$ associated with dusty days is $0.19 \pm 0.13(\mathrm{AE}=0.47 \pm 0.17)$, less than half of the average value recorded at M'Bour in winter. CALIOP shows a slight overestimation in upper levels and the MBL, compared with MACC-II, probably caused by cloud contamination (Fig. 9e).

In early spring (105 paired vertical profiles from March to April) low-level Saharan dust outbreaks intruding the MBL and affecting the population living in areas close to the coast are recorded almost every year, although there is a great interannual variability (Viana et al., 2002; Alonso-Pérez et al., 2007). During this season, dust intrusions may impact significantly up to $\sim 3 \mathrm{~km}$ altitude (Fig. 9b), resulting in a mean $\mathrm{AOD}_{550}$ of $0.22 \pm 0.14(\mathrm{AE}=0.38 \pm 0.15)$ during dusty days. Again, a rather good agreement in the shape of the extinction vertical profiles between MACC-II and lidar is found although with some overestimation by MACC-II. For CALIOP and, as in the dry season, a slight overestimation is found compared with MACC-II (Fig. 9f).

Late spring (29 paired vertical profiles from May to June) is the cleanest period in which very few dust intrusions occur. However, when some dust outbreaks sporadically occur, their vertical structure resemble those recorded in summertime, reaching higher levels (up to $\sim 6 \mathrm{~km}$ altitude) than those recorded in early spring (Fig. 9c). The mean $\mathrm{AOD}_{550}$ corresponding to days with dust intrusions decreases to $0.16 \pm 0.10$ $(\mathrm{AE}=0.49 \pm 0.20)$. In this season, the agreement of the MACC-II-lidar is fairly good. CALIOP, again, shows the same shape of the averaged extinction vertical profile, but somewhat overestimated (Fig. 9g).

Finally the most interesting season in terms of dust impact is summertime (129 paired vertical profiles from July to September). During this season the SAL frequently intrudes the subtropical free troposphere (Karyampudi et al., 1999) and clearly impacts the lower free troposphere, from $\sim 1$ to $\sim 6 \mathrm{~km}$ over Tenerife (Cuevas et al., 2013; Rodríguez et al., 2014) with high dust content and relatively high humidity (Andrey et al., 2014). The maximum extinction is found between 2 and $3 \mathrm{~km}$ altitude (Fig. 9d). The mean $\mathrm{AOD}_{550}$ in dusty days is $0.21 \pm 0.10(\mathrm{AE}=0.37 \pm 0.15)$, similar to that found in spring under dust conditions. MACC-II reproduces quite well the extinction vertical structure in both shape and magnitude. In this case, CALIOP shows a slight overestimation along the entire vertical profile compared with MACC-II (Fig. 9h). 

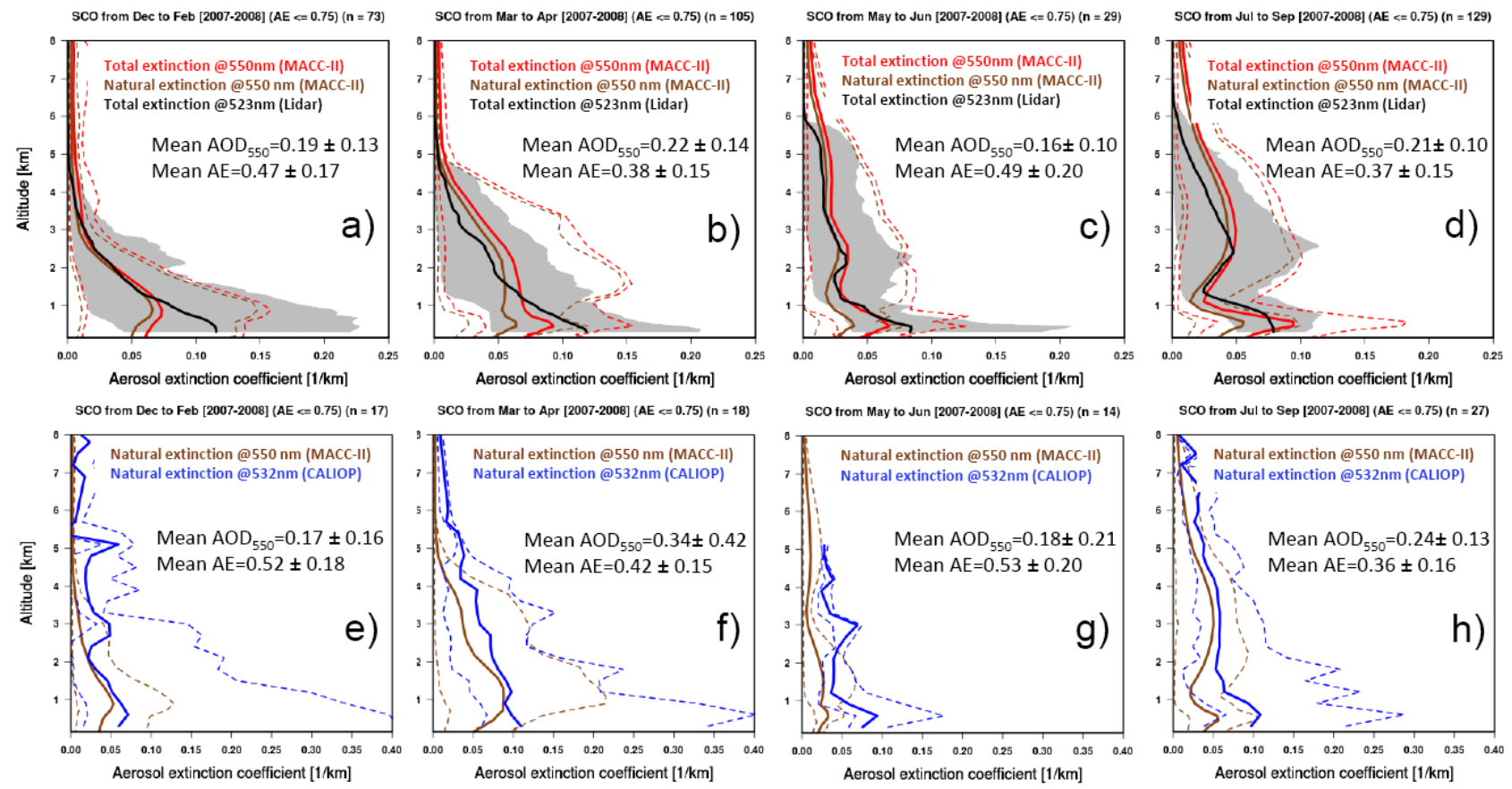

Figure 9. The same as Fig. 8 but for SCO station, and corresponding periods, where AE $<0.75$ was used, instead $<0.35$, to select dust days.

We highlight that the comparison with CALIOP is not trivial, and that much of the observed differences between CALIOP and MACC-II might be due to a number of varied causes addressed by Burton et al. (2013) and Amiridis et al. (2013) and references herein. Some of them are misclassification of aerosol type and failure to identify different aerosol types within a column (which could have great significance at M'Bour), errors in modelled lidar ratios for particular aerosol types, unsuitable averaging technique of CALIOP extinction vertical profiles, cloud contamination, and the uncertainty of CALIOP extinction profiles. A specific comparison with CALIOP by using a more refined CALIOP data selection methodology, such as that used by Amiridis et al. (2013), would be necessary.

\subsection{Ground-surface dust concentration}

Surface dust daily mean concentrations from MACC-II reanalysis have been evaluated with daily averaged $\mathrm{PM}_{10}$ at three monitoring stations (Fig. 2) provided by the AMMA project (Marticorena et al., 2010; see Sect. 3.13). This is an interesting test region where $\mathrm{PM}_{10}$ concentrations can vary very quickly from $<10$ to $>2000 \mu \mathrm{g} \mathrm{m}^{-3}$. This feature can be easily seen in the daily $\mathrm{PM}_{10}$ records of the three AMMA stations depicted in Fig. S5. Furthermore, the quasi permanent presence of aerosols from biomass burning, during the dry season, and marine aerosols in the case of M'Bour, represent a challenge for mineral dust evaluation.

The selection of $\mathrm{PM}_{10}$ data by wind sectors, as previously reported by Marticorena et al. (2010), results in enough data only during the dry season, and very few data in the rest of the year, preventing an adequate assessment of MACCII surface dust concentration. The technique used for $\mathrm{PM}_{10}$ measurements at the three AMMA stations can volatilize seasalts and organic components of carbonaceous aerosols and thus maximize the contribution of mineral dust to the $\mathrm{PM}_{10}$ concentrations (Marticorena et al., 2010). Moreover, maximum $\mathrm{PM}_{10}$ from marine aerosols is not expected to exceed $30 \mu \mathrm{g} \mathrm{m}^{-3}$ (Viana et al., 2002; Zhou et al., 2013), and $\mathrm{PM}_{10}$ corresponding to biomass burning aerosols in the Sahel region is normally below $30 \mu^{-3} \mathrm{~g}^{-3}$ (Capes et al., 2008; Zhou et al., 2013). Considering all of the above, we conclude that non-dust aerosols do not introduce a significant bias in the MACC-II evaluation.

The monthly evolution of recorded $\mathrm{PM}_{10}$ and MACC-II surface dust concentration at the three AMMA stations during the period 2007-2008 is shown in Fig. 10. Unlike the seasonal pattern in AOD/DOD, where a maximum is observed in April-May (Fig. 6d and e), the maximum in $\mathrm{PM}_{10}$ is observed somewhat earlier, at the end of winter and early spring. Thus the AOD/DOD and $\mathrm{PM}_{10}$ series are out of phase.

MACC-II underestimates monthly means throughout the year and especially in winter and early spring (dry season) when Saharan dust is transported by Harmattan winds. This is also observed in the results of the vertical profiles comparison in Sect. 4.2. During the dry season, the dust variability recorded along the stations transect reflects the variability in dust emission by different Saharan sources (Marticorena et al., 2010). This zonal gradient, with higher $\mathrm{PM}_{10}$ 

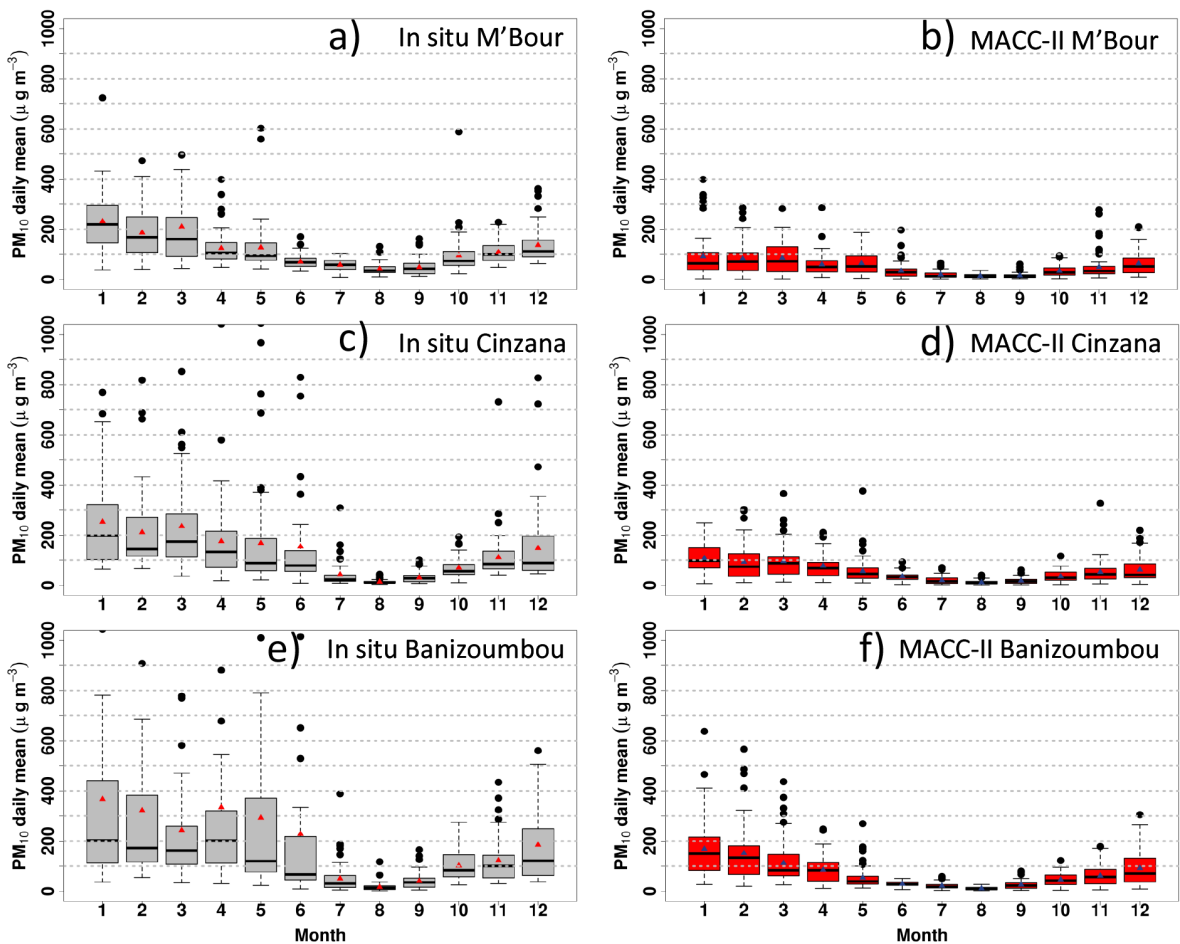

Figure 10. Monthly box-plots of surface dust concentration simulated by MACC-II and $\mathrm{PM}_{10}$ observed by AMMA stations during the period 2007-2008 at M'Bour (a and b), Cinzana (d and e), and Banizoumbou (e and $\mathbf{f}$ ). Box-plots indicate the following: the bottom and top of the box are the surface dust/ $\mathrm{PM}_{10}$ concentration 25 th and 75 th percentile, the band near the middle of the box is the 50th percentile (the median), and the triangle (red/blue) expresses the surface dust/PM 10 mean value. The ends of the whiskers represent the one SD above and below the mean of the surface dust/PM 10 data. Any data not included between the whiskers is plotted as an outlier with a dot.

values eastward, is well captured by MACC-II (see also Fig. S5). Some sporadic very strong dust events, represented by outliers, particularly intense at Cinzana and Banizoumbou (Fig. 10c and e, S5b and c), modulate the differences between in situ and MACC-II surface dust concentrations in the wet season (summertime). The mean $\mathrm{PM}_{10}$ shows much higher values than the median $\mathrm{PM}_{10}$ in in situ observations (Fig. 10c and e). The reason is that summertime is characterized by extensive and fast convective phenomena resulting in large total attenuated backscattering values which alternate with very clear profiles, sometimes separated by only few hours (Cavalieri et al., 2010). However, these differences are not observed in MACC-II surface dust concentration box-plots (Fig. 10d and f), indicating that MACC-II does not capture most of these strong and fast dust events. During this period the north-easterly advancement of the monsoon creates unstable atmospheric conditions and the formation of thunder cells and squall lines may lead to the development of strong downdraughts generating, sometimes, spectacular dust walls (Gillies et al., 1996; Knippertz et al., 2009). According to Marticorena et al. (2010) the summer dust events are mainly controlled by local surface wind velocity and thus most of them result from mesoscale convective systems favouring local dust emissions. The poor performance of MACC-II in capturing these mesoscale processes is largely explained by the MACC-II coarse spatial resolution and by the fact that MACC-II uses convective parameterizations where downdrafts are not simulated.

We computed the skill scores of the comparison of paired daily data MACC-II-AMMA stations for the period 2007 2008 , for each of the three stations, for the entire period, for the period November-March, corresponding to the dry season in which the highest $\mathrm{PM}_{10}$ values are recorded, and for the period June-August centred in the rainy season when the lowest $\mathrm{PM}_{10}$ values are observed (Table 4). It is necessary to note that observational parameters do not correspond exactly with the corresponding modelled parameters (size bins used to estimate surface dust concentration). Furthermore, $\mathrm{PM}_{10}$ data selection aimed to select periods during which dust transport can be considered as the main contributor. However, the filtering procedure used in AMMA stations cannot assure all observed $\mathrm{PM}_{10}$ corresponds only to dust.

The correlation coefficients show a marked seasonal variation, with higher values in the dry season and lower values in summertime affected by regional mesoscale convective systems from monsoon regime. The correlation coefficient is moderate in M'Bour $(r>0.52)$ in all three periods, high at Cinzana and Banizoumbou during the dry season 
Table 4. Skill scores quantifying the level of agreement between MACC-II surface dust concentrations and AMMA-PM 10 daily means for 2007-2008.

\begin{tabular}{lccccccc}
\hline Station & & MB & MNMB & FGE & RMSE & $r$ & $n$ \\
\hline \multirow{2}{*}{ M'Bour } & Total & -68.71 & -0.90 & 0.92 & 110.85 & 0.63 & 731 \\
& Nov-Mar & -99.84 & -0.89 & 0.90 & 152.71 & 0.52 & 303 \\
& Jun-Aug & -34.57 & -0.98 & 1.00 & 41.66 & 0.57 & 184 \\
\hline \multirow{2}{*}{ Cinzana } & Total & -81.19 & -0.67 & 0.74 & 158.72 & 0.67 & 704 \\
& Nov-Mar & -109.58 & -0.76 & 0.79 & 170.85 & 0.76 & 303 \\
& Jun Aug & -52.67 & -0.56 & 0.70 & 157.83 & 0.29 & 157 \\
\hline \multirow{2}{*}{ Banizoumbou } & Total & -120.02 & -0.62 & 0.74 & 310.17 & 0.56 & 727 \\
& Nov-Mar & -130.77 & -0.57 & 0.68 & 264.54 & 0.81 & 300 \\
& Jun-Aug & -75.89 & -0.57 & 0.72 & 259.46 & 0.29 & 183 \\
\hline
\end{tabular}

$(>0.75)$, and low in the last two stations during the wet season $(<0.30)$ because these stations are the most influenced by mesoscale convective systems.

The FGE ranges between 0.68 and 0.79 in Cinzana and Banizoumbou in the three periods, and from 0.9 to 1.0 in M'Bour. The MNMB is from -0.57 to -0.76 in Cinzana and Banizoumbou for the three periods, and significantly higher in M'Bour, with values ranging from -0.89 to -0.98 . These scores are somewhat better than those reported by Schmechtig et al. (2011) when comparing daily data of simulated aerosol surface concentration by the regional CHIMERE model with $\mathrm{PM}_{10}$ observations at the same three sites, but in a different period (2006). In the case of M'Bour, this observatory is located less than a hundred metres from the Atlantic Ocean and south of the town of M'Bour, hence is subjected almost daily to the sea breeze transporting sea spray and to particles of anthropogenic origin (Marticorena et al., 2010); this explains the worse skill scores reported by both MACC-II and CHIMERE models in this station.

To make a proper assessment of the obtained skill scores we have used, as did Schmechtig et al. (2011), we have compared our skill scores to the "model performance goal" (the level of accuracy that is considered to be close to the best a model can be expected to achieve) and "model performance criteria" (the level of accuracy that is considered to be acceptable for modelling applications) established by Boylan and Russel (2006) for PM. According to Boylan and Russel (2006), the model performance goal has been met when both the FGE and the mean fractional bias (corresponding to MNMB in Table A1) are less or equal than +0.5 and \pm 0.3 , respectively, while the model performance criteria has been met when both the FGE $\leq+0.75$ and $\mathrm{MNMB} \leq \pm 0.6$. However, the tested air quality models reported a FGE (for $\mathrm{PM}_{10}$ ) from 0.3 to 1.10 , and a MNMB from -1 to +0.5 for $\mathrm{PM}_{10}$ concentrations in the range of $0-30 \mu \mathrm{g} \mathrm{m}^{-3}$.

The level of agreement between MACC-II surface dust concentration and observed $\mathrm{PM}_{10}$ fulfils the model performance criteria proposed by Boylan and Russel (2006) at Banizoumbou during the three periods, and at Cinzana during the wet season and during the whole period, while in M'Bour FGE and MNMB exceeds the model criteria. These results are rather good for a global reanalysis model, considering the evaluation has been performed in an extremely complex region characterized by frequent mesoscale processes and affected by anthropogenic aerosols, and also by marine aerosols in the case of M'Bour.

\section{Conclusions}

A thorough analysis with an emphasis on dust sources over northern Africa and the Middle East is conducted to evaluate the MACC-II reanalysis dust through the use of AOD from MISR, MODIS and OMI satellite aerosol products, groundbased AERONET data, in situ $\mathrm{PM}_{10}$ concentrations from AMMA, and extinction vertical profiles from two groundbased lidars and CALIOP satellite-based lidar.

The geographic domain selected for the validation of MACC-II 2007-2008 reanalysis comprises two of the most arid desert regions of the Earth, the Sahara and the Middle East, world primary mineral dust sources, as well as oceanic regions (Mediterranean Sea, Atlantic Ocean and Arabian Sea) over which dust clouds are often transported. In this broad region, the dust burden can vary by several orders of magnitude. Dust is mixed with marine aerosols in coastal regions, with biomass burning aerosols in the Sahel, and aerosols from industrial activities in the Middle East and the Mediterranean basin. So, it is a complex geographic domain that constitutes a real test bench to know how MACC-II reanalysis behaves in simulating mineral dust. Our aim was to know to what extent this MACC-II reanalysis is able to correctly simulate mineral dust content variations on daily, monthly, seasonal and interannual basis in different regions.

The agreement between MISR, OMI, MODIS and MACCII is, in general, rather good, reproducing the same AOD spatial patterns. The AOD MACC-II-MISR NMB values fall within 1.4 in most of the study domain in the four seasons, except in the Mediterranean basin, Turkey, Iran and central 
Africa where the ratios are higher. MACC-II-MISR NMB values are larger than 1.4 over central Sahara in spring and summer, which might be caused by dust storms not observed by MISR due to its low temporal resolution. A notable exception is the MACC-II AOD underestimation over the Bodélé depression which might be related to an underestimation of surface wind velocity over this region. MACC-II generally is able to correctly simulate the interannual variations of AOD in each season obtained by satellite observations, albeit smoother. The dust corridor from Iraq to Oman, covering the entire Persian Gulf, is the region in which MACC-II shows greater difficulties to adequately simulate interannual changes in winter and spring compared with satellite observations.

MACC-II AOD and AE have been also quantitatively evaluated by means of the comparison against 26 AERONET stations distributed in different regions. We have used the AERONET (at $500 \mathrm{~nm}$ ) coarse mode AOD from the SDA retrieval as a proxy of DOD. The SDA retrieval gives better skill scores for the model and keeps a larger number of observations for evaluation (i.e. the number of available observations) than if one would use AOD from AERONET in conditions where the $\mathrm{AE}$ is smaller than 0.6 to select AOD corresponding to coarse particulate matter. The MACC-II evaluation against AERONET observations has been performed in a large range of DOD values, with DOD $<0.1$ in dust transport regions, such as the Mediterranean basin and the subtropical North Atlantic, and DOD $>0.35$ in source regions (Sahara and the Middle East). Overall DOD monthly variation is well captured by MACC-II in all regions. The correlation is significantly higher in dust transport regions than in dust source regions and daily DOD value variations show that MACC-II is able to correctly simulate dust intrusions from northern Africa to both the Mediterranean basin and the North Atlantic Ocean. This is particularly true in summer, when the highest dust activity is observed over the Sahara. In the Middle East MACC-II overestimated DOD from July to October, which might be likely related to a poor representation of rain and removal processes in MACC-II. For the Ångström Exponent, in general, the seasonal variation is well captured by MACC-II in all regions, but a significant underestimation is observed with differences ranging from 0.1 to 0.5 . The lowest correlations between MACC-II and AERONET DOD are found in the Sahara and Sahel (0.54). In the rest of the regions a moderate to good correlation $(r>0.60)$ is found, being relatively high in dust transport regions $(r>0.80)$. In the Sahara and Sahel the lowest correlation is registered in summer $(r<0.50)$ when the maximum dust activity is observed associated with the development of mesoscale convective processes modulated by the monsoon.

We have assessed the ability of MACC-II in reproducing dust vertical profiles. We averaged those extinction vertical profiles simulated by MACC-II (at $550 \mathrm{~nm}$ ) over M'Bour and SCO coincident with extinction profiles obtained with lidar instruments at each station, respectively, un- der dust conditions (AERONET AE $<0.35$ at M'Bour and AERONET AE $<075$ for SCO) for each month and season, during 2007-2008. CALIOP extinction vertical profiles $(532 \mathrm{~nm})$ have been compared with MACC-II. We find a good agreement in dust layers structures and averaged extinction vertical profiles between the lidars (at M'Bour and SCO), MACC II, and CALIOP above de MBL from 1 to $6 \mathrm{~km}$ altitude in all seasons, although a slight overestimation is observed in CALIOP. Several causes could explain this overestimation such as a wrong classification of aerosol type, failure to identify different aerosol types within a column, errors in modelled lidar ratios, inadequate averaging technique of extinction vertical profiles, and cloud contamination, among others. Furthermore, our CALIOP data correspond to a circular area of $1.5^{\circ}$ radius around the ground-based lidar, and therefore dust and cloudy conditions might be totally different in some events for the lidar and CALIOP at the time of comparison. A well-defined MBL is observed from lidar extinction profiles in all seasons with a high extinction $\left(>0.2 \mathrm{~km}^{-1}\right)$ and a rather constant depth $(\sim 1 \mathrm{~km}$ altitude $)$ in both stations. Similar results are found with CALIOP vertical profiles. MACC-II does not match the observed extinction within the MBL. However, we must bear in mind that lidars provide no credible data in the first hundred metres due to overlap and after pulse limitations, and that extinction overestimation might be caused by the use of a relatively high lidar ratio in the MBL.

Surface dust daily mean concentrations from MACC-II reanalysis has been evaluated with daily averaged $\mathrm{PM}_{10}$ at three monitoring stations of the Sahelian Dust Transect during 2007 and 2008. MACC-II underestimates monthly means all year long and especially in winter and early spring (dry season) when Saharan dust is transported by the Harmattan winds. During the dry season MACC-II captures well the dust variability recorded along the stations transect which reflects the variability in dust emission by different Saharan sources. Some sporadic and very strong dust events mainly affected Cinzana and Banizoumbou, modulating the differences found between in situ and MACC-II surface dust concentrations in the wet season (summertime). MACC-II does not capture most of these strong and fast dust events, which are associated to mesoscale convective systems. The poor performance of MACC-II for these events is largely explained by the spatial resolution and by the fact that MACCII uses parameterizations where downdrafts are not simulated. The correlation coefficients show a marked seasonal variation, with higher values in the dry season and lower values in summertime. The level of agreement between MACCII surface dust concentration and observed $\mathrm{PM}_{10}$ fulfils the model performance criteria (the level of accuracy that is considered to be acceptable for modelling applications) at Banizoumbou during the three periods, and at Cinzana during the wet season and during the whole period, while M'Bour exceeds the model criteria. However, it is necessary to note that observational parameters $\left(\mathrm{PM}_{10}\right)$ do not correspond exactly 
with the corresponding modelled parameters (size bins to estimate surface dust concentration), and that all observed $\mathrm{PM}_{10}$ do not correspond only to dust.

The evaluation of mineral dust is a complex task because dust is one of the many types of aerosols that can be found mixed in the atmosphere. An important limitation of the validation is the uncertainty associated with dust observation itself. In addition, the assessments at ground stations have the added difficulty of comparing an observed value at a point with a value simulated in a relatively large grid size. A second limitation is the scarcity of observations in desert dust source regions such as northern Africa and the Middle East. Reanalysis data correspond to regions where there are very few ground based observations, and where satellite sensors have major problems to obtain accurate information due to high ground reflectivity. For this reason dust reanalysis data become unique information in this study domain.
The results highlighted in the present study will help not only the climate-weather scientific community but also enduser communities to prevent the impact of severe events over desert source regions where dust is considered to be a harmful air pollutant. Moreover, MACC-II reanalysis could be used in several health-related applications, such as epidemiological studies, or to obtain maps of solar radiation attenuation by mineral dust in suspension, or in ocean research to relate dust deposition with chlorophyll records, among others. 


\section{Appendix A: MACC-II skill scores}

The mean bias (MB), the root-mean-square errors (RMSE), the modified normalized mean bias (MNMB), also termed mean fractional bias (MFB), the fractional gross error (FGE), also known as mean fractional error (MFE) and the Pearson's correlation coefficient $(r)$ have been used to validate the performance of MACC-II outputs. These metrics, of which there is a detailed description in Huijnen and Eskes (2012) and references herein, are summarized in Table 2. MB shows the average deviations between estimated and observed values, while RMSE represents the SD of the differences between estimated values and observed values. MNMB is a measure of the estimation bias error, bounded by the values -2 to 2 (or from -200 to $200 \%$ ), which allows analyzing symmetrically how the model overestimates or underestimates respect to observed values. The FGE is a measure of overall model error and is bounded by the values 0 to 2 (0 to $200 \%$ ) and behaves symmetrically with respect to under and overestimation, without over emphasizing outliers. The Pearson's correlation coefficient is a measure of the strength and direction of the linear relationship between two variables, and indicates the degree of match between estimated and observed values.
Taylor diagrams (Taylor, 2001) provide a visual framework for comparing model results or observations to reference observations. The similarity between model/observations with reference observations is quantified in terms of their correlation, their centred root-mean-square error (CRMSE), defined in Table A1, and the amplitude of their variations (represented by their SDs). The CRMSE between the simulated and observed patterns is proportional to the distance to the point on the $x$ axis identified as "observed."

The standard skill scores and Taylor diagrams presented in this section are used in this work to evaluate the relative skill of MACC-II in comparison with satellite observations using AERONET as the reference (see Sect. 4.1.2).

Table A1. Metrics used to quantify the level of agreement between MACC-II simulations and the observations, where $n$ is the number of data used in the validation, $f_{i}$ is the estimated value by MACC-II or the observed value by satellite sensors, and $O_{i}$ is the observed reference ("true") value.

\begin{tabular}{llcc}
\hline Metrics & Equation & Range & Perfect score \\
\hline Mean bias (MB) & $=\frac{1}{n} \sum f_{i}-O_{i}$ & $-\infty$ to $+\infty$ & 0 \\
Modified normalized mean bias (MNMB) & $=\frac{2}{n} \sum \frac{f_{i}-O_{i}}{f_{i}+O_{i}}$ & -2 to 2 & 0 \\
Fractional gross error (FGE) & $=\frac{2}{n} \sum\left|\frac{f_{i}-O_{i}}{f_{i}+O_{i}}\right|$ & 0 to 2 & 0 \\
Root mean square error (RMSE) & $=\sqrt{\frac{1}{n}\left(f_{i}-O_{i}\right)^{2}}$ & 0 to $+\infty$ & 0 \\
Centred RMS error (CRMSE) & $=\sqrt{\frac{1}{n} \sum\left\lfloor\left(f_{i}-\bar{f}\right)\left(O_{i}-\bar{O}\right)\right\rfloor^{2}}$ & 0 to $+\infty$ & 0 \\
Pearson's correlation coefficient $(r)$ & $=\frac{\sum\left(f_{i}-\bar{f}\right)\left(O_{i}-\bar{O}\right)}{N \sigma_{f} \sigma_{O}}$ & -1 to 1 & 1 \\
\hline
\end{tabular}




\section{The Supplement related to this article is available online at doi:10.5194/acp-15-3991-2015-supplement.}

Acknowledgements. This work has been supported by EU-project Monitoring Atmospheric Composition and Climate (MACC-II) under the European Union Seventh Framework Programme, grant agreement number 283576. Based on a French initiative, AMMA was developed by an international scientific group and funded by a large number of agencies, especially from Africa, European Community, France, UK and USA. More information on the scientific coordination and funding is available on the AMMA International web-site: http://www.amma-international.org. The authors acknowledge B. Chatenet who managed the Sahelian Dust Transect from 2006 to 2012, J. L. Rajot who largely participated to its installation and operation, and the local site managers in Niger (A. Maman and A. Zakou, IRD, Niamey), Mali (M. Coulibaly and I. Koné, IER, Cinzana) and Senegal (A. Diallo and T. NDiaye, IRD, M'Bour) for their efforts in the maintenance of the stations and for providing high-quality data. We acknowledge the NASA mission scientists who provided the data used in this research effort. All satellite data used in this work were obtained through Giovanni web server belongs to Goddard Earth Sciences, Data and Information Services Center (GES-DISC; http://disc.sci.gsfc.nasa.gov/giovanni). The authors acknowledge AERONET (http://aeronet.gsfc.nasa.gov) and thank the PIs of the 26 AERONET stations used in this paper for their effort in establishing and maintaining the AERONET program, including the EU-ACTRIS project for contributing to calibration efforts (AERONET-Europe TNA). J. M. Baldasano and S. Basart acknowledge the Severo Ochoa (SEV-2011-00067) program of the Spanish Government and the mobility program from the Catalan Government (BE-DGR 2012).

Edited by: S. Kazadzis

\section{References}

Abbot, D. S. and Halevy, I.: Dust aerosol important for snowball earth deglaciation, J. Climate, 23, 4121-4132, 2010.

Alados-Arboledas, L., Alcantara, A., Olmo, F. J., MartinezLozano, J. A., Estelles, V., Cachorro, V., Silva, A. M., Horvath, H., Gangl, M., and Diaz, A.: Aerosol columnar properties retrieved from CIMEL radiometers during VELETA 2002, Atmos. Environ., 42, 2654-2667, 2008.

Alonso-Pérez, S., Cuevas, E., Querol, X., Viana, M., and Guerra, J.: Impact of the Saharan dust outbreaks on the ambient levels of total suspended particles (TSP) in the marine boundary layer (MBL) of the Subtropical Eastern North Atlantic Ocean, Atmos. Environ., 41, 9468-9480, 2007.

Alonso-Pérez, S., Cuevas, E., and Querol, X.: Objective identification of synoptic meteorological patterns favouring African dust intrusions into the marine boundary layer of the subtropical eastern north Atlantic region, Meteorol. Atmos. Phys., 113, 109-124, 2011.
Amiridis, V., Wandinger, U., Marinou, E., Giannakaki, E., Tsekeri, A., Basart, S., Kazadzis, S., Gkikas, A., Taylor, M., Baldasano, J., and Ansmann, A.: Optimizing CALIPSO Saharan dust retrievals, Atmos. Chem. Phys., 13, 12089-12106, doi:10.5194/acp-1312089-2013, 2013.

Andreae, T. W., Andreae, M. O., Ichoku, C., Maenhaut, W., Cafmeyer, J., Karnieli, A., and Orlovsky, L.: Light scattering by dust and anthropogenic aerosol at a remote site in the Negev desert, Israel, J. Geophys. Res., 107, 4008, doi:10.1029/2001JD900252, 2002.

Andrey, J., Cuevas, E., Parrondo, M. C., Alonso-Pérez, S., Redondas, A., and Gil-Ojeda, M.,: Quantification of ozone reductions within the Saharan air layer through a 13-year climatologic analysis of ozone profiles, Atmos. Environ., 84, 28-34, 2014.

Banks, J. R., Brindley, H. E., Flamant, C., Garay, M. J., Hsu, N. C., Kalashnikova, O. V., Klüser, L., and Sayer, A. M.: Intercomparison of satellite dust retrieval products over the west African Sahara during the Fennec campaign in Jun 2011, Remote Sens. Environ., 136, 99-116, 2013.

Basart, S., Pérez, C., Cuevas, E., Baldasano, J. M., and Gobbi, G. P.: Aerosol characterization in Northern Africa, Northeastern Atlantic, Mediterranean Basin and Middle East from direct-sun AERONET observations, Atmos. Chem. Phys., 9, 8265-8282, doi:10.5194/acp-9-8265-2009, 2009.

Basart, S., Pérez, C., Nickovic, S., Cuevas, E., and Baldasano, J.: Development and evaluation of the BSCDREAM8b dust regional model over Northern Africa, the Mediterranean and the Middle East, Tellus B, 64, 18539, doi:10.3402/tellusb.v64i0.18539, 2012.

Bellouin, N., Quaas, J., Morcrette, J.-J., and Boucher, O.: Estimates of aerosol radiative forcing from the MACC re-analysis, Atmos. Chem. Phys., 13, 2045-2062, doi:10.5194/acp-13-20452013, 2013.

Benedetti, A. and Fisher, M.: Background error statistics for aerosols, Q. J. Roy. Meteorol. Soc., 133, 391-405, 2007.

Benedetti, A., Morcrette, J.-J., Boucher, O., Dethof, A., Engelen, R. J., Fisher, M., Flentjes, H., Huneeus, N., Jones, L., Kaiser, J. W., Kinne, S., Mangold, A., Razinger, M., Simmons, A. J., Suttie, M., and the GEMS-AER team: Aerosol analysis and forecast in the ECMWF Integrated Forecast System. Part II: Data assimilation, J. Geophys. Res., 114, D13205, doi:10.1029/2008JD011115, 2009.

Boucher, O., Pham, M., and Venkataraman, C.: Simulation of the Atmospheric Sulfur Cycle in the LMD GCM: Model Description, Model Evaluation, and Global and European Budgets, Inst. Pierre-Simon Laplace, Paris, France, Note 23, 26 pp., available at: www.ipsl.jussieu.fr/poles/Modelisation/NotesSciences. htm (last access: 22 October 2014), 2002.

Boylan, J. W. and Russel, A. G.: PM and light extinction model performance metrics, goals, and criteria for three-dimensional air quality models, Atmos. Environ., 40, 4946-4959, 2006.

Burton, S. P., Ferrare, R. A., Vaughan, M. A., Omar, A. H., Rogers, R. R., Hostetler, C. A., and Hair, J. W.: Aerosol classification from airborne HSRL and comparisons with the CALIPSO vertical feature mask, Atmos. Meas. Tech., 6, 13971412, doi:10.5194/amt-6-1397-2013, 2013.

Campbell, J. R., Hlavka, D. L., Welton, E. J., Flynn, C. J., Turner, D. D., Spinhirne, J. D., Scott, V. S., and Hwang, I. H.: Full-time, eye-safe cloud and aerosol lidar observation at at- 
mospheric radiation measurement program sites: instrument and data processing, J. Atmos. Ocean. Tech., 19, 431-442, 2002.

Capes, G., Johnson, B., McFiggans, G., Williams, P. I., Haywood, J., and Coe, H.: Aging of biomass burning aerosols over West Africa: aircraft measurements of chemical composition, microphysical properties and emission ratios, J. Geophys. Res., 113, D00C15, doi:10.1029/2008JD009845, 2008.

Cavalieri, O., Cairo, F., Fierli, F., Di Donfrancesco, G., Snels, M., Viterbini, M., Cardillo, F., Chatenet, B., Formenti, P., Marticorena, B., and Rajot, J. L.: Variability of aerosol vertical distribution in the Sahel, Atmos. Chem. Phys., 10, 12005-12023, doi:10.5194/acp-10-12005-2010, 2010.

Cesnulyte, V., Lindfors, A. V., Pitkänen, M. R. A., Lehtinen, K. E. J., Morcrette, J.-J., and Arola, A.: Comparing ECMWF AOD with AERONET observations at visible and UV wavelengths, Atmos. Chem. Phys., 14, 593-608, doi:10.5194/acp-14593-2014, 2014.

Cuevas, E., González, Y., Rodríguez, S., Guerra, J. C., GómezPeláez, A. J., Alonso-Pérez, S., Bustos, J., and Milford, C.: Assessment of atmospheric processes driving ozone variations in the subtropical North Atlantic free troposphere, Atmos. Chem. Phys., 13, 1973-1998, doi:10.5194/acp-13-1973-2013, 2013.

Cziczo, D. J., Froyd, K. D., Hoose, C., Jensen, E. J., Diao, M., Zondlo, M. A., Smith, J. B., Twohy, C. H., and Murphy, D. M.: Clarifying the dominant sources and mechanisms of cirrus cloud formation, Science, 340, 1320-1324, doi:10.1126/science.1234145, 2013.

Dee, D. P. and Uppala, S.: Variational bias correction of satellite radiance data in the ERA-Interim reanalysis, Q. J. R. Meteorol. Soc., 135, 1830-1841, 2009.

Dentener, F., Kinne, S., Bond, T., Boucher, O., Cofala, J., Generoso, S., Ginoux, P., Gong, S., Hoelzemann, J. J., Ito, A., Marelli, L., Penner, J. E., Putaud, J.-P., Textor, C., Schulz, M., van der Werf, G. R., and Wilson, J.: Emissions of primary aerosol and precursor gases in the years 2000 and 1750 prescribed data-sets for AeroCom, Atmos. Chem. Phys., 6, 4321-4344, doi:10.5194/acp-64321-2006, 2006.

Derimian, Y., Karnieli, A., Kaufman, Y. J., Andreae, M. O., Andreae, T. W., Dubovik, O., Maenhaut, W., Koren, I., and Holben, B. N.: Dust and pollution aerosols over the Negev desert, Israel: properties, transport, and radiative effect, J. Geophys. Res., 111, D05205, doi:10.1029/2005JD006549, 2006.

Diner, D. J., Beckert, J. C., Reilly, T. H., Bruegge, C. J., Conel, J. E., Kahn, R. A., Martonchik, R. A., Ackerman, T. P., Davies, R., Gerstl, S., Gordon, H. R., Muller, J.-P., Myneni, R., Sellers, P., Pinty, B., and Verstraete, M.: Multi-angle Imaging Spectro Radiometer (MISR) instrument description and experiment overview, IEEE T. Geosci. Remote, 36, 1072-1087, 1998.

Diner, D. J., Abdou, W. A., Bruegge, C. J., Conel, J. E., Crean, K. A., Gaitley, B. J., Helmlinger, M. C., Kahn, R. A., Martonchik, J. V., Pilorz, S. H., and Holben, B. N.: MISR aerosol optical depth retrievals over southern Africa during the SAFARI2000 dry season campaign, Geophys. Res. Lett., 28, 3127-3130, 2001.

Diner, D. J., Abdou, W., Ackerman, T., Crean, K., Gordon, H., Kahn, R., Martonchik, J., McMuldroch, S., Paradise, S., Pinty, B., Verstrete, M., Wang, M., and West, R.: MISR Level 2 Aerosol Retrieval Algorithm Theoretical Basis, JPL, D11400, available at: http://eospso.gsfc.nasa.gov/sites/default/files/atbd/ atbd-misr-09.pdf (last access: 4 November 2014), 2008.

Doherty, S. J., Anderson, T. L., and Charlson, R. J.: Measurement of the lidar ratio for atmospheric aerosols with a $180^{\circ}$ backscatter nephelometer, Appl. Optics, 38, 1823-1832, 1999.

Dubovik, O., Holben, B. N., Eck, T. F., Smirnov, A., Kaufman, Y. J., King, M. D., Tanre, D., and Slutsker, I.: Variability of absorption and optical properties of key aerosol types observed in worldwide locations, J. Atmos. Sci., 59, 590-608, 2002.

Eck, T. F., Holben, B. N., Reid, J. S., Dubovik, O., Smirnov, A., O'Neill, N. T., Slutsker, I., and Kinne, S.: Wavelength dependence of the optical depth of biomass burning, urban, and desert dust aerosols, J. Geophys. Res., 104, 31333-31349, 1999.

Eck, T. F., Holben, B. N., Reid, J. S., Sinyuk, A., Dubovik, O., Smirnov, A., Giles, D., O’Neill, N. T., Tsay, S.-C., Ji, Q., Al Mandoos, A., Ramzan Khan, M., Reid, E. A., Schafer, J. S., Sorokine, M., Newcomb, W., and Slutsker, I.: Spatial and temporal variability of column-integrated aerosol optical properties in the southern Arabian Gulf and United Arab Emirates in summer, J. Geophys. Res., 113, 2156-2202, doi:10.1029/2007JD008944, 2008.

Elguindi, N., Clark, H., Ordóñez, C., Thouret, V., Flemming, J., Stein, O., Huijnen, V., Moinat, P., Inness, A., Peuch, V.-H., Stohl, A., Turquety, S., Athier, G., Cammas, J.-P., and Schultz, M.: Current status of the ability of the GEMS/MACC models to reproduce the tropospheric $\mathrm{CO}$ vertical distribution as measured by MOZAIC, Geosci. Model Dev., 3, 501-518, doi:10.5194/gmd-3501-2010, 2010.

Engelstaedter, S., Tegen, I., and Washington, R.: North African dust emissions and transport, Earth-Sci. Rev., 79, 73-100, 2006.

Giannadaki, D., Pozzer, A., and Lelieveld, J.: Modeled global effects of airborne desert dust on air quality and premature mortality, Atmos. Chem. Phys., 14, 957-968, doi:10.5194/acp-14-9572014, 2014.

Gillies, J. A., Nickling, W. G., and Mctainsh, G. H.: Dust concentrations and particle-size characteristics of an intense dust haze event: inland Delta Region, Mali, West Africa, Atmos. Environ., 30, 1081-1090, 1996.

Ginoux, P. and Torres, O.: Empirical TOMS index for dust aerosol: application to model validation and source characterization, J. Geophys. Res., 108, 4534, doi:10.1029/2003JD003470, 2003.

Ginoux, P., Prospero, J. M., Torres, O., and Chin, M.: Long-term simulation of global dust distribution with the GOCART model: correlation with North Atlantic Oscillation, Environ. Modell. Softw., 19, 113-128, 2004.

Groß, S., Gasteiger, J., Freudenthaler, V., Wiegner, M., Geiß, A., Schladitz, A., Toledano, C., Kandler, K., Tesche, M., Ansmann, A., and Wiedensohler, A.: Characterization of the planetary boundary layer during SAMUM-2 by means of lidar measurements, Tellus B, 63, 695-705, doi:10.1111/j.16000889.2011.00557.X, 2011.

Guelle, W., Schulz, M., Balkanski, Y., and Dentener, F.: Influence of the source formulation on modeling the atmospheric global distribution of the sea salt aerosol, J. Geophys. Res., 106, 27509 27524, 2001.

Guirado, C., Cuevas, E., Cachorro, V. E., Toledano, C., AlonsoPérez, S., Bustos, J. J., Basart, S., Romero, P. M., Camino, C., Mimouni, M., Zeudmi, L., Goloub, P., Baldasano, J. M., and de Frutos, A. M.: Aerosol characterization at the Saharan 
AERONET site Tamanrasset, Atmos. Chem. Phys., 14, 1175311773, doi:10.5194/acp-14-11753-2014, 2014.

Hamza, W., Rizk Enan, M., Al-Hassini, H., Jan-Berend, S., and deBeer, D.: Dust storms over the Arabian Gulf: a possible indicator of climate changes consequences, Aquat. Ecosyst. Health, 14, 260-268, 2011.

Hansen, J., Sato, M., and Ruedy, R.: Radiative forcing and climate response, J. Geophys. Res., 102, 6831-6864, 1997.

Hauglustaine, D. A., Hourdin, F., Jourdain, L., Filiberti, M. A., Walters, S., Lamarque, J. F., and Holland, E. A.: Interactive chemistry in the Laboratoire de Meteorologie Dynamique general circulation model: description and background tropospheric chemistry evaluation, J. Geophys. Res., 109, D04314, doi:10.1029/2003JD003957, 2004.

Haustein, K., Pérez, C., Baldasano, J. M., Jorba, O., Basart, S., Miller, R. L., Janjic, Z., Black, T., Nickovic, S., Todd, M. C., Washington, R., Müller, D., Tesche, M., Weinzierl, B., Esselborn, M., and Schladitz, A.: Atmospheric dust modeling from meso to global scales with the online NMMB/BSC-Dust model - Part 2: Experimental campaigns in Northern Africa, Atmos. Chem. Phys., 12, 2933-2958, doi:10.5194/acp-12-2933-2012, 2012.

Haywood, J. M., Pelon, J., Formenti, P., Bharmal, N., Brooks, M., Capes, G., Chazette, P., Chou, C., Christopher, S., Coe, H., Cuesta, J., Derimian, Y., Desboeufs, K., Greed, G., Harrison, M., Heese, B., Highwood, E. J., Johnson, B., Mallet, M., Marticorena, B., Marsham, J., Milton, S., Myhre, G., Osborne, S. R., Parker, D. J., Rajot, J.-L., Schulz, M., Slingo, A., Tanré, D., and Tulet, P.: Overview of the dust and biomass burning experiment and African monsoon multidisciplinary analysis special observing period-0, J. Geophys. Res., 113, D00C11, doi:10.1029/2008JD010077, 2008.

Heymsfield, A. J., Bansemer, A., Heymsfield, G., and Fierro, A. O.: Microphysics of maritime tropical convective updrafts at temperatures from $-20^{\circ}$ to $-60^{\circ}$, J. Atmos. Sci., 66, 3530-3562, 2009.

Holben, B. N., Eck, T. F., Slutsker, I., Tanré, D., Buis, J. P., Setzer, A., Vermote, E., Reagan, J., Kaufman, Y., Nakajima, T., Lavenu, F., Jankowiak, I., and Smirnov, A.: AERONET: a federated instrument network and data archive for aerosol characterization, Remote Sens. Environ., 66, 1-16, 1998.

Hoose, C. and Möhler, O.: Heterogeneous ice nucleation on atmospheric aerosols: a review of results from laboratory experiments, Atmos. Chem. Phys., 12, 9817-9854, doi:10.5194/acp-12-98172012, 2012.

Hsu, N. C., Tsay, S. C., King, M. D., and Herman, J. R.: Aerosol properties over bright-reflecting source regions, IEEE T. Geosci. Remote, 42, 557-569, 2004.

Hsu, N. C., Tsay, S., King, M. D., and Herman, J. R.: Deep blue retrievals of asian aerosol properties during ACE-Asia, IEEE T. Geosci. Remote, 44, 3180-3195, 2006.

Huijnen, V. and Eskes, H.: Skill Scores and Evaluation Methodology for The MACC II Project, MACC-II Deliverable D_85.2, available at: https://www.gmes-atmosphere.eu/ documents/maccii/deliverables/val/MACCII_VAL_DEL_

D_85.2_ScoringReport01_20120222.pdfKNMI (last access: 4 November 2014), De Bilt, the Netherlands, 2012.

Huneeus, N., Schulz, M., Balkanski, Y., Griesfeller, J., Prospero, J., Kinne, S., Bauer, S., Boucher, O., Chin, M., Dentener, F., Diehl, T., Easter, R., Fillmore, D., Ghan, S., Ginoux, P., Grini, A., Horowitz, L., Koch, D., Krol, M. C., Landing, W., Liu, X.,
Mahowald, N., Miller, R., Morcrette, J.-J., Myhre, G., Penner, J., Perlwitz, J., Stier, P., Takemura, T., and Zender, C. S.: Global dust model intercomparison in AeroCom phase I, Atmos. Chem. Phys., 11, 7781-7816, doi:10.5194/acp-11-7781-2011, 2011.

Inness, A., Baier, F., Benedetti, A., Bouarar, I., Chabrillat, S., Clark, H., Clerbaux, C., Coheur, P., Engelen, R. J., Errera, Q., Flemming, J., George, M., Granier, C., Hadji-Lazaro, J., Huijnen, V., Hurtmans, D., Jones, L., Kaiser, J. W., Kapsomenakis, J., Lefever, K., Leitão, J., Razinger, M., Richter, A., Schultz, M. G., Simmons, A. J., Suttie, M., Stein, O., Thépaut, J.-N., Thouret, V., Vrekoussis, M., Zerefos, C., and the MACC team: The MACC reanalysis: an 8 yr data set of atmospheric composition, Atmos. Chem. Phys., 13, 4073-4109, doi:10.5194/acp-13-4073-2013, 2013.

IPCC: Climate Change 2013: The Physical Science Basis. Contribution of Working Group I to the Fifth Assessment Report of the Intergovernmental Panel on Climate Change, edited by: Stocker, T. F., Qin, D., Plattner, G.-K., Tignor, M., Allen, S. K., Boschung, J., Nauels, A., Xia, Y., Bex, V., and Midgley, P. M., Cambridge University Press, Cambridge, UK and New York, NY, USA, 1535 p., 2013.

Israelevich, P.: Effect of Terrain Relief on the Transport of Dust Aerosol, DUST2014 - 1st International Conference on Atmospheric Dust, MF2-P, Castellaneta Marina, Italy, 1-6 June 2014, 2014.

Jansen, E., Overpeck, J., Briffa, K. R., Duplessy, J.-C., Joos, F., Masson-Delmotte, V., Olago, D., Otto-Bliesner, B., Peltier, W. R., Rahmstorf, S., Ramesh, R., Raynaud, D., Rind, D., Solomina, O., Villalba, R., and Zhang, D.: Palaeoclimate, in: Climate Change 2007: The Physical Science Basis. Contribution of Working Group I to the Fourth Assessment Report of the Intergovernmental Panel on Climate Change, edited by: Solomon, S., Qin, D., Manning, M., Chen, Z., Marquis, M., Averyt, K. B., Tignor, M., and Miller, H. L., Cambridge University Press, Cambridge, UK and New York, NY, USA, 433-497, 2007.

Jickells, T. D., An, Z. S., Andersen, K. K., Baker, A. R., Bergametti, G., Brooks, N., Cao, J. J., Boyd, P. W., Duce, R. A., Hunter, K. A., Kawahata, H., Kubilay, N., la Roche, J. S. L. P., Mahowald, N., Prospero, J. M., Ridgwell, A. J., Tegen, I., and Torres, R.: Global iron connections between desert dust, ocean biogeochemistry, and climate, Science, 308, 67-71, 2005.

Kahn, R. A., Gaitley, B. J., Martonchik, J. V., Diner, D. J., Crean, K. A., and Holben, B. N.: Multiangle Imaging Spectroradiometer (MISR) global aerosol optical depth validation based on 2 years of coincident Aerosol Robotic Network (AERONET) observations, J. Geophys. Res., 110, D10S04, doi:10.1029/2004JD004706, 2005.

Kahn, R. A., Gaitley, B. J., Garay, M. J., Diner, D. J., Eck, T. F., Smirnov, A., and Holben, B. N.: Multiangle Imaging SpectroRadiometer global aerosol product assessment by comparison with the Aerosol Robotic Network, J. Geophys. Res., 115, D23209, doi:10.1029/2010JD014601, 2010.

Kaiser, J. W., Heil, A., Andreae, M. O., Benedetti, A., Chubarova, N., Jones, L., Morcrette, J.-J., Razinger, M., Schultz, M. G., Suttie, M., and van der Werf, G. R.: Biomass burning emissions estimated with a global fire assimilation system based on observed fire radiative power, Biogeosciences, 9, 527-554, doi:10.5194/bg-9-527-2012, 2012. 
Karyampudi, V., Palm, S., Reagen, J., Fang, H., Grant, W., Hoff, R., Moulin, C., Pierce, H., Torres, O., Browell, E., and Melfi, S.: Validation of the saharan dust plume conceptual model using lidar, Meteosat, and ECMWF data, B. Am. Meteorol. Soc., 80, 10451075, 1999.

Kaskaoutis, D. G., Kambezidis, H. D., Adamopoulos, A. D., and Kassomenos, P. A.: Comparison between experimental data and modeling estimates of atmospheric optical depth over Athens, Greece, J. Atmos. Sol.-Terr. Phy., 68, 1167-1178, 2006.

Kaskaoutis, D. G., Kambezidis, H. D., Hatzianastassiou, N., Kosmopoulos, P. G., and Badarinath, K. V. S.: Aerosol climatology: dependence of the Angstrom exponent on wavelength over four AERONET sites, Atmos. Chem. Phys. Discuss., 7, 7347-7397, doi:10.5194/acpd-7-7347-2007, 2007.

Kaufman, Y. J., Tanré, D., Remer, L. A., Vermote, E. F., Chu, A., and Holben, B. N.: Operational remote sensing of tropospheric aerosol over land from EOS moderate resolution imaging spectroradiometer, J. Geophys. Res., 102, 17-51, 1997.

Kim, S. W., Yoon, S. C., Kim, J., and Kim, S. Y.: Seasonal and monthly variations of columnar aerosol optical properties over east Asia determined from multi-year MODIS, LIDAR, and AERONET Sun/sky radiometer measurements, Atmos. Environ., 41, 1634-1651, 2007.

Kinne, S., Schulz, M., Textor, C., Guibert, S., Balkanski, Y., Bauer, S. E., Berntsen, T., Berglen, T. F., Boucher, O., Chin, M., Collins, W., Dentener, F., Diehl, T., Easter, R., Feichter, J., Fillmore, D., Ghan, S., Ginoux, P., Gong, S., Grini, A., Hendricks, J., Herzog, M., Horowitz, L., Isaksen, I., Iversen, T., Kirkevåg, A., Kloster, S., Koch, D., Kristjansson, J. E., Krol, M., Lauer, A., Lamarque, J. F., Lesins, G., Liu, X., Lohmann, U., Montanaro, V., Myhre, G., Penner, J., Pitari, G., Reddy, S., Seland, O., Stier, P., Takemura, T., and Tie, X.: An AeroCom initial assessment - optical properties in aerosol component modules of global models, Atmos. Chem. Phys., 6, 1815-1834, doi:10.5194/acp-6-1815-2006, 2006.

Klein, H., Nickovic, S., Haunold, W., Bundke, U., Nillius, B., Ebert, M., Weinbruch, S., Schuetz, L., Levin, Z., Barrie, L. A., and Bingemer, H.: Saharan dust and ice nuclei over Central Europe, Atmos. Chem. Phys., 10, 10211-10221, doi:10.5194/acp10-10211-2010, 2010.

Klett, J. D.: Stable analytic inversion solution for processing lidar returns, Appl. Optics, 20, 211-220, 1981.

Klett, J. D.: Lidar inversion with variable backscatter/extinction ratios, Appl. Optics, 24, 1638-1643, 1985.

Knippertz, P. and Todd, M. C.: Mineral dust aerosols over the Sahara: Meteorological controls on emission and transport and implications for modeling, Rev. Geophys., 50, RG1007, doi:10.1029/2011RG000362, 2012.

Knippertz, P., Ansmann, A., Althausen, D., Müller, D., Tesche, M., Bierwirth, E., Dinter, T., Müller, T., von Hoyningen-Huene, W., Schepanski, K., Wendisch, M., Heinold, B., Kandler, K., Petzold, A., Schütz, L., and Tegen, I.: Dust mobilization and transport in the Northern Sahara during SAMUM 2006 - a meteorological overview, Tellus B, 61, 12-31, doi:10.1111/j.16000889.2008.00380.x, 2009.

Kubilay, N., Cokacar, T., and Oguz, T.: Optical properties of mineral dust outbreaks over the northeastern Mediterranean, J. Geophys. Res., 108, 4666, doi:10.1029/2003JD003798, 2003.
Kunz, G. and de Leeuw, G.: Inversion of lidar signals with the slope method, Appl. Optics, 32, 3249-3256, 1993.

Léon, J.-F., Derimian, Y., Chiapello, I., Tanré, D., Podvin, T., Chatenet, B., Diallo, A., and Deroo, C.: Aerosol vertical distribution and optical properties over M'Bour $\left(16.96^{\circ} \mathrm{W} ; 14.39^{\circ} \mathrm{N}\right)$, Senegal from 2006 to 2008, Atmos. Chem. Phys., 9, 9249-9261, doi:10.5194/acp-9-9249-2009, 2009.

Levelt, P. F., Hilsenrath, E., Leppelmeier, G. W., van den Ooord, G. H. J., Bhartia, P. K., Taminnen, J., de Haan, J. F., and Veefkind, J. P.: Science objectives of the Ozone Monitoring Instrument, IEEE Trans. Geosci. Remote, 44, 1093-1101, 2006.

Liousse, C., Guillaume, B., Grégoire, J. M., Mallet, M., Galy, C., Pont, V., Akpo, A., Bedou, M., Castéra, P., Dungall, L., Gardrat, E., Granier, C., Konaré, A., Malavelle, F., Mariscal, A., Mieville, A., Rosset, R., Serça, D., Solmon, F., Tummon, F., Assamoi, E., Yoboué, V., and Van Velthoven, P.: Updated African biomass burning emission inventories in the framework of the AMMAIDAF program, with an evaluation of combustion aerosols, Atmos. Chem. Phys., 10, 9631-9646, doi:10.5194/acp-10-96312010, 2010.

Liu, M., Westphal, D. L., Holt, T. R., and Xu, Q.: Numerical simulation of a low-level jet over complex terrain in Southern Iran, Mon. Weather Rev., 128, 1309-1327, 2000.

Liu, Z., Winker, D., Omar, A., Vaughan, M., Trepte, C., Hub, Y., Powell, K., Sun, W., and Lin, B.: Effective lidar ratios of dense dust layers over North Africa derived from the CALIOP measurements, J. Quant. Spectrosc. Ra., 112, 204-213, doi:10.1016/j.jqsrt.2010.05.006,2010.

Lyamani, H., Olmo, F. J., and Alados-Arboledas, L.: Physical and optical properties of aerosols over an urban location in Spain: seasonal and diurnal variability, Atmos. Chem. Phys., 10, 239254, doi:10.5194/acp-10-239-2010, 2010.

Mahowald, N. M., Baker, A. R., Bergametti, G., Brooks, N., Duce, R. A., Jickells, T. D., Kubilay, N., Prospero, J. M., and Tegen, I.: The atmospheric global dust cycle and iron inputs to the ocean, Global Biogeochem. Cy., 19, GB4025, doi:10.1029/2004GB002402, 2005.

Mahowald, N. M., Kloster, S., Engelstaedter, S., Moore, J. K., Mukhopadhyay, S., McConnell, J. R., Albani, S., Doney, S. C., Bhattacharya, A., Curran, M. A. J., Flanner, M. G., Hoffman, F. M., Lawrence, D. M., Lindsay, K., Mayewski, P. A., Neff, J., Rothenberg, D., Thomas, E., Thornton, P. E., and Zender, C. S.: Observed 20th century desert dust variability: impact on climate and biogeochemistry, Atmos. Chem. Phys., 10, 10875-10893, doi:10.5194/acp-10-10875-2010, 2010.

Marticorena, B., Chatenet, B., Rajot, J. L., Traoré, S., Coulibaly, M., Diallo, A., Koné, I., Maman, A., NDiaye, T., and Zakou, A.: Temporal variability of mineral dust concentrations over West Africa: analyses of a pluriannual monitoring from the AMMA Sahelian Dust Transect, Atmos. Chem. Phys., 10, 8899-8915, doi:10.5194/acp-10-8899-2010, 2010.

Marticorena, B., Haywood, J., Coe, H., Formenti, P., Liousse, C., Mallet, M., and Pelon, J.: Tropospheric aerosols over West Africa: highlights from the AMMA international program, Atmos. Sci. Lett., 12, 19-23, doi:10.1002/asl.322, 2011.

Menut, L.: Sensitivity of hourly Saharan dust emissions to NCEP and ECMWF modeled wind speed, J. Geophys. Res., 113, D16201, doi:10.1029/2007JD009522, 2008. 
Middleton, N. J.: Dust storms in the Middle East, J. Arid Environ., 10, 83-96, 1986.

Middleton, N. J. and Goudie, A. S.: Saharan dust: sources and trajectories, T. I. Brit. Geogr., 26, 165-181, doi:10.1111/14755661.00013, 2001.

Monahan, E. C., Spiel, D. E., and Davidson, K. L.: A model of marine aerosol generation via whitecaps and wave disruption, in: Oceanic Whitecaps, edited by: Monahan, E. C. and MacNiocaill, G., D. Reidel, Norwell, Mass., 167-174, 1986.

Morcrette, J.-J., Beljaars, A., Benedetti, A., Jones, L., and Boucher, O.: Sea-salt and dust aerosols in the ECMWF IFS model, Geophys. Res. Lett., 35, L24813, doi:10.1029/2008GL036041, 2008.

Morcrette, J.-J., Boucher, O., Jones, L., Salmond, D., Bechtold, P., Beljaars, A., Benedetti, A., Bonet, A., Kaiser, J. W., Razinger, M., Schulz, M., Serrar, S., Simmons, A. J., Sofiev, M., Suttie, M., Tompkins, A. M., and Untch, A.: Aerosol analysis and forecast in the ECMWF integrated forecast system. Part I: Forward modelling, J. Geophys. Res., 114, D06206, doi:10.1029/2008JD011235, 2009.

Morcrette, J.-J., Benedetti, A., Jones, L., Kaiser, J. W., Razinger, M., and Suttie, M.: Prognostic Aerosols in the ECMWF IFS: MACC vs. GEMS Aerosols, ECMWF Tech Memo 659, available at: http://old.ecmwf.int/publications/library/ecpublications/_pdf/ tm/601-700/tm659.pdf (last access: 4 November 2014), 2011.

Mortier, A.: Tendances et variabilités de l'aérosol atmosphérique à l'aide du couplage Lidar/Photomètre sur les sites de Lille et Dakar, Ph.D. thesis, Laboratoire d'Optique Atmosphérique, UFR de Physique, Université Lille 1, Sciences et Technologies, University of Lille, Villeneuve d'Ascq, France, 2013.

Moulin, C. and Chiapello, I.: Evidence of the control of summer atmospheric transport of African dust over the Atlantic by Sahel sources from TOMS satellites (1979-2000), Geophys. Res. Lett., 31, L02107, doi:10.1029/2003GL018931, 2004.

Moulin, C., Lambert, C. E., Dulac, F., and Dayan, U.: Control of atmospheric export of dust from North Africa by the North Atlantic Oscillation, Nature, 387, 691-694, doi:10.1038/42679, 1997.

Nickovic, S., Kallos, G., Papadopoulos, A., and Kakaliagou, O.: A model for prediction of desert dust cycle in the atmosphere, J. Geophys. Res., 106, 18113-18130, doi:10.1029/2000JD900794, 2001.

Nickovic, S., Vukovic, A., and Vujadinovic, M.: Atmospheric processing of iron carried by mineral dust, Atmos. Chem. Phys., 13, 9169-9181, doi:10.5194/acp-13-9169-2013, 2013.

Okin, G. S., Mahowald, N., Chadwick, O. A., and Artaxo, P.: Impact of desert dust on the biogeochemistry of phosphorus in terrestrial ecosystems, Global Biogeochem. Cy., 18, GB2005, doi:10.1029/2003GB002145, 2004.

Omar, A., Liu, Z., Vaughan, M., Thornhill, K., Kittaka, C., Ismail, S., Hu, Y., Chen, G., Powell, K., Winker, D., Trepte, C., Winstead, E., and Anderson, B.: Extinction-to-backscatter ratios of Saharan dust layers derived from in situ measurements and CALIPSO overflights during NAMMA, J. Geophys. Res., 115, D24217, doi:10.1029/2010JD014223, 2010.

O’Neill, N. T., Eck, T. F., Holben, B. N., Smirnov, A., Dubovik, O., and Royer, A.: Bi-modal size distribution influences on the variation of Angstrom derivatives in spectral and optical depth space, J. Geophys. Res., 106, 9787-9806, 2001.
O’Neill, N. T., Eck, T. F., Smirnov, A., Holben, B. N., and Thulasiraman, S.: Spectral discrimination of coarse and fine mode optical depth, J. Geophys. Res., 108, 4559-4573, doi:10.1029/2002JD002975, 2003.

Parrish, D. F. and Derber, J. C.: The National Meteorological Center's spectral statistical-interpolation analysis system, Mon. Weather Rev., 120, 1747-1763, 1992.

Pedrós, R., Martinez-Lozano, J. A., Utrillas, M. P., GómezAmo, J. L., and Tena, F.: Column integrated aerosol, optical properties from ground-based spectroradiometer measurements at Barrax (Spain) during the Digital Airborne Imaging Spectrometer Experiment (DAISEX) campaigns, J. Geophys. Res., 108, 4571, doi:10.1029/2002JD003331, 2003.

Pelon, J., Mallet, M., Mariscal, A., Goloub, P., Tanré, D., Karam, D. B., Flamant, C., Haywood, J., Pospichal, B., and Victori, S.: Microlidar observations of biomass burning aerosol over Djougou (Benin) during African Monsoon multidisciplinary analysis special observation period 0: dust and biomass-burning experiment, J. Geophys. Res., 113, D00C18, doi:10.1029/2008JD009976, 2008.

Pérez, C., Nickovic, S., Baldasano, J. M., Sicard, M., Rocadenbosch, F., and Cachorro, V. E.: A long Saharan dust event over the western Mediterranean: lidar, Sun photometer observations, and regional dust modeling, J. Geophys. Res., 111, D15214, doi:10.1029/2005JD006579, 2006a.

Pérez, C., Nickovic, S., Pejanovic, G., Baldasano, J. M., and Ozsoy, E.: Interactive dust-radiation modeling: a step to improve weather forecasts, J. Geophys. Res., 111, D16206, doi:10.1029/2005JD006717, 2006b.

Pérez, C., Haustein, K., Janjic, Z., Jorba, O., Huneeus, N., Baldasano, J. M., Black, T., Basart, S., Nickovic, S., Miller, R. L., Perlwitz, J. P., Schulz, M., and Thomson, M.: Atmospheric dust modeling from meso to global scales with the online NMMB/BSC-Dust model - Part 1: Model description, annual simulations and evaluation, Atmos. Chem. Phys., 11, 1300113027, doi:10.5194/acp-11-13001-2011, 2011.

Pérez García-Pando, C., Stanton, M. C., Diggle, P. J., Trzaska, S., Miller, R. L., Perlwitz, J. P., Baldasano, J. M., Cuevas, E., Ceccato, P., Yaka, P., and Thomson, M. C.: Soil dust aerosols and wind as predictors of seasonal meningitis incidence in Niger, Environ. Health Persp., 122, 679-686, doi:10.1289/ehp.1306640, 2014.

Prospero, J. M. and Carlson, T. N.: Saharan air outbreaks over the tropical North Atlantic, Pure Appl. Geophys., 119, 677-691, 1981.

Prospero, J. M. and Nees, R. T.: Impact of the North African drought and El Niño on mineral dust in the Barbados trade winds, Nature, 320, 735-738, doi:10.1038/320735a0, 1986.

Prospero, J. M., Schmitt, R., Cuevas, E., Savoie, D. L., Graustein, W. C., Turekian, K. K., Volz-Thomas, A., DmHaz, A., Oltmans, S. J., and Levy II, H.: Temporal variability of summertime ozone and aerosols in the free troposphere over the eastern North Atlantic, Geophys. Res. Lett., 22, 2925-2928, 1995.

Reddy, M. S., Boucher, O., Bellouin, N., Schulz, M., Balkanski, Y., Dufresne, J.-L., and Pham, M.: Estimates of global multi-component aerosol optical depth and direct radiative perturbation in the Laboratoire de Météorologie Dynamique general circulation model, J. Geophys. Res., 110, D10S16, doi:10.1029/2004JD004757, 2005. 
Remer, L. A., Kaufman, Y. J., Tanr'e, D., Mattoo, S., Chu, D. A., Martins, J. V., Li, R. R., Ichoku, C., Levy, R. C., Kleidman, R. G., Eck, T. F., Vermote, E., and Holben, B. N.: The MODIS aerosol algorithm, products, and validation, J. Atmos. Sci., 62, 947-973, 2005.

Rezazadeh, M., Irannejad, P., and Shao, Y.: Climatology of the Middle East dust events, Aeolian Res., 10, 103-109, 2013.

Rodríguez, S., Alastuey, A., Alonso-Pérez, S., Querol, X., Cuevas, E., Abreu-Afonso, J., Viana, M., Pérez, N., Pandolfi, M., and de la Rosa, J.: Transport of desert dust mixed with North African industrial pollutants in the subtropical Saharan Air Layer, Atmos. Chem. Phys., 11, 6663-6685, doi:10.5194/acp-11-66632011, 2011.

Rodríguez, S., Cuevas, E., Prospero, J. M., Alastuey, A., Querol, X., López-Solano, J., García, M. I., and Alonso-Pérez, S.: Modulation of Saharan dust export by the North African dipole, Atmos. Chem. Phys. Discuss., 14, 26689-26719, doi:10.5194/acpd-1426689-2014, 2014

Salomonson, V. V., Barnes, W. L., Maymon, P. W., Montgomery, H. E., and Ostrow, H.: MODIS: advanced facility instrument forstudies of the Earth as a system, IEEE T. Geosci. Remote, 27, 145-153, 1989.

Schepanski, K., Tegen, I., and Macke, A.: Comparison of satellite based observations of Saharan dust source areas, Remote Sens. Environ., 123, 90-97, 2012.

Schmechtig, C., Marticorena, B., Chatenet, B., Bergametti, G., Rajot, J. L., and Coman, A.: Simulation of the mineral dust content over Western Africa from the event to the annual scale with the CHIMERE-DUST model, Atmos. Chem. Phys., 11, 7185-7207, doi:10.5194/acp-11-7185-2011, 2011

Schulz, M., de Leeuw, G., and Balkanski, Y.: Sea-salt aerosol source functions and emissions, in: Emission of Atmospheric Trace Compounds, edited by: Granier, C., Artaxo, P., and Reeves, C. E., Kluwer Acad., Norwell, Mass., 333-354, 2004.

Schulz, M., Prospero, J. M., Baker, A. R., Dentener, F., Ickes, L., Liss, P. S., Mahowald, N. M., Nickovic, S., Pérez, C., Rodríguez, S., Manmohan Sarin, M., Tegen, I., and Duce, R. A.: The atmospheric transport and deposition of mineral dust to the ocean: implications for research needs, Environ. Sci. Technol., 46, 10390-10404, doi:10.1021/es300073u, 2012.

Schuster, G. L., Vaughan, M., MacDonnell, D., Su, W., Winker, D., Dubovik, O., Lapyonok, T., and Trepte, C.: Comparison of CALIPSO aerosol optical depth retrievals to AERONET measurements, and a climatology for the lidar ratio of dust, Atmos. Chem. Phys., 12, 7431-7452, doi:10.5194/acp-12-7431-2012, 2012.

Shi, Y., Zhang, J., Reid, J. S., Holben, B., Hyer, E. J., and Curtis, C.: An analysis of the collection 5 MODIS over-ocean aerosol optical depth product for its implication in aerosol assimilation, Atmos. Chem. Phys., 11, 557-565, doi:10.5194/acp-11-557-2011, 2011.

Shi, Y., Zhang, J., Reid, J. S., Hyer, E. J., and Hsu, N. C.: Critical evaluation of the MODIS Deep Blue aerosol optical depth product for data assimilation over North Africa, Atmos. Meas. Tech., 6, 949-969, doi:10.5194/amt-6-949-2013, 2013.

Smirnov, A., Holben, B. N., Eck, T. F., Dubovik, O., and Slutsker, I.: Cloud screening and quality control algorithms for the AERONET database, Remote Sens. Environ., 73, 337-349, 2000.
Smirnov, A., Holben, B. N., Dubovik, O., O’Neill, N. T., Eck, T. F., Westphal, D. L., Goroch, A. K., Pietras, C., and Slutsker, I.: Atmospheric aerosol optical properties in the Persian Gulf, Atmos. Sci., 59, 620-634, 2002.

Smirnov, A., Holben, B. N., Slutsker, I., Giles, D. M., McClain, C. R., Eck, T. F., Sakerin, S. M., Macke, A., Croot, P., Zibordi, G., Quinn, P. K., Sciare, J., Kinne, S., Harvey, M., Smyth, T. J., Piketh, S., Zielinski, T., Proshutinsky, A., Goes, J. I., Nelson, N. B., Larouche, P., Radionov, V. F., Goloub, P., Krishna Moorthy, K., Matarrese, R., Robertson, E. J., and Jourdin, F.: Maritime aerosol network as a component of aerosol robotic network, J. Geophys. Res., 112, D06204, doi:10.1029/2008JD011257, 2009.

Smirnov, A., Holben, B. N., Giles, D. M., Slutsker, I., O’Neill, N. T., Eck, T. F., Macke, A., Croot, P., Courcoux, Y., Sakerin, S. M., Smyth, T. J., Zielinski, T., Zibordi, G., Goes, J. I., Harvey, M. J., Quinn, P. K., Nelson, N. B., Radionov, V. F., Duarte, C. M., Losno, R., Sciare, J., Voss, K. J., Kinne, S., Nalli, N. R., Joseph, E., Krishna Moorthy, K., Covert, D. S., Gulev, S. K., Milinevsky, G., Larouche, P., Belanger, S., Horne, E., Chin, M., Remer, L. A., Kahn, R. A., Reid, J. S., Schulz, M., Heald, C. L., Zhang, J., Lapina, K., Kleidman, R. G., Griesfeller, J., Gaitley, B. J., Tan, Q., and Diehl, T. L.: Maritime aerosol network as a component of AERONET - first results and comparison with global aerosol models and satellite retrievals, Atmos. Meas. Tech., 4, 583-597, doi:10.5194/amt-4-583-2011, 2011.

Smith, M. H. and Harrison, N. M.: The sea spray generation function, J. Aerosol Sci., 29, S189-S190, 1998.

Stammes, P. and Noordhoek, R.: OMI Algorithm Theoretical Basis Document Volume III: Clouds, Aerosols, and Surface UV Irradiance, Tech. Rep. ATBD-OMI-03, Version 2.0, available at: http://www.knmi.nl/omi/documents/data/OMI_ATBD_ Volume_3_V2.pdf (last access: 4 November 2014), KNMI, De Bilt, The Netherlands, 2002.

Stefanski, R. and Sivakumar, M. V. K.: Impacts of Sand and Dust Storms on Agriculture and Potential Agricultural Applications of a SDSWS, IOP C. Ser. Earth Env., 7, 012016, doi:10.1088/17551307/7/1/012016, 2009.

Sultan, B., Labadi, K., Guegan, J. F., and Janicot, S.: Climate drives the meningitis epidemics onset in West Africa, PLoS Med., 2, 43-49, 2005.

Tanré, D., Kaufman, Y. J., Herman, M., and Mattoo, S.: Remote sensing of aerosol properties over oceans using the MODIS/EOS spectral radiances, J. Geophys. Res., 102, 1697116988, doi:10.1029/96JD03437, 1997.

Taylor, K. E.: Summarizing multiple aspects of model performance in a single diagram, J. Geophys. Res., 106, 7183-7192, 2001.

Tegen, I.: Modeling the mineral dust aerosol cycle in the climate system, Quaternary Sci. Rev., 22, 1821-1834, 2003.

Tegen, I., Schepanski, K., and Heinold, B.: Comparing two years of Saharan dust source activation obtained by regional modelling and satellite observations, Atmos. Chem. Phys., 13, 2381-2390, doi:10.5194/acp-13-2381-2013, 2013.

Tesche, M., Ansmann, A., Müller, D., Althausen, D., Engelmann, R., Freudenthaler, V., Groß, S., and Esselborn, M.: Profiling of Saharan dust and biomass burning smoke with multiwavelength polarization Raman lidar at Cape Verde, Tellus B, 63, 649-676, doi:10.1111/j.1600-0889.2011.00548.X, 2011. 
Tesche, M., Wandinger, U., Ansmann, A., Althausen, D., Müller, D., and Omar, A. H.: Groundbased validation of CALIPSO observations of dust and smoke in the Cape Verde region, J. Geophys. Res., 118, 1-14, doi:10.1002/jgrd.50248, 2013.

Textor, C., Schulz, M., Guibert, S., Kinne, S., Balkanski, Y., Bauer, S., Berntsen, T., Berglen, T., Boucher, O., Chin, M., Dentener, F., Diehl, T., Easter, R., Feichter, H., Fillmore, D., Ghan, S., Ginoux, P., Gong, S., Grini, A., Hendricks, J., Horowitz, L., Huang, P., Isaksen, I., Iversen, I., Kloster, S., Koch, D., Kirkevåg, A., Kristjansson, J. E., Krol, M., Lauer, A., Lamarque, J. F., Liu, X., Montanaro, V., Myhre, G., Penner, J., Pitari, G., Reddy, S., Seland, $\varnothing$., Stier, P., Takemura, T., and Tie, X.: Analysis and quantification of the diversities of aerosol life cycles within AeroCom, Atmos. Chem. Phys., 6, 1777-1813, doi:10.5194/acp-6-1777-2006, 2006.

Thomson, M. C., Molesworth, A. M., Djingarey, M. H., Yameogo, K. R., Belanger, F., and Cuevas, L. E.: Potential of environmental models to predict meningitis epidemics in Africa, Trop. Med. Int. Health, 11, 781-788, 2006.

Todd, M. C., Washington, R., Martins, J. V., Dubovik, O., Lizcano, G., M'Bainayel, S., and Engelstaedter, S.: Mineral dust emission from the Bodélé Depression, northern Chad, during BoDEx 2005, J. Geophys. Res., 112, D06207, doi:10.1029/2006JD007170, 2007.

Torres, O., Bhartia, P. K., Sinyuk, A., Welton, E. J., and Holben, B.: Total Ozone Mapping Spectrometer measurements of aerosol absorption from space: comparison to SAFARI 2000 ground-based observations, J. Geophys. Res., 110, D10S18, doi:10.1029/2004JD004611, 2005.

Torres, O., Tanskanen, A., Veihelmann, B., Ahn, C., Braak, R., Bhartia, P. K., Veefkind, P., and Levelt, P.: Aerosols and surface UV products from Ozone Monitoring Instrument observations: an overview, J. Geophys. Res., 112, D24S47, doi:10.1029/2007JD008809, 2007.

Tompkins, A. M.: A Revised Cloud Scheme to Reduce the Sensitivity to Vertical Resolution, Tech. Memo. 0599, Res. Dep., Eur. Cent. for Medium-Range Weather Forecasts, Reading, UK, 25 pp., 2005.

Tsamalis, C., Chédin, A., Pelon, J., and Capelle, V.: The seasonal vertical distribution of the Saharan Air Layer and its modulation by the wind, Atmos. Chem. Phys., 13, 11235-11257, doi:10.5194/acp-13-11235-2013, 2013.

Vali, G.: Atmospheric ice nucleation: a review, J. Rech. Atmos., 19, 105-112, 1985.

van der Werf, G. R., Randerson, J. T., Giglio, L., Collatz, G. J., Mu, M., Kasibhatla, P. S., Morton, D. C., DeFries, R. S., Jin, Y., and van Leeuwen, T. T.: Global fire emissions and the contribution of deforestation, savanna, forest, agricultural, and peat fires (19972009), Atmos. Chem. Phys., 10, 11707-11735, doi:10.5194/acp10-11707-2010, 2010.
Vaughan, M. A., Powell, K. A., Kuehn, R. E., Young, S. A., Winker, D. M., Hostetler, C. A., Hunt, W. H., Liu, Z., McGill, M. J., and Getzewich, B. J.: Fully automated detection of cloudand aerosol layers in the CALIPSO lidar measurements, J. Atmos. Ocean. Tech., 26, 2034-2050, doi:10.1175/2009JTECHA1228.1, 2009.

Viana, M., Querol, X., Alastuey, A., Cuevas, E., and Rodríguez, S.: Influence of African dust on the levels of atmospheric particulates in the Canary Islands air quality network, Atmos. Environ., 36, 5861-5875, 2002.

Wang, J., Xia, X., Wang, P., and Christopher, S. A.: Diurnal variability of dust aerosol optical thickness and Angström exponent over dust source regions in China, Geophys. Res. Lett., 31, L08107, doi:10.1029/2004GL019580, 2004.

Wang, Y. Q., Zhang, X. Y., Gong, S. L., Zhou, C. H., Hu, X. Q., Liu, H. L., Niu, T., and Yang, Y. Q.: Surface observation of sand and dust storm in East Asia and its application in CUACE/Dust, Atmos. Chem. Phys., 8, 545-553, doi:10.5194/acp-8-545-2008, 2008.

Welton, E. J., Campbell, J. R., Berkoff, T. A., Valencia, S., Spinhime, J. D., Holben, B., and Tsay, S. C.: The NASA MicroPulse Lidar NETWORK (MPLNET): Co-Location of Lidars with Aeronet Sunphotometers and Related Earth Science Applications, 85th AMS Annual Meeting, American Meteorological Society, San Diego, 9-13 January 2005, 5165-5169, 2005.

Westphal, D. L., Curtis, C. A., Liu, M., and Walker, A. L.: Operational aerosol and dust storm forecasting, IOP C. Ser. Earth Env., 7, 012007, doi:10.1088/1755-1307/7/1/012007, 2009.

WHO: WHO Air Quality Guidelines Global Update 2005, Bonn, Germany, World Health Organization, WHO Regional Office for Europe, Copenhagen, Denmark, 2006.

Winker, D. M., Vaughan, M. A. Omar, A., Hu, Y., Powell, K. A., Liu, Z., Hunt, W. H., and Young, S. A.: Overview of the CALIPSO mission and CALIOP data processing algorithms, J. Atmos. Ocean. Tech., 26, 2310-2323, doi:10.1175/2009JTECHA1281.1, 2009.

Young, S. A. and Vaughan, M. A.: The retrieval of profiles of particulate extinction from Cloud-Aerosol Lidar Infrared Pathfinder Satellite Observations (CALIPSO) data: algorithm description, J. Atmos. Ocean. Tech., 26, 1105-1119, doi:10.1175/2008JTECHA1221.1,2009.

Zhou, Z., Dionisio, K. L., Verissimo, T. G., Kerr, A. S., Coull, B., Arku, R. A., Koutrakis, P., Spengler, J. D., Hughes, A. F., Vallarino, J., Agyei-Mensah, S., and Ezzati, M.: Chemical composition and sources of particle pollution in affluent and poor neighborhoods of Accra, Ghana, Environ. Res. Lett., 8, 044025, doi:10.1088/1748-9326/8/4/044025, 2013. 